\title{
MIDDLE STYX ELECTROMAGNETIC, MAGNETIC, AND RADIOMETRIC AIRBORNE GEOPHYSICAL SURVEY DATA COMPILATION
}

Burns, L.E., Graham, G.R.C., Emond, A.M., Barefoot, J.D., CGG, and Fugro GeoServices, Inc.

Geophysical Report 2019-10

2019

STATE OF ALASKA

DEPARTMENT OF NATURAL RESOURCES

DIVISION OF GEOLOGICAL \& GEOPHYSICAL SURVEYS
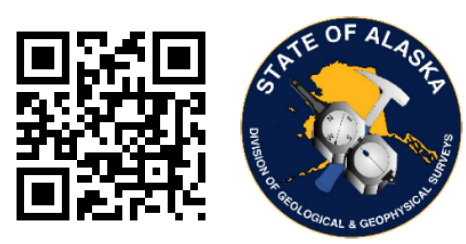
STATE OF ALASKA

Michael J. Dunleavy, Governor

DEPARTMENT OF NATURAL RESOURCES

Corri A. Feige, Commissioner

\title{
DIVISION OF GEOLOGICAL \& GEOPHYSICAL SURVEYS
}

Steve Masterman, State Geologist \& Director

Publications produced by the Division of Geological \& Geophysical Surveys are available to download from the DGGS website (dggs.alaska.gov). Publications on hard-copy or digital media can be examined or purchased in the Fairbanks office:

\author{
Alaska Division of Geological \& Geophysical Surveys (DGGS) \\ 3354 College Road | Fairbanks, Alaska 99709-3707 \\ Phone: 907.451 .5010 | Fax 907.451.5050 \\ dggspubs@alaska.gov $\mid$ dggs.alaska.gov
}

DGGS publications are also available at:

Alaska State Library, Historical

Collections \& Talking Book Center

395 Whittier Street

Juneau, Alaska 99801

Alaska Resource Library and

Information Services (ARLIS)

3150 C Street, Suite 100

Anchorage, Alaska 99503

\section{Suggested citation:}

Burns, L.E., Graham, G.R.C., Emond, A.M., Barefoot, J.D., CGG, and Fugro GeoServices, Inc., 2019, Middle Styx electromagnetic, magnetic, and radiometric airborne geophysical survey data compilation: Alaska Division of Geological \& Geophysical Surveys Geophysical Report 2019-10. http://doi.org/10.14509/30188
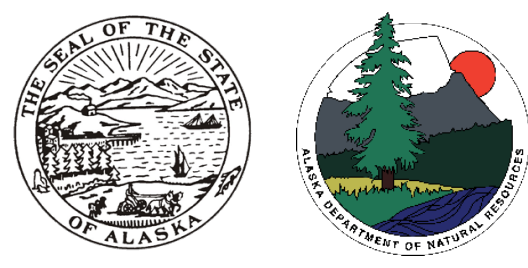


\section{MIDDLE STYX ELECTROMAGNETIC, MAGNETIC, AND RADIOMETRIC AIRBORNE GEOPHYSICAL SURVEY DATA COMPILATION}

Burns, L.E. ', Graham, G.R.C. ', Emond, A.M.' ', Barefoot, J.D. ', CGG, and Fugro GeoServices, Inc.

\section{ABSTRACT}

This geophysical survey is located about 150 kilometers northwest of Anchorage, Alaska in the upper South Fork of the Kuskokwim River drainage and south of Rainy Pass in south-central Alaska. The survey is in or near the Yentna, Redoubt, and McGrath mining districts. Frequency domain electromagnetic, magnetic, and radiometric data were collected with the DIGHEMV system from September 12th to November 3rd, 2012 and June 29th to September 27th, 2013. A total of 1154.9 line kilometers were collected covering 406.38 square kilometers. Line spacing was 400 meters $(\mathrm{m})$. Data were collected $30 \mathrm{~m}$ above the ground surface from a helicopter towed sensor platform ("bird") on a $30 \mathrm{~m}$ long line.

\section{PURPOSE}

This airborne geophysical survey is part of a program to acquire data on Alaska's most promising mineral belts and districts. The information acquired is aimed at catalyzing new private sector exploration, discovery, and ultimate development and production. The primary goal of the Middle Styx project is to delineate prospective mineral zones and to support detailed geologic mapping. Prospects of several different types occur in the region surrounding the survey area, including polymetallic veins, epithermal veins, and porphyry copper deposits.

\section{SURVEY OVERVIEW DESCRIPTION}

This document provides an overview of the survey and includes text and figures of select primary and derivative products of this survey. A table of digital data packages available for download is provided to assist users in data selection. For reference a catalog of the available maps is presented in reduced resolution. Please consult the metadata, project report, and digital data packages for more information and data.

\section{ACKNOWLEDGMENTS}

Funding was provided by the Alaska State Legislature as part of the DGGS Airborne Geophysical/Geological Mineral Inventory (AGGMI) program and the Alaska Strategic and Critical Minerals Assessment Capital Improvement Project (SCMA).

\footnotetext{
${ }^{1}$ Alaska Division of Geological \& Geophysical Surveys, 3354 College Road, Fairbanks, Alaska 99709-3707
} 


\begin{tabular}{|c|c|c|}
\hline Data Type & Provider & Description \\
\hline ascii_data & contractor & ASCII format line data, other ASCII data \\
\hline databases_geosoft & contractor & $\begin{array}{l}\text { Geosoft format database of final line data, other } \\
\text { Geosoft format databases }\end{array}$ \\
\hline documents & contractor and DGGS & $\begin{array}{l}\text { Project and field reports, survey background } \\
\text { information, gridded data explanations, other } \\
\text { documentation }\end{array}$ \\
\hline grids_ermapper & contractor & $\begin{array}{l}\text { Geographically registered gridded data, ER Mapper } \\
\text { ERS format }\end{array}$ \\
\hline grids_geosoft & contractor and DGGS & $\begin{array}{l}\text { Geosoft-format grids, these grids can be viewed in } \\
\text { ESRI ArcMap using a free plugin from Geosoft or the } \\
\text { free viewer available from Geosoft }\end{array}$ \\
\hline images_registered & DGGS & GeoTiff format images of all gridded data \\
\hline $\mathrm{kmz}$ & DGGS & $\begin{array}{l}\text { keyhole markup language }(\mathrm{kml}) \mathrm{kmz} \text { archive files of } \\
\text { project data. Viewable in Google Earth and other } \\
\text { compatible programs }\end{array}$ \\
\hline maps_pdf_format & contractor & Printable maps in pdf format \\
\hline maps_prn_format & contractor & $\begin{array}{l}\text { Printable maps in HPGL/2 printer file format with } \\
\text { extension .prn }\end{array}$ \\
\hline profiles_stacked & contractor & $\begin{array}{l}\text { Distance-based profiles of the digitally recorded } \\
\text { geophysical data are generated and plotted at an } \\
\text { appropriate scale. The profiles display } \\
\text { electromagnetic anomalies with their respective } \\
\text { interpretive symbols. Printable in pdf format }\end{array}$ \\
\hline vector_data & contractor and DGGS & $\begin{array}{l}\text { Line path, data contours, and survey boundary in } \\
\text { ESRI shapefile (SHP) format, ESRI Geodatabase } \\
\text { format, and/or AutoCAD dxf format }\end{array}$ \\
\hline video_flightpath & contractor & Survey flight path downward facing video \\
\hline
\end{tabular}




\section{REFERENCES}

Akima, H., 1970, A new method of interpolation and smooth curve fitting based on local procedures: Journal of the Association of Computing Machinery, v. 17, n. 4, p. 589-602.

Burns, L.E., Fugro Airborne Surveys Corp., and Fugro GeoServices, Inc., 2013, Middle Styx survey area: Airborne magnetic, electromagnetic, and radiometric data in line (point), grid, vector, and map formats, Lime Hills and Tyonek quadrangles, southcentral Alaska: Alaska Division of Geological \& Geophysical Surveys Geophysical Report 2013-2, scale 1:63,360, 1 DVD. http://doi.org/10.14509/25419

CGG, and Fugro GeoServices, Inc., 2015, Farewell and Middle Styx survey areas: Project report, interpretation maps, EM anomalies, stacked multi-channel profiles, and other products of the airborne geophysical surveys, parts of the McGrath, Lime Hills, and Tyonek quadrangles, south-central Alaska: Alaska Division of Geological \& Geophysical Surveys Geophysical Report 2014-4, 22 sheets. http://doi.org/10.14509/29349 


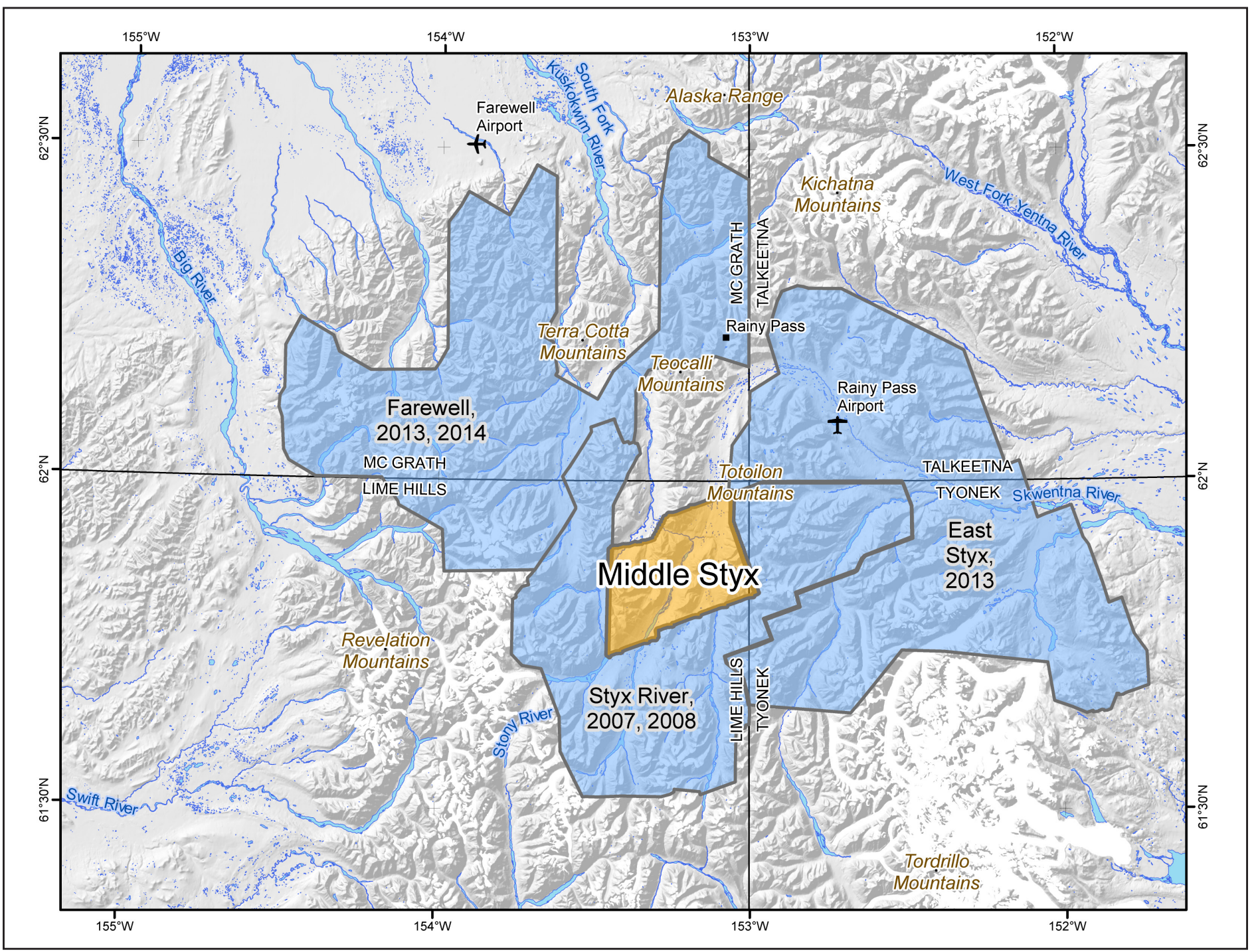

Figure 1. Middle Styx electromagnetic and magnetic airborne geophysical survey location shown in southcentral Alaska (right). Middle Styx survey area shown with adjacent DGGS geophysical surveys, landmarks, relevant 1:250,000-scale quadrangle boundaries, mountain ranges, rivers, glaciers, and elevation hillshade.

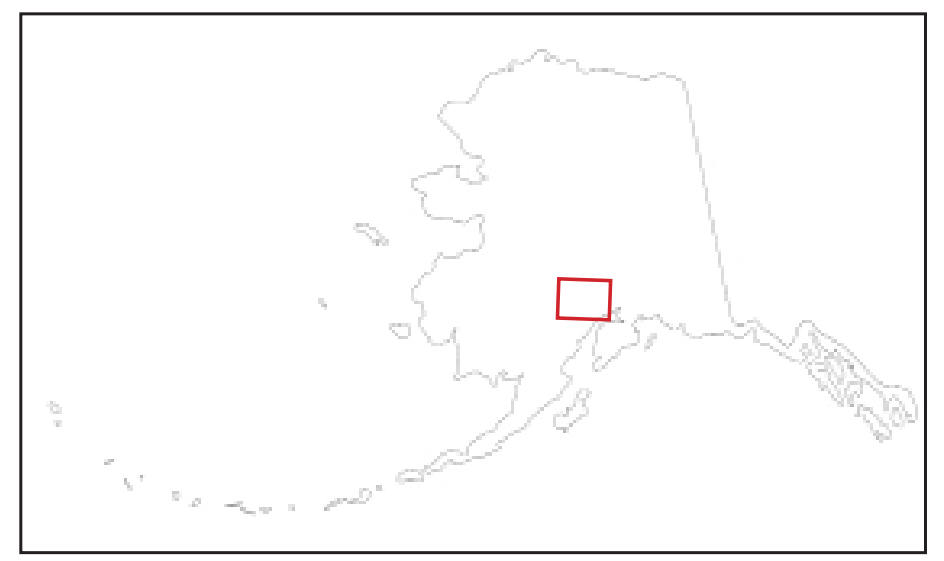




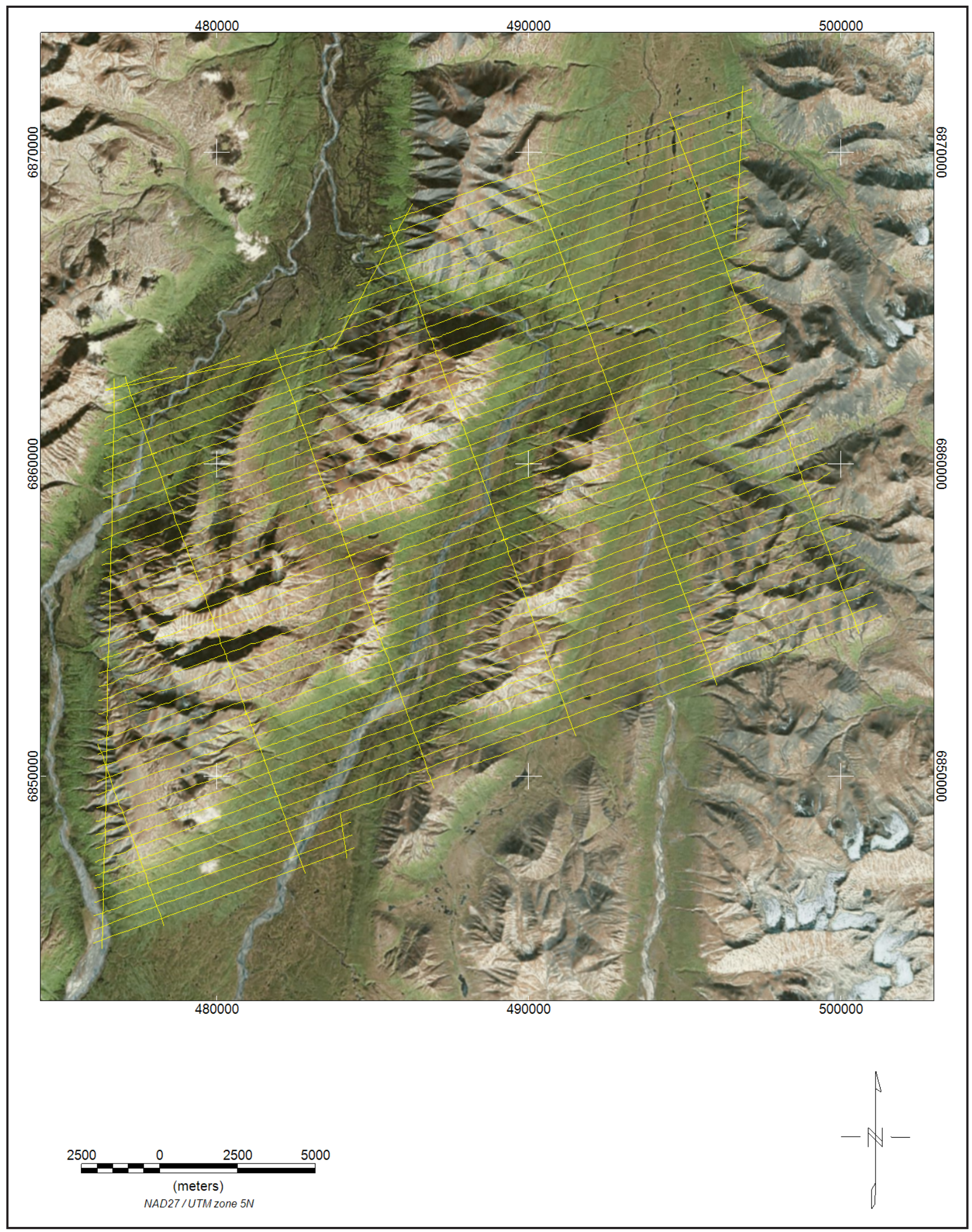

Figure 2. Flight path with orthometric image. 


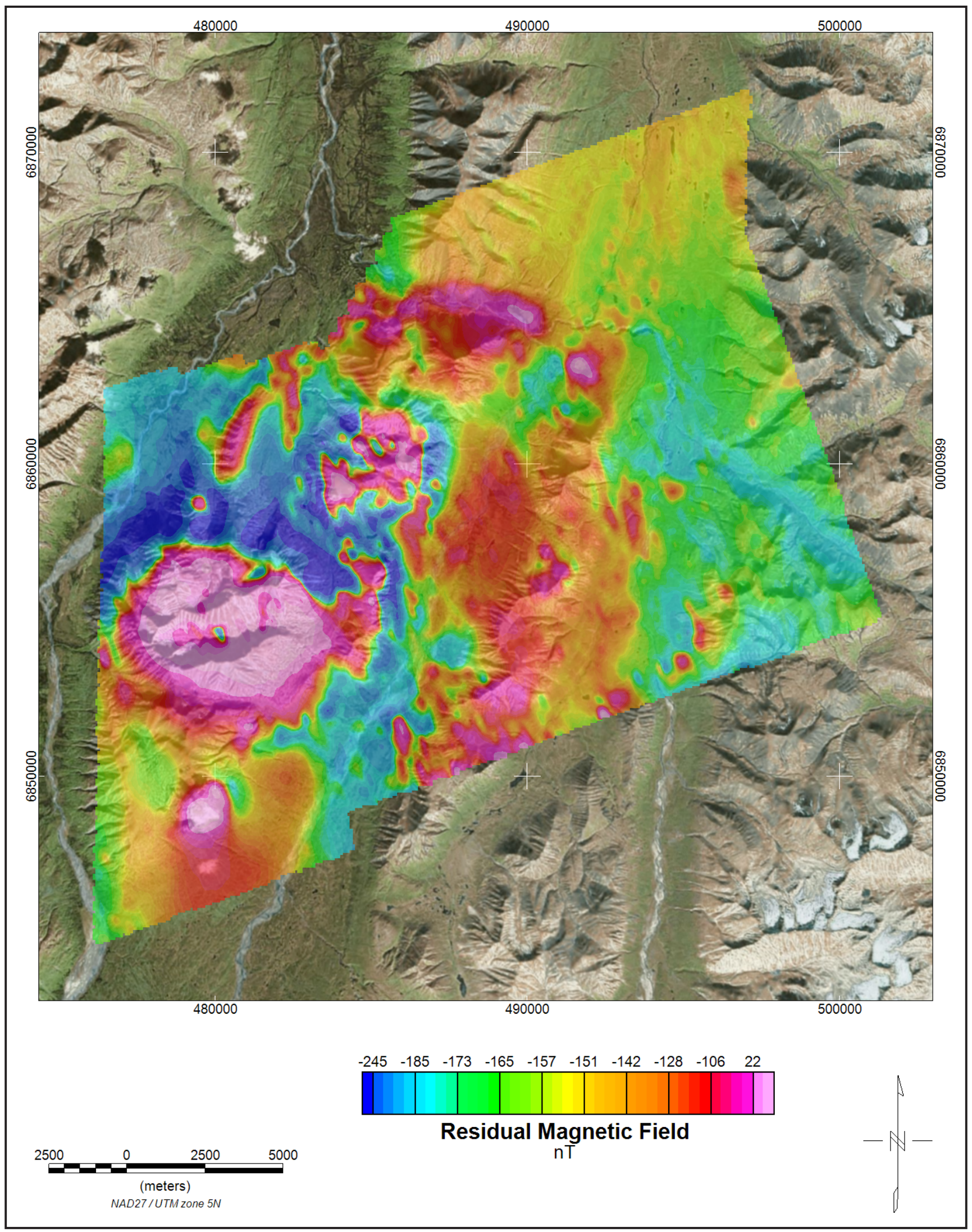

Figure 3. The magnetic total field data were created using digitally recorded data from a Fugro D1344 magnetometer with a Scintrex CS3 cesium sensor. Data were collected at a sampling interval of 0.1 seconds. The magnetic data were (1) corrected for diurnal variations by subtracting the digitally recorded base station magnetic data, (2) IGRF corrected (IGRF model 2010, updated for date of flight and altimeter variations), (3) leveled to the tie line data, and (4) interpolated onto a regular 80 m grid using a modified Akima (1970) technique. 


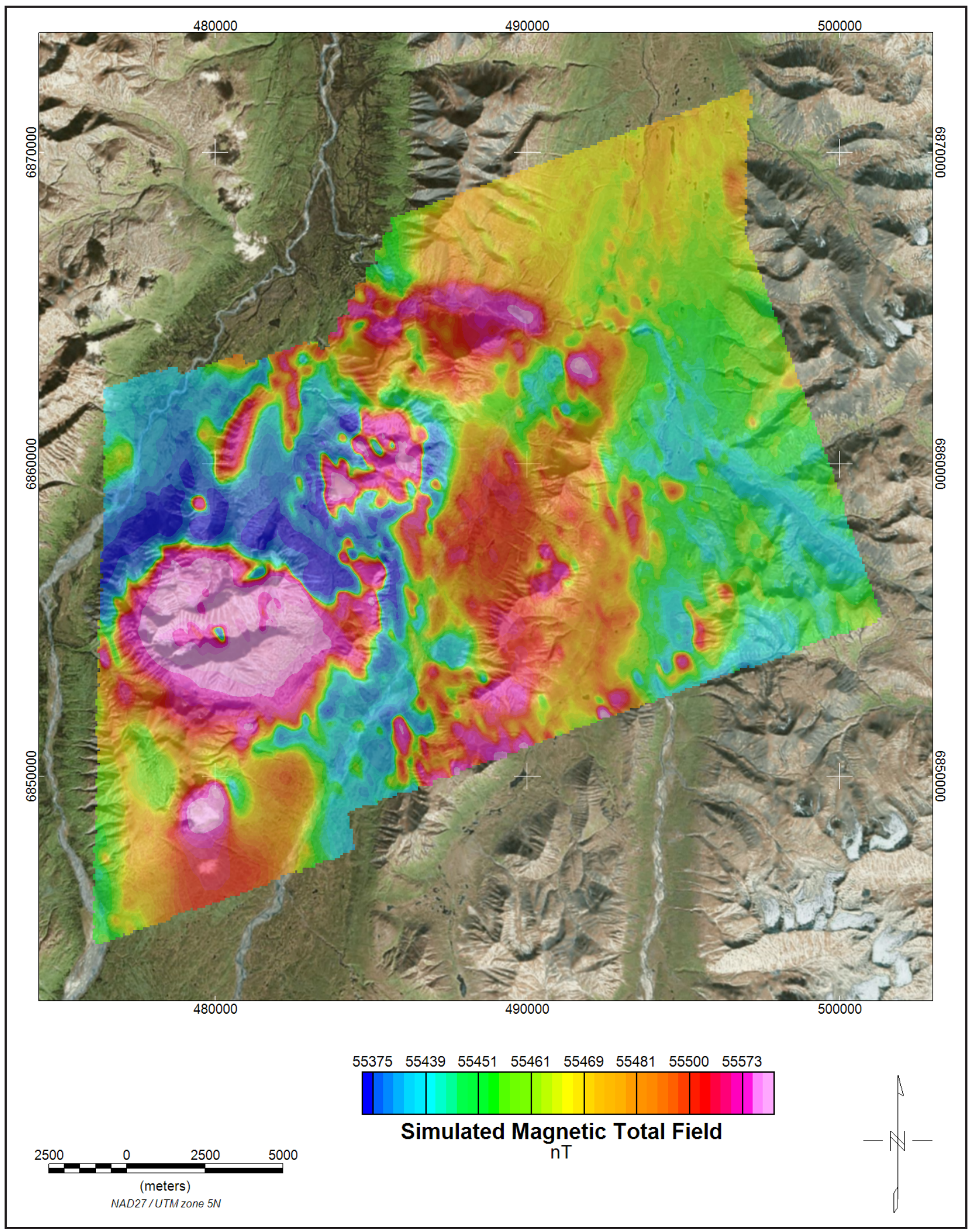

Figure 4. The simulated magnetic total field data were created using digitally recorded data from a Fugro D1344 magnetometer with a Scintrex CS3 cesium sensor. Data were collected at a sampling interval of 0.1 seconds. The magnetic data were (1) corrected for diurnal variations by subtracting the digitally recorded base station magnetic data, (2) IGRF corrected (IGRF model 2010, updated for date of flight and altimeter variations), (3) leveled to the tie line data, (4) a constant value of approximately 55,000 nT was added to all data, and (5) interpolated onto a regular $80 \mathrm{~m}$ grid using a modified Akima (1970) technique. 


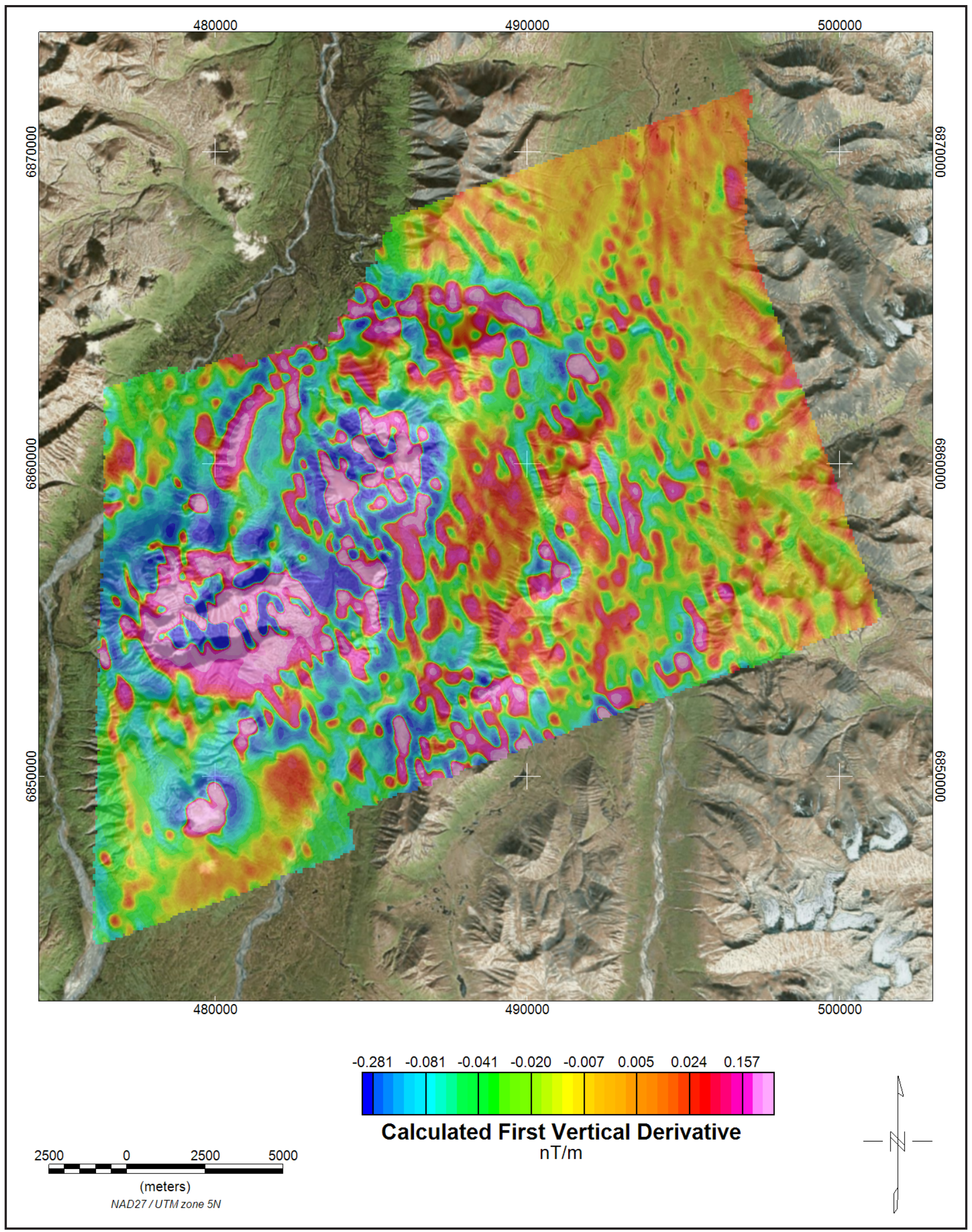

Figure 5. The first vertical derivative grid was calculated from the diurnally-corrected, IGRF-corrected total magnetic field grid using a FFT base frequency domain filtering algorithm. The resulting first vertical derivative grid provides better definition and resolution of near- surface magnetic units and helps to identify weak magnetic features that may not be evident on the total field data. 


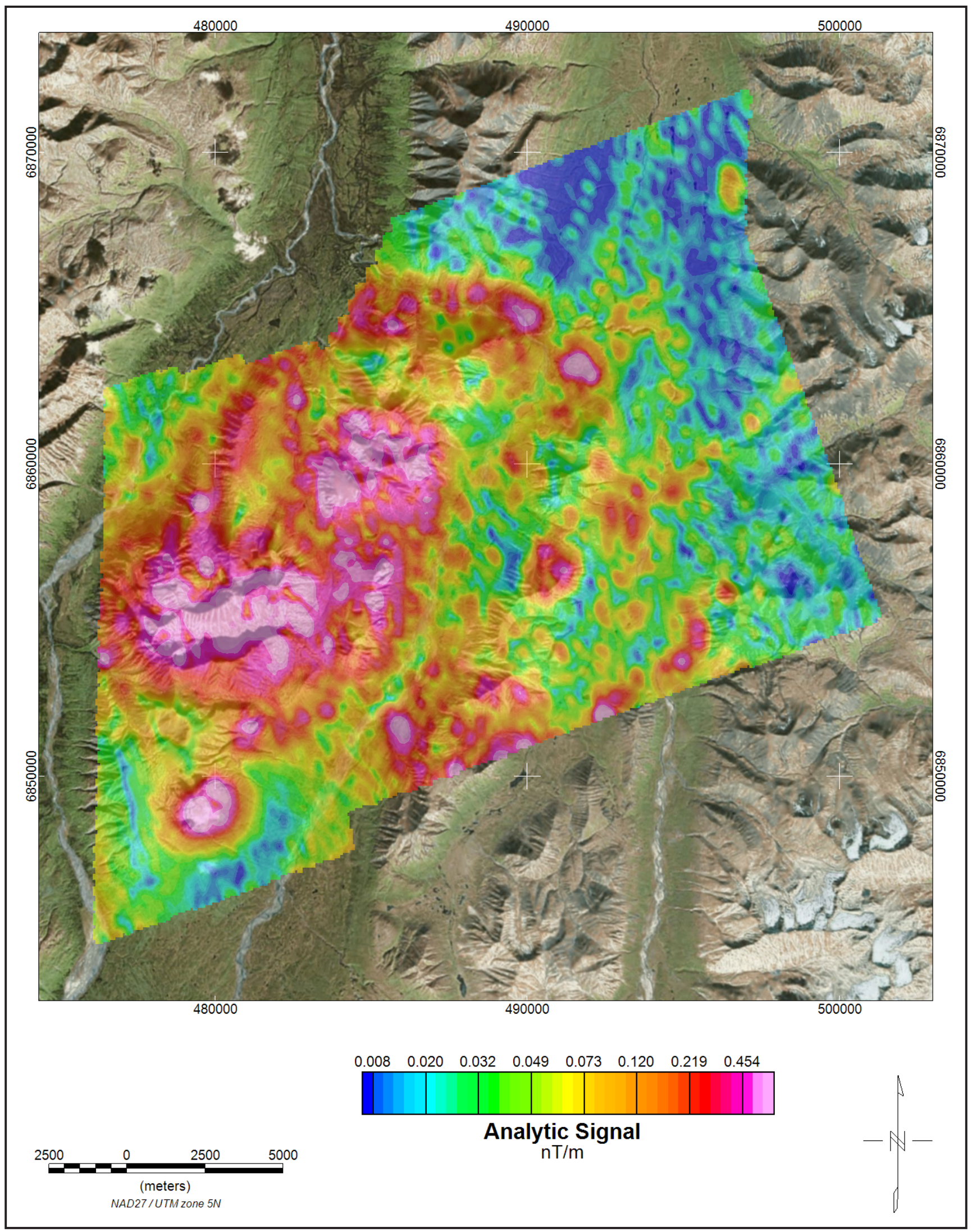

Figure 6. Analytic signal is the total amplitude of all directions of magnetic gradient calculated from the sum of the squares of the three orthogonal gradients. Mapped highs in the calculated analytic signal of magnetic parameter locate the anomalous source body edges and corners (such as contacts, fault/shearzones, etc.). Analytic signal maxima are located directly over faults and contacts, regardless of structural dip, and independent of the direction of the induced and/or remanent magnetizations. 


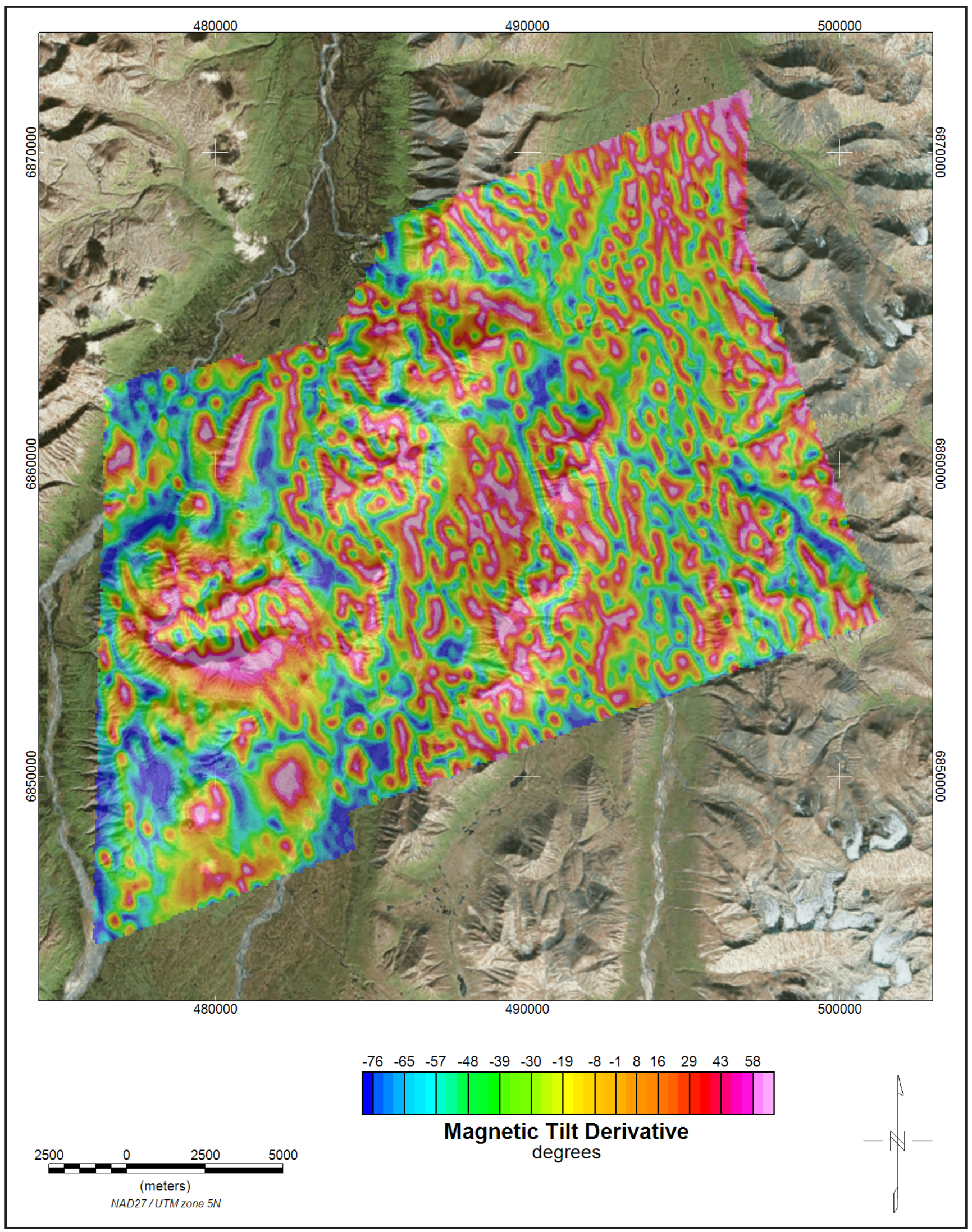

Figure 7. The tilt derivative is the angle between the horizontal gradient and the total gradient, which is useful for identifying the depth and type of source. The tilt angle is positive over the source, crosses through zero at, or near, the edge of a vertical sided source, and is negative outside the source region. It has the added advantage of responding equally well to shallow and deep sources and is able to resolve deeper sources that may be masked by larger responses from shallower sources. 


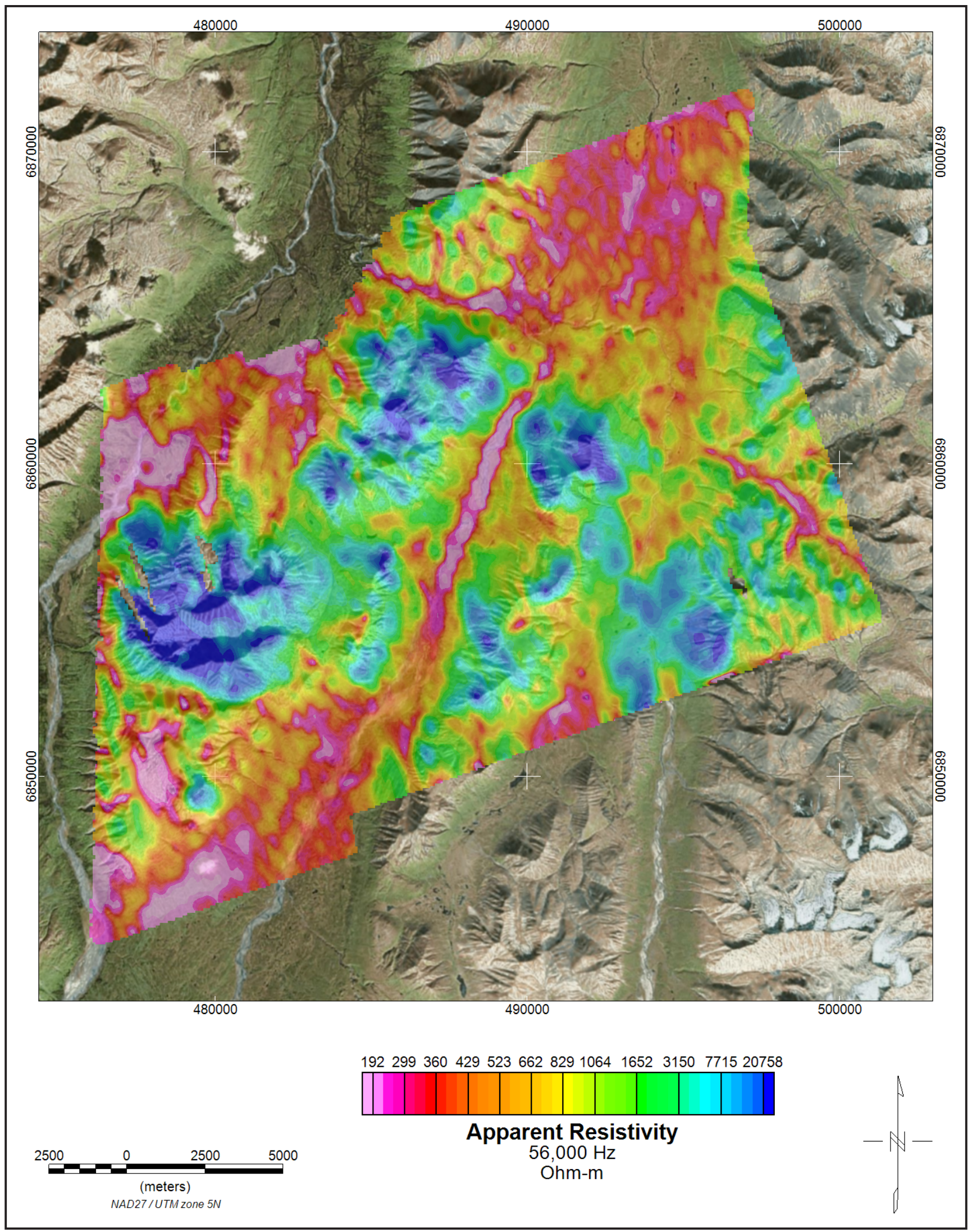

Figure 8. The DIGHEMv EM system measured inphase and quadrature components at five frequencies. Two vertical coaxial coil-pairs operated at 1000 and $5500 \mathrm{~Hz}$ while three horizontal coplanar coil-pairs operated at 900, 7,200 and 56,000 Hz. EM data were sampled at 0.1 second intervals. The EM system responds to bedrock conductors, conductive overburden, and cultural sources. Apparent resistivity is generated from the inphase and quadrature component of the coplanar $56,000 \mathrm{~Hz}$ using the pseudo-layer half space model. The data were interpolated onto a regular $80 \mathrm{~m}$ grid using a modified Akima (1970) technique. 


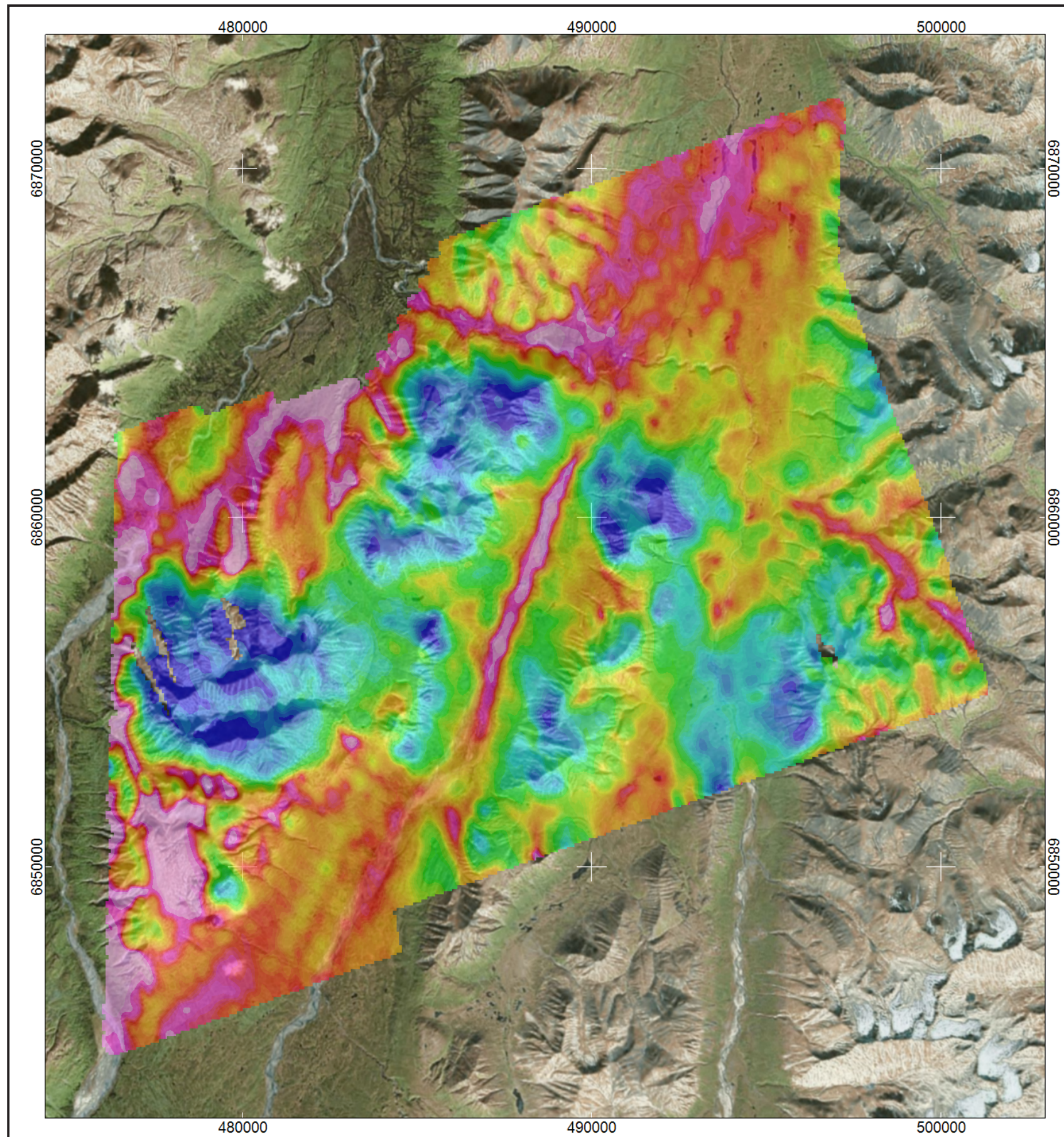

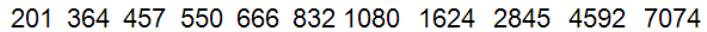

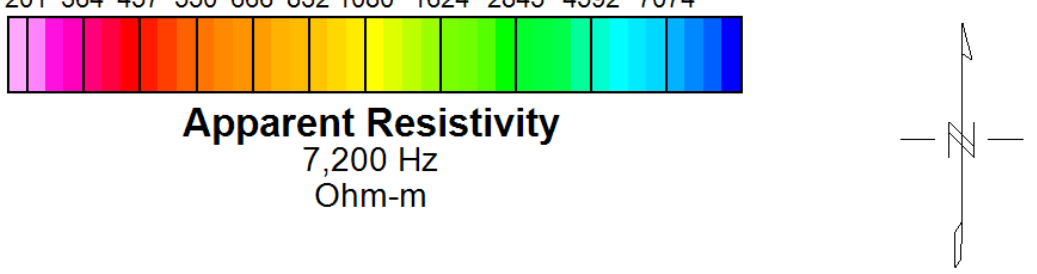

Figure 9. The DIGHEM ${ }^{\vee}$ EM system measured inphase and quadrature components at five frequencies. Two vertical coaxial coil-pairs operated at 1000 and $5500 \mathrm{~Hz}$ while three horizontal coplanar coil-pairs operated at 900, 7,200 and 56,000 Hz. EM data were sampled at 0.1 second intervals. The EM system responds to bedrock conductors, conductive overburden, and cultural sources. Apparent resistivity is generated from the inphase and quadrature component of the coplanar $7,200 \mathrm{~Hz}$ using the pseudo-layer half space model. The data were interpolated onto a regular $80 \mathrm{~m}$ grid using a modified Akima (1970) technique. 


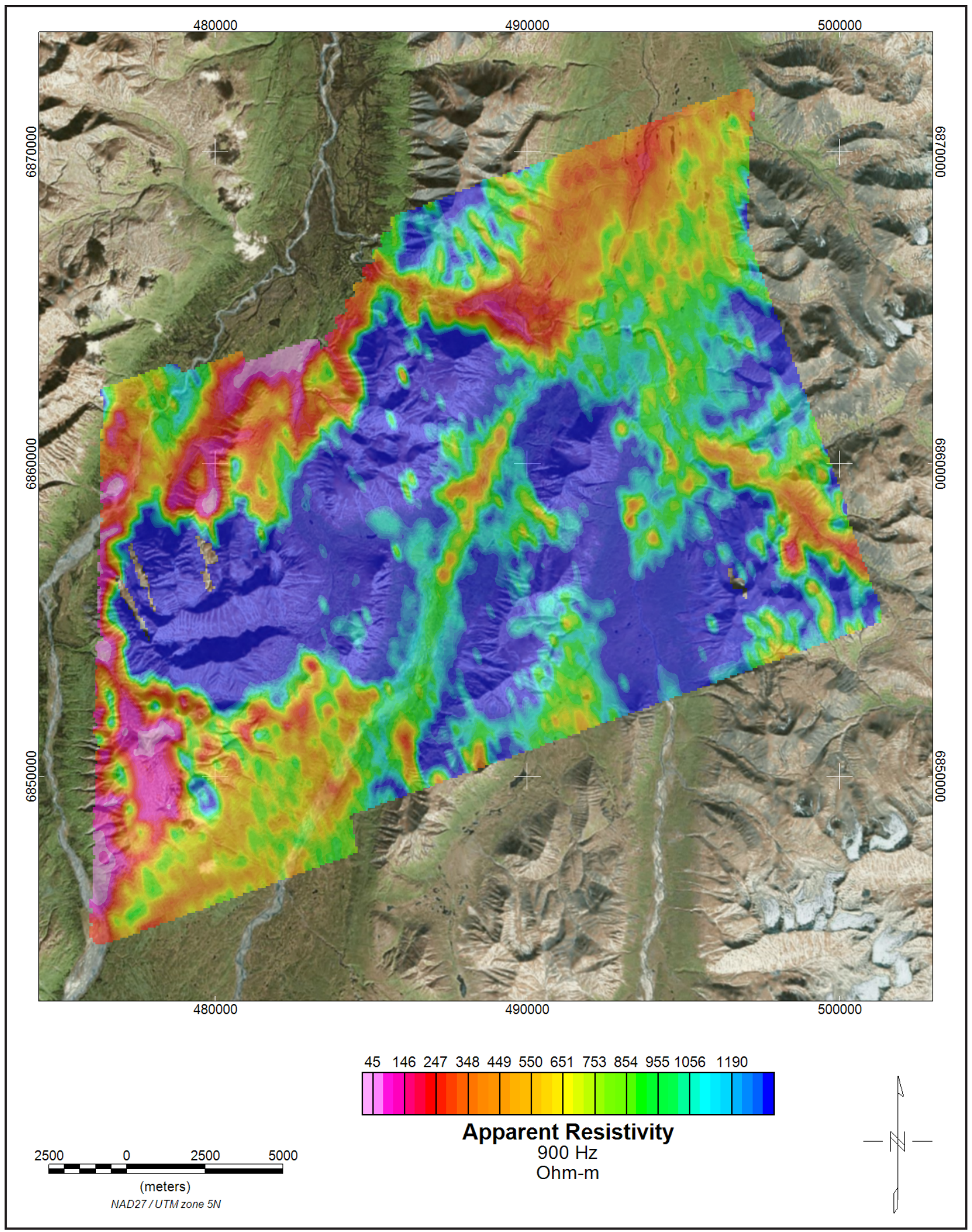

Figure 10. The DIGHEM ${ }^{\vee} E M$ system measured inphase and quadrature components at five frequencies. Two vertical coaxial coilpairs operated at 1000 and $5500 \mathrm{~Hz}$ while three horizontal coplanar coil-pairs operated at 900, 7,200 and 56,000 Hz. EM data were sampled at 0.1 second intervals. The EM system responds to bedrock conductors, conductive overburden, and cultural sources. Apparent resistivity is generated from the inphase and quadrature component of the coplanar $900 \mathrm{~Hz}$ using the pseudo-layer half space model. The data were interpolated onto a regular $80 \mathrm{~m}$ grid using a modified Akima (1970) technique. 


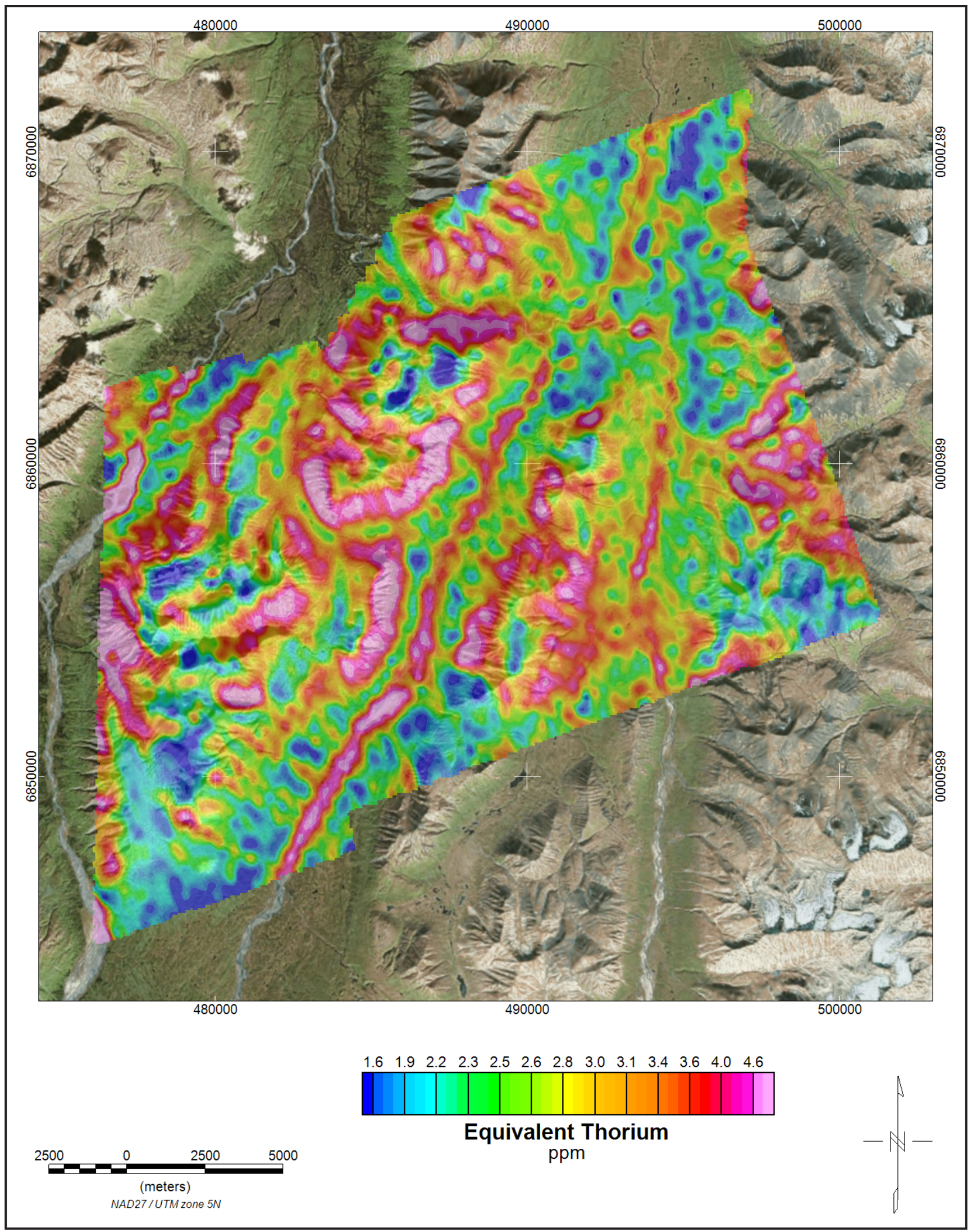

Figure 11. The gamma-ray spectrometry data were recorded at a 1.0 second sample rate into a 256 channel main and radon spectra using a Radiation Solutions RS-500 gamma-ray spectrometer. After removal of the background, the data were corrected for spectral interferences, changes in temperature, pressure, and departures from the planned survey elevation of $60 \mathrm{~m}$. The data were then converted to standard concentration units which were interpolated to a $100 \mathrm{~m}$ grid using a minimum curvature technique. 


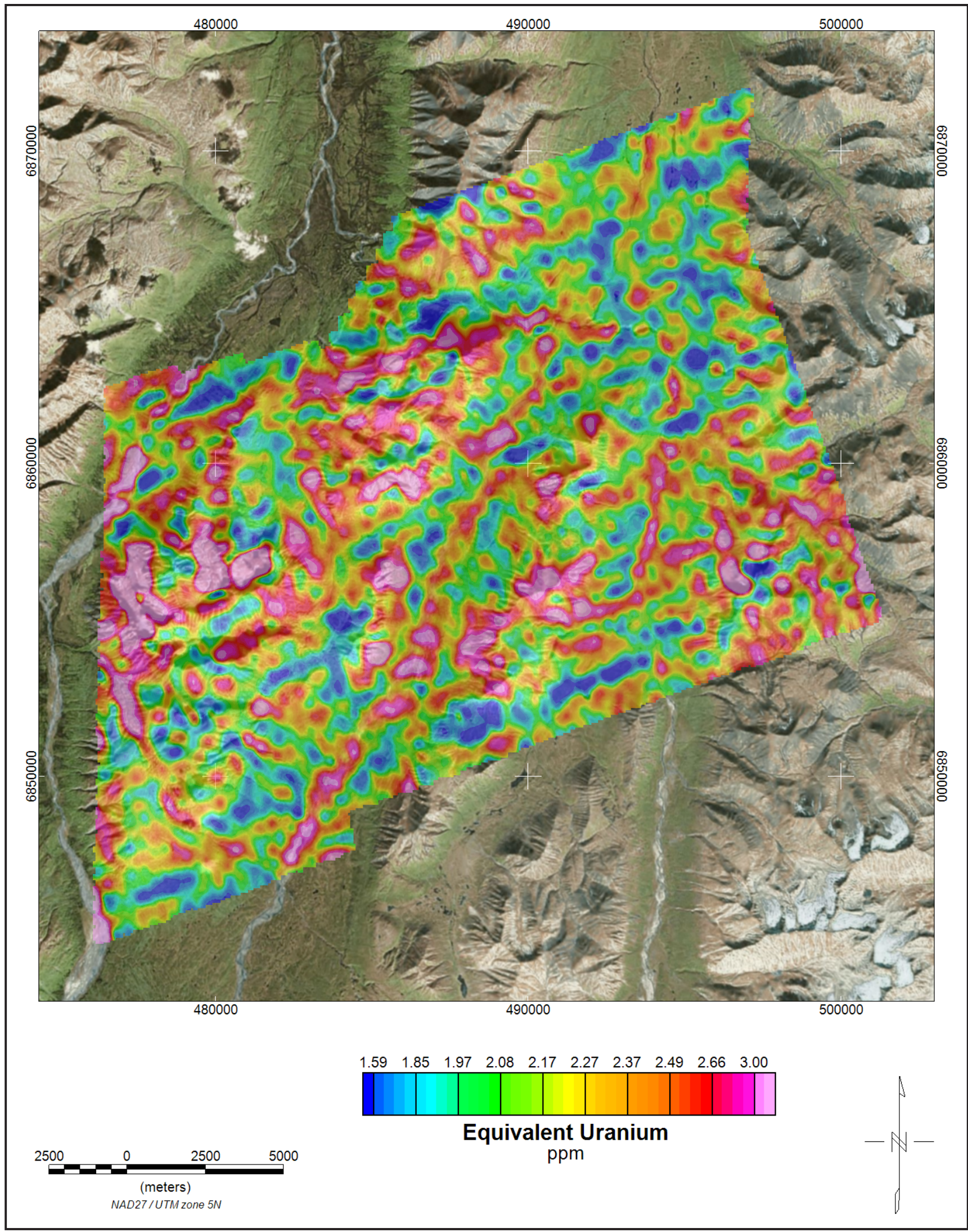

Figure 12. The gamma-ray spectrometry data were recorded at a 1.0 second sample rate into a 256 channel main and radon spectra using a Radiation Solutions RS-500 gamma-ray spectrometer. After removal of the background, the data were corrected for spectral interferences, changes in temperature, pressure, and departures from the planned survey elevation of $60 \mathrm{~m}$. The data were then converted to standard concentration units which were interpolated to a $100 \mathrm{~m}$ grid using a minimum curvature technique. 


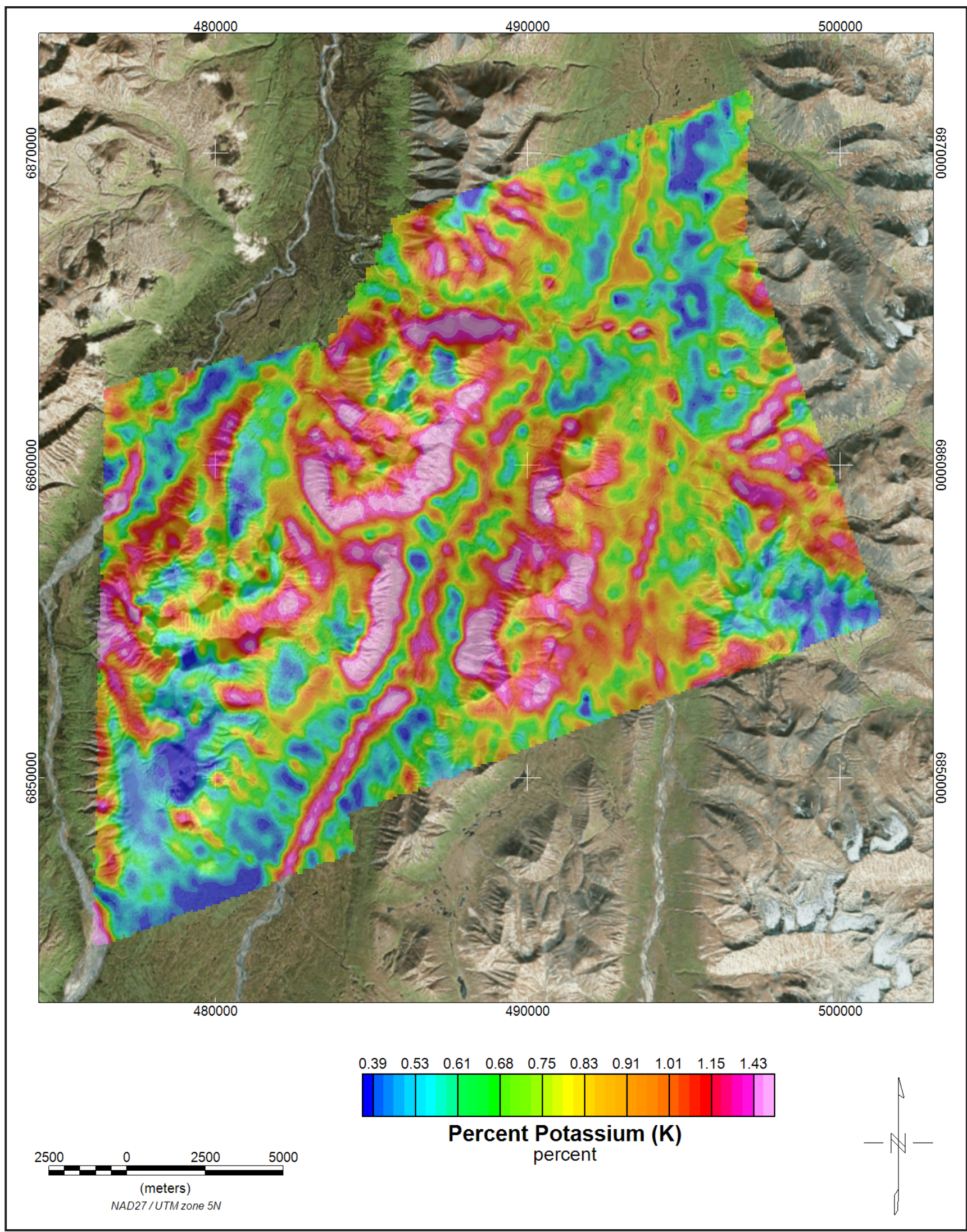

Figure 13. The gamma-ray spectrometry data were recorded at a 1.0 second sample rate into a 256 channel main and radon spectra using a Radiation Solutions RS-500 gamma-ray spectrometer. After removal of the background, the data were corrected for spectral interferences, changes in temperature, pressure, and departures from the planned survey elevation of $60 \mathrm{~m}$. The data were then converted to standard concentration units which were interpolated to a $100 \mathrm{~m}$ grid using a minimum curvature technique. 


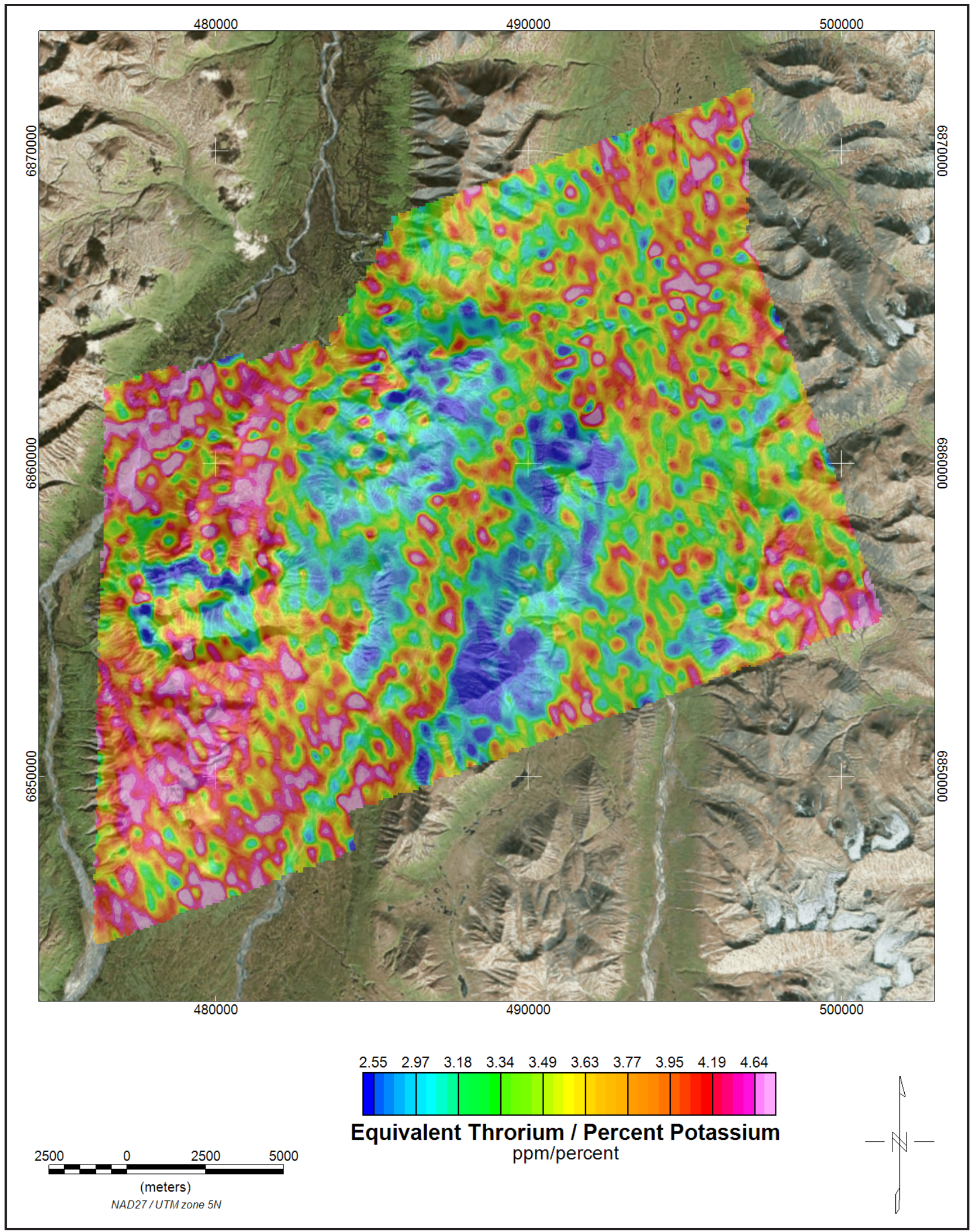

Figure 14. The gamma-ray spectrometry data were recorded at a 1.0 second sample rate into a 256 channel main and radon spectra using a Radiation Solutions RS-500 gamma-ray spectrometer. After removal of the background, the data were corrected for spectral interferences, changes in temperature, pressure, and departures from the planned survey elevation of $60 \mathrm{~m}$. The data were then converted to standard concentration units which were interpolated to a $100 \mathrm{~m}$ grid using a minimum curvature technique. 


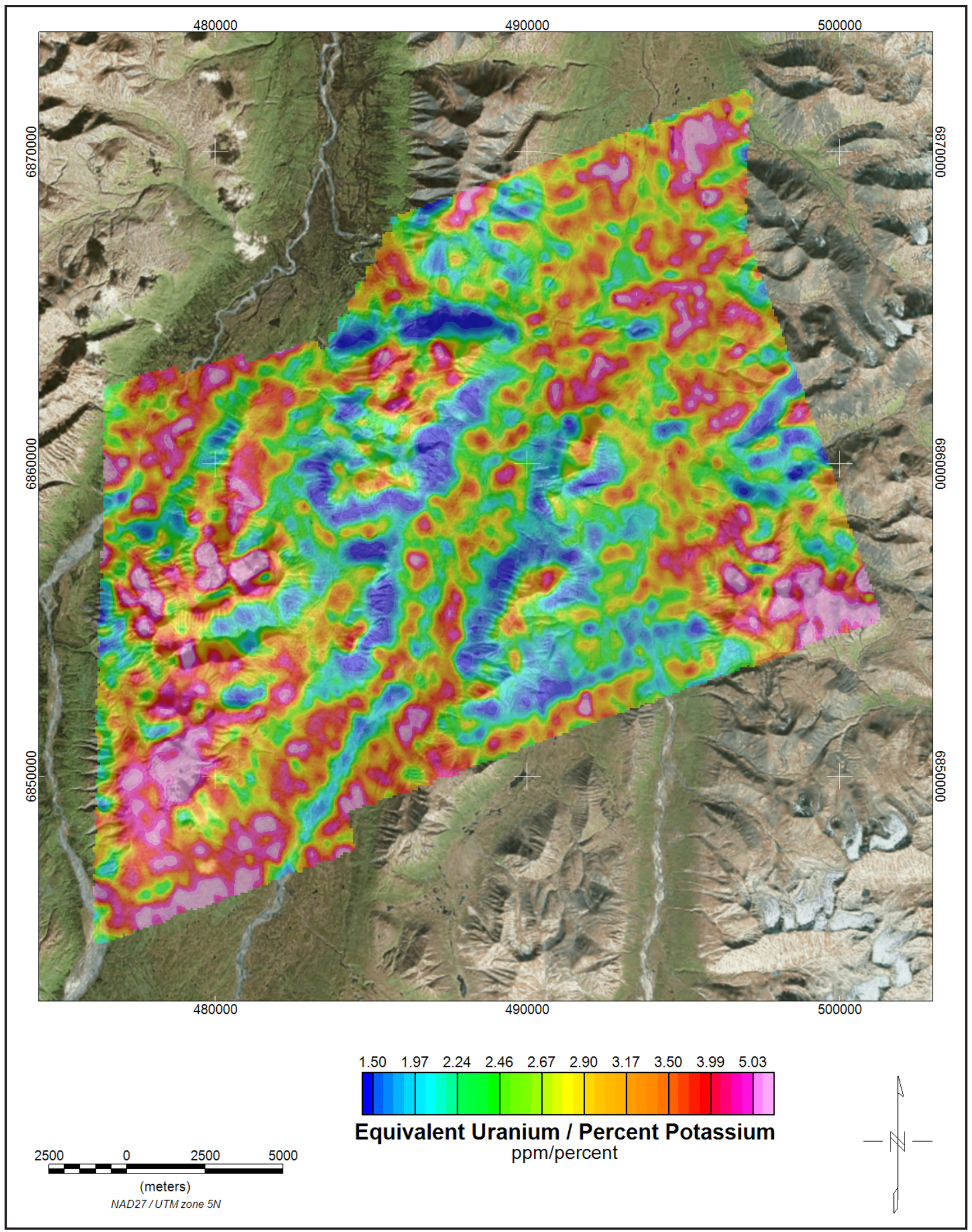

Figure 15. The gamma-ray spectrometry data were recorded at a 1.0 second sample rate into a 256 channel main and radon spectra using a Radiation Solutions RS-500 gamma-ray spectrometer. After removal of the background, the data were corrected for spectral interferences, changes in temperature, pressure, and departures from the planned survey elevation of $60 \mathrm{~m}$. The data were then converted to standard concentration units which were interpolated to a $100 \mathrm{~m}$ grid using a minimum curvature technique. 


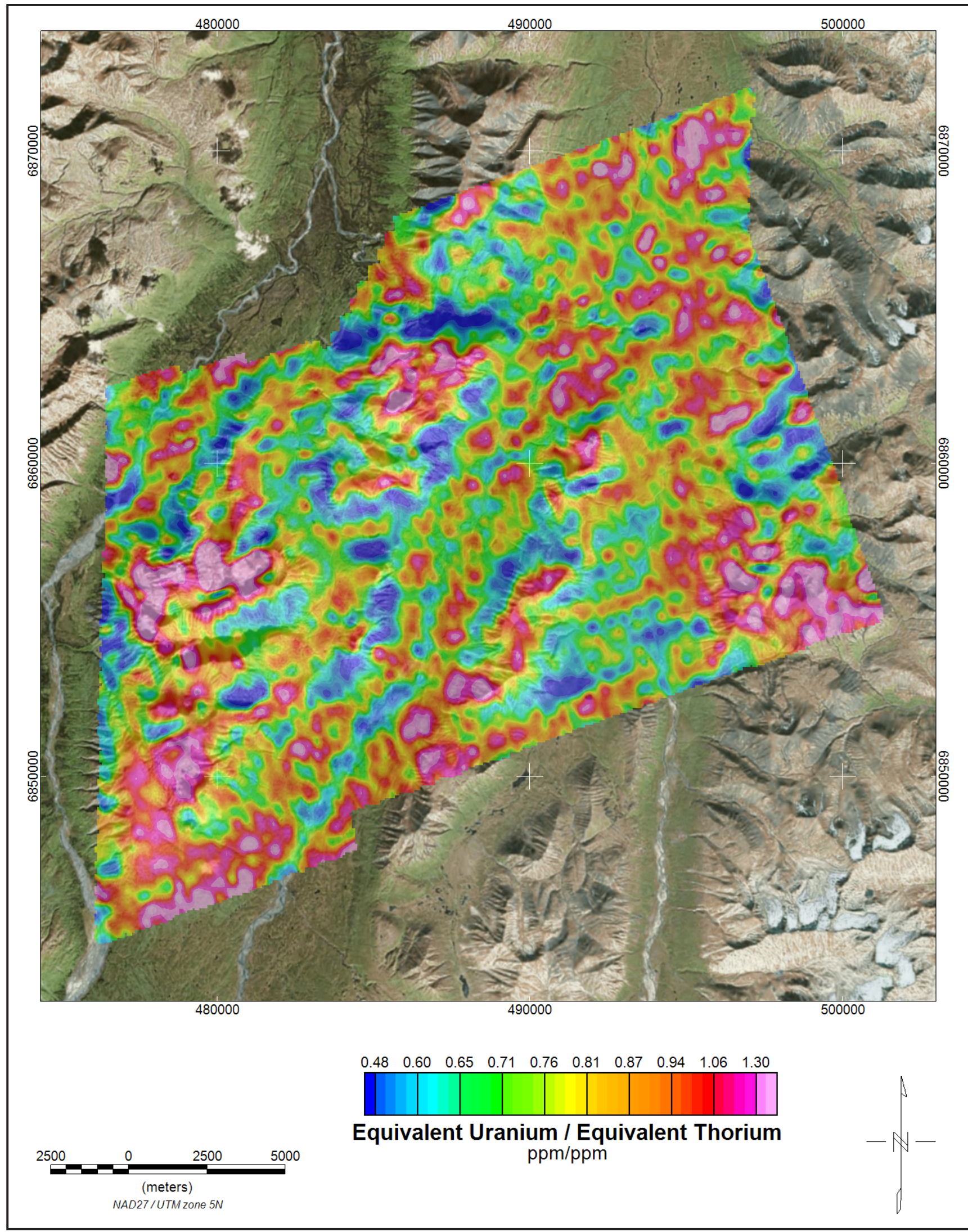

Figure 16. The gamma-ray spectrometry data were recorded at a 1.0 second sample rate into a 256 channel main and radon spectra using a Radiation Solutions RS-500 gamma-ray spectrometer. After removal of the background, the data were corrected for spectral interferences, changes in temperature, pressure, and departures from the planned survey elevation of $60 \mathrm{~m}$. The data were then converted to standard concentration units which were interpolated to a $100 \mathrm{~m}$ grid using a minimum curvature technique. 


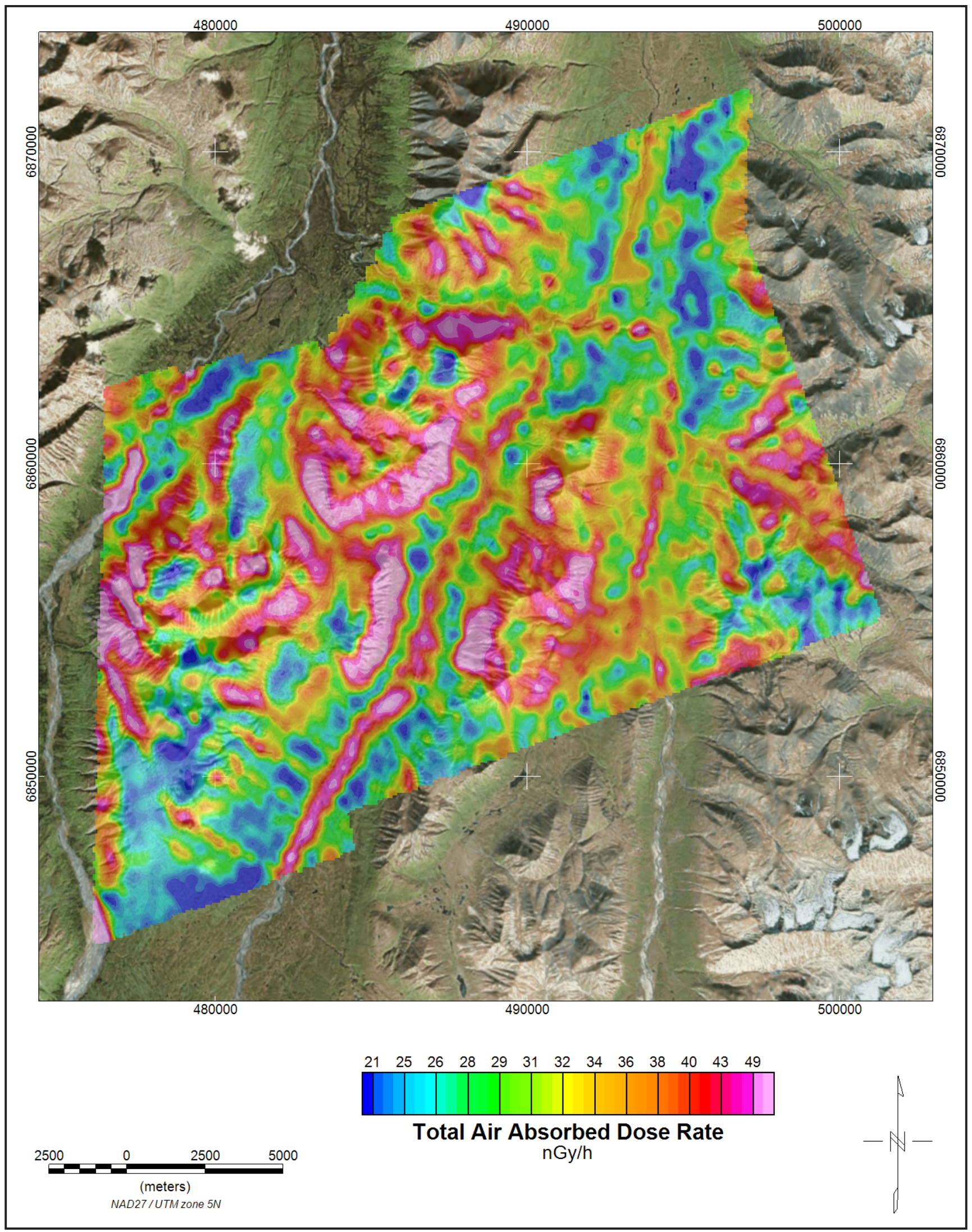

Figure 17. The gamma-ray spectrometry data were recorded at a 1.0 second sample rate into a 256 channel main and radon spectra using a Radiation Solutions RS-500 gamma-ray spectrometer. After removal of the background, the data were corrected for spectral interferences, changes in temperature, pressure, and departures from the planned survey elevation of $60 \mathrm{~m}$. The data were then converted to standard concentration units which were interpolated to a $100 \mathrm{~m}$ grid using a minimum curvature technique. 
Table 1. Copies of the following maps are included at the end of this booklet. The low-resolution, page-size maps included in this booklet are intended to be used as a search tool and are not the final product. Large-scale, full-resolution versions of each map are available to download on this publication's citation page: http://doi.org/10.14509/30188.

\begin{tabular}{|c|c|}
\hline Map Title & Description \\
\hline middlestyx_residualmag_topo_map.pdf & residual magnetic field grid with topographic base map \\
\hline middlestyx_residualmag_contours_plss_map.pdf & residual magnetic field grid with contours and public land survey system base layer \\
\hline middlestyx_calculated1vd_topo_map.pdf & calculated first vertical derivative grid with topographic base map \\
\hline middlestyx_analyticsignal_topo_map.pdf & analytic signal grid with topographic base map \\
\hline middlestyx_analyticsignal_contours_plss_map.pdf & analytic signal grid with contours and public land survey system base layer \\
\hline middlestyx_tiltderivative_contours_topo_map.pdf & magnetic tilt derivative grid with contours and topographic base map \\
\hline middlestyx_residualmag_shaded_tiltderivative_contours_topo_map.pdf & color shaded residual magnetic field grid with magnetic tilt derivative contours and topographic base map \\
\hline middlestyx_res56khz_topo_map.pdf & $56,000 \mathrm{~Hz}$ apparent resistivity grid with topographic base map \\
\hline middlestyx_res56khz_contours_plss_map.pdf & $56,000 \mathrm{~Hz}$ apparent resistivity grid with contours and public land survey system base layer \\
\hline middlestyx_res7200hz_topo_map.pdf & $7,200 \mathrm{~Hz}$ apparent resistivity grid with topographic base map \\
\hline middlestyx_res7200hz_contours_plss_map.pdf & $7,200 \mathrm{~Hz}$ apparent resistivity grid with contours and public land survey system base layer \\
\hline middlestyx_res900hz_topo_map.pdf & $900 \mathrm{~Hz}$ apparent resistivity grid with topographic base map \\
\hline middlestyx_res900hz_contours_plss_map.pdf & $900 \mathrm{~Hz}$ apparent resistivity grid with contours and public land survey system base layer \\
\hline middlestyx_rad_ratio_th_k_topo_map.pdf & ratio of equivalent thorium to percent potassium grid with topographic base map \\
\hline middlestyx_rad_ratio_th_k_contours_plss_map.pdf & ratio of equivalent thorium to percent potassium grid with contours and public land survey system base layer \\
\hline middlestyx_rad_ratio_u_k_topo_map.pdf & ratio of equivalent uranium to percent potassium grid with topographic base map \\
\hline middlestyx_rad_ratio_u_k_contours_plss_map.pdf & ratio of equivalent uranium to percent potassium grid with contours and public land survey system base layer \\
\hline middlestyx_rad_ratio_u_th_topo_map.pdf & ratio of equivalent uranium to equivalent thorium grid with topographic base map \\
\hline middlestyx_rad_ratio_u_th_contours_plss_map.pdf & ratio of equivalent uranium to equivalent thorium grid with contours and public land survey system base layer \\
\hline middlestyx_rad_pct_k_topo_map.pdf & percent potassium grid with topographic base map \\
\hline middlestyx_rad_pct_k_contours_plss_map.pdf & percent potassium grid with contours and public land survey system base layer \\
\hline middlestyx_rad_equiv_th_topo_map.pdf & equivalent thorium with topographic base map \\
\hline middlestyx_rad_equiv_th_contours_plss_map.pdf & equivalent thorium with contours and public land survey system base layer \\
\hline middlestyx_rad_equiv_u_topo_map.pdf & equivalent uranium with topographic base map \\
\hline middlestyx_rad_equiv_u_contours_plss_map.pdf & equivalent uranium with contours and public land survey system base layer \\
\hline middlestyx_rad_naadr_topo_map.pdf & natural air absorbed dose rate with topographic base map \\
\hline middlestyx_rad_naadr_contours_plss_map.pdf & natural air absorbed dose rate with contours and public land survey system base layer \\
\hline middlestyx_rad_ternary_topo_map.pdf & radiometric ternary grid with topographic base map \\
\hline middlestyx_interpretation_plss_map.pdf & interpretation map with public land survey system base layer \\
\hline middlestyx_interpretation_residualmag_plss_map.pdf & interpretation map with residual magnetic field grid and public land survey system base layer \\
\hline middlestyx_emanomalies_residualmag_detailed_topo_map_1of2.pdf & detailed electromagnetic anomalies with residual magnetic field grid and topographic base map \\
\hline middlestyx_emanomalies_residualmag_detailed_topo_map_2of2.pdf & detailed electromagnetic anomalies with residual magnetic field grid and topographic base map \\
\hline
\end{tabular}




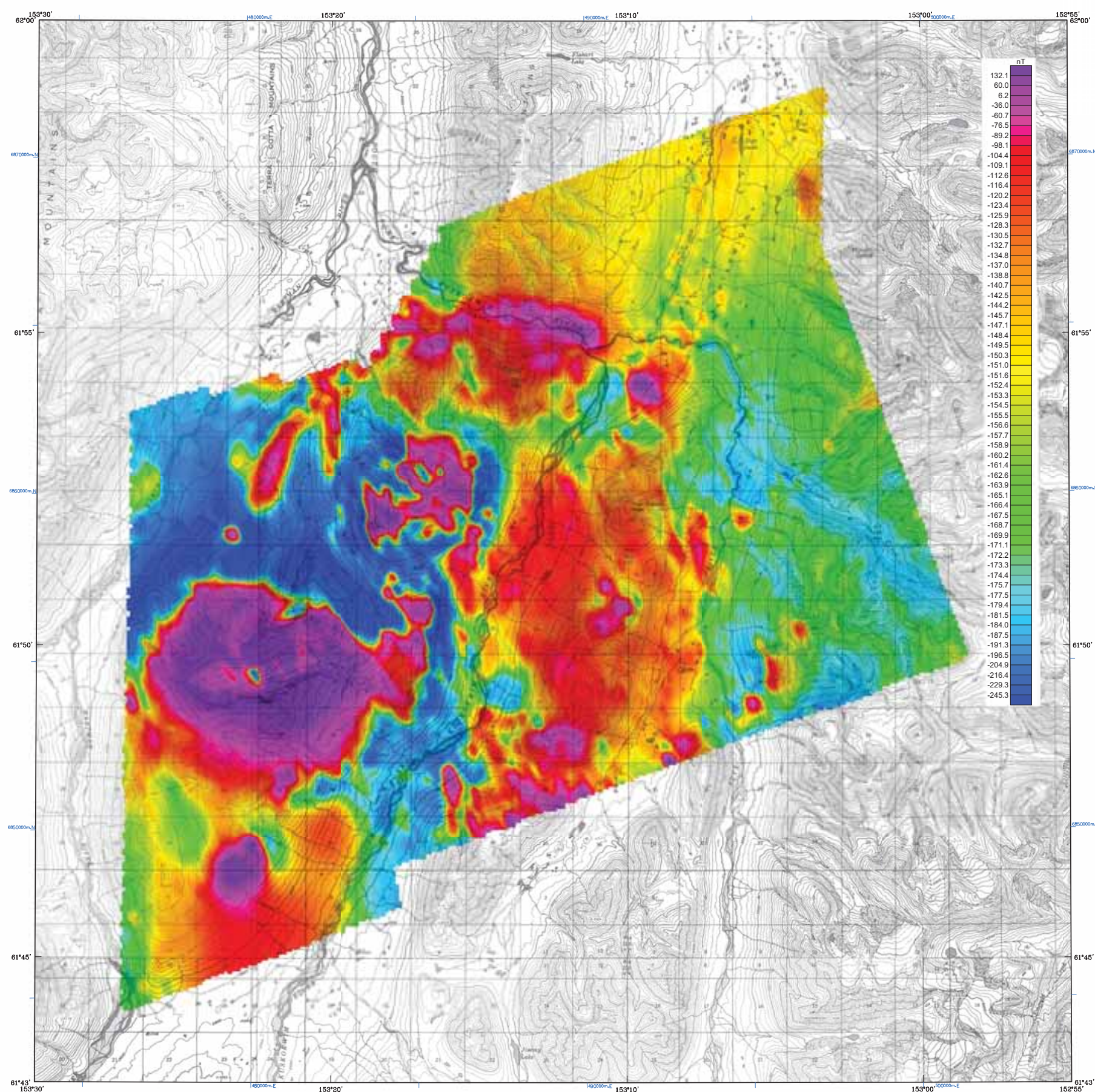

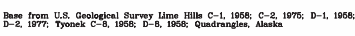

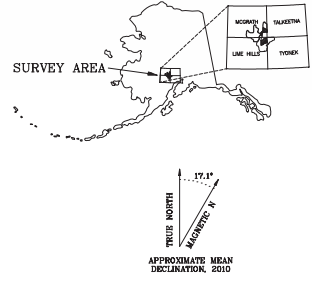

DESCRIPTIVE NOTES

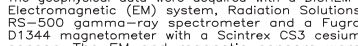

sensor. The EM and magnetic sensors wer
flown at a height of 100 feet. The garmma-ray

and laser altimeters,
$50,60 \mathrm{~Hz}$ monitors and video camera. Fligh
were performed with an AS-350-B3. Squirt

lines with a spacing gavorter of a flimile

lines at whervals of aprode
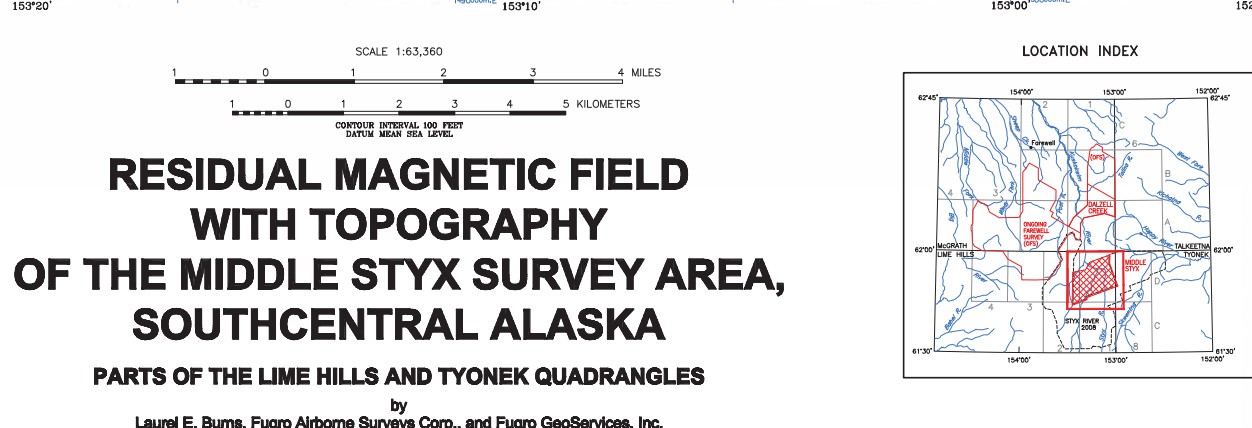

by
Laurel E. Bums, Fugro Arbome Surveys Corp., and Fugro GeoServices, Inc.
2013

SURVEY HISTORY

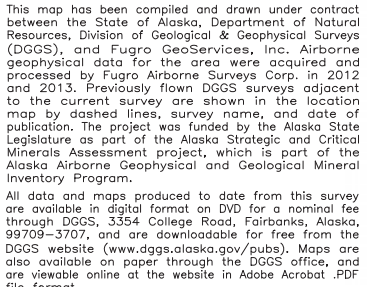




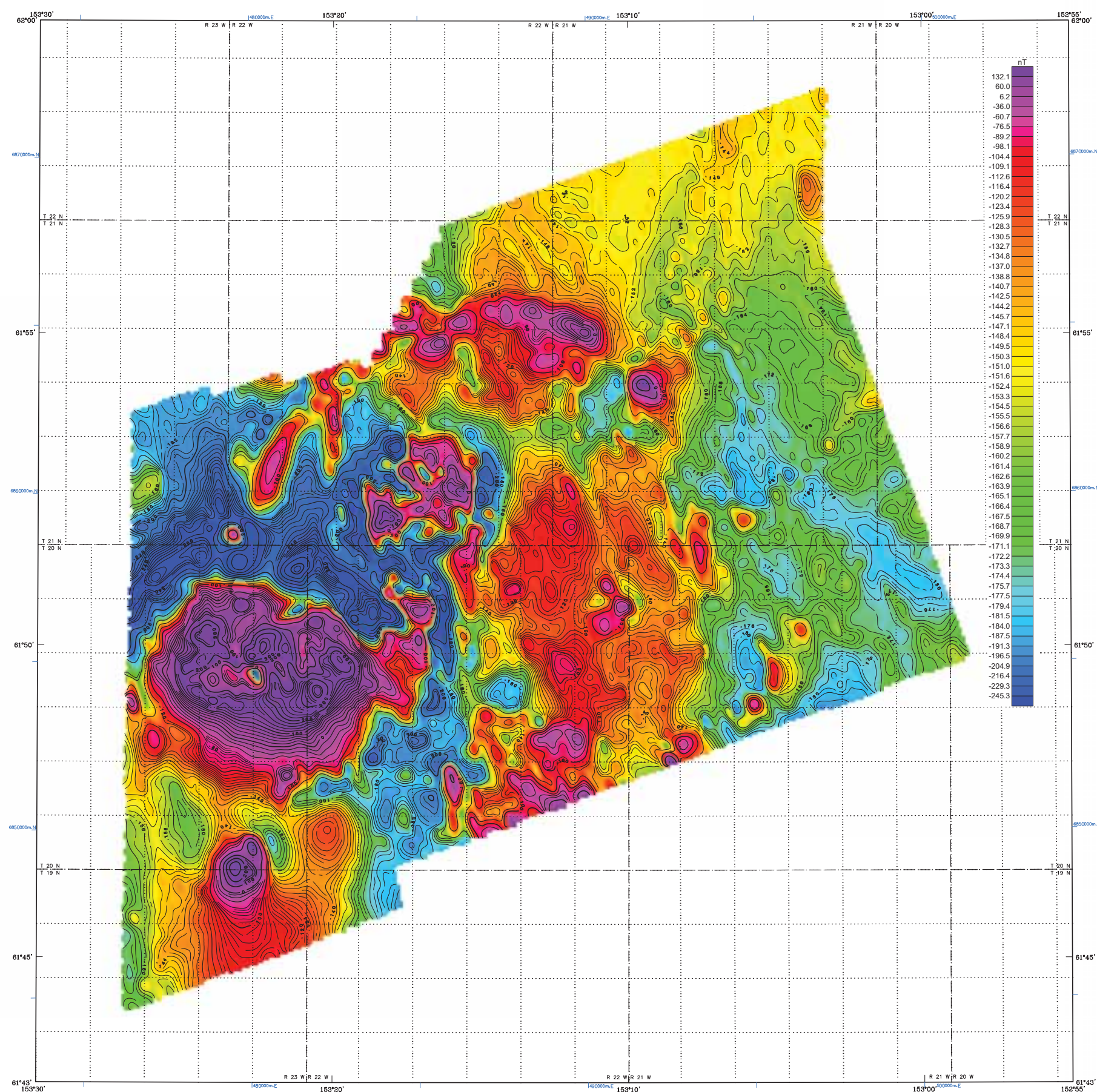

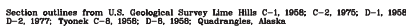
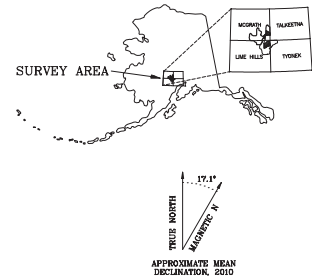

DESCRIPTIVE NOTES

The geophysical data, were acquired with a DIGHEM
Electromagnetic (EM) system, Radiation Solutions
RS-500 gamma-ray spectrometer and a Fugro

.
neight of 200 feet

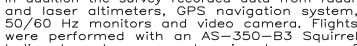

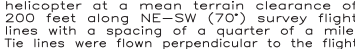

the lines were flown perpendicular to the fligh

A Novatel OEM4-G2L Global Positioning System
was used for navigation. The helicopter position
was derived every 0.5 seconds using post-flight

differential positioning to a relative accuracy
better th

preroid, 1927 North American datum using
central meridian (CM) of $153^{\circ}$, a north constan
ontral

of $\mathrm{O}$ and an east constant of ' 500,000 . Positional
accuracy of the presented data is better than
$10 \mathrm{~m} w$

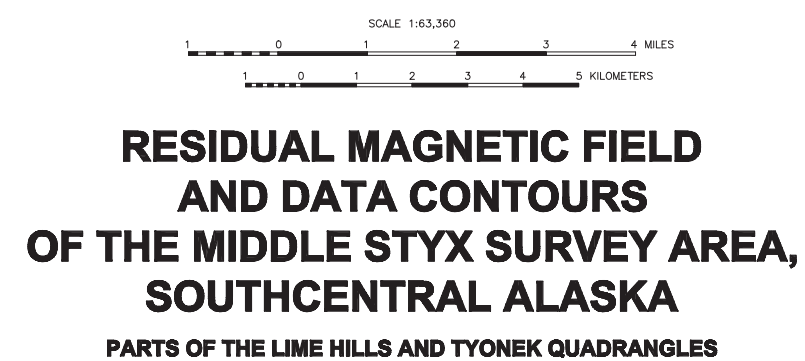

PARTS OF THE UME HILLS AND TYONEK QUADRANGLES

Laurel E. Bums, Fugro Airborne Surveys Corp., and Fugro GeoSenvices, Inc.
2013

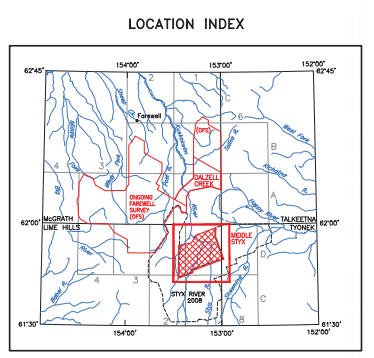

SURVEY HISTORY

RESIDUAL MAGNETIC FIELD

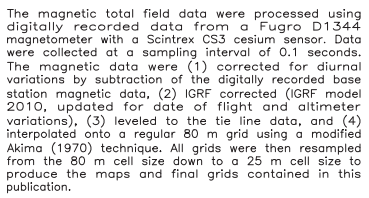

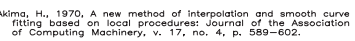

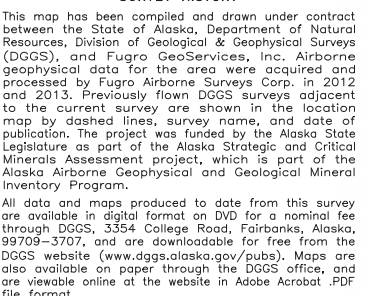




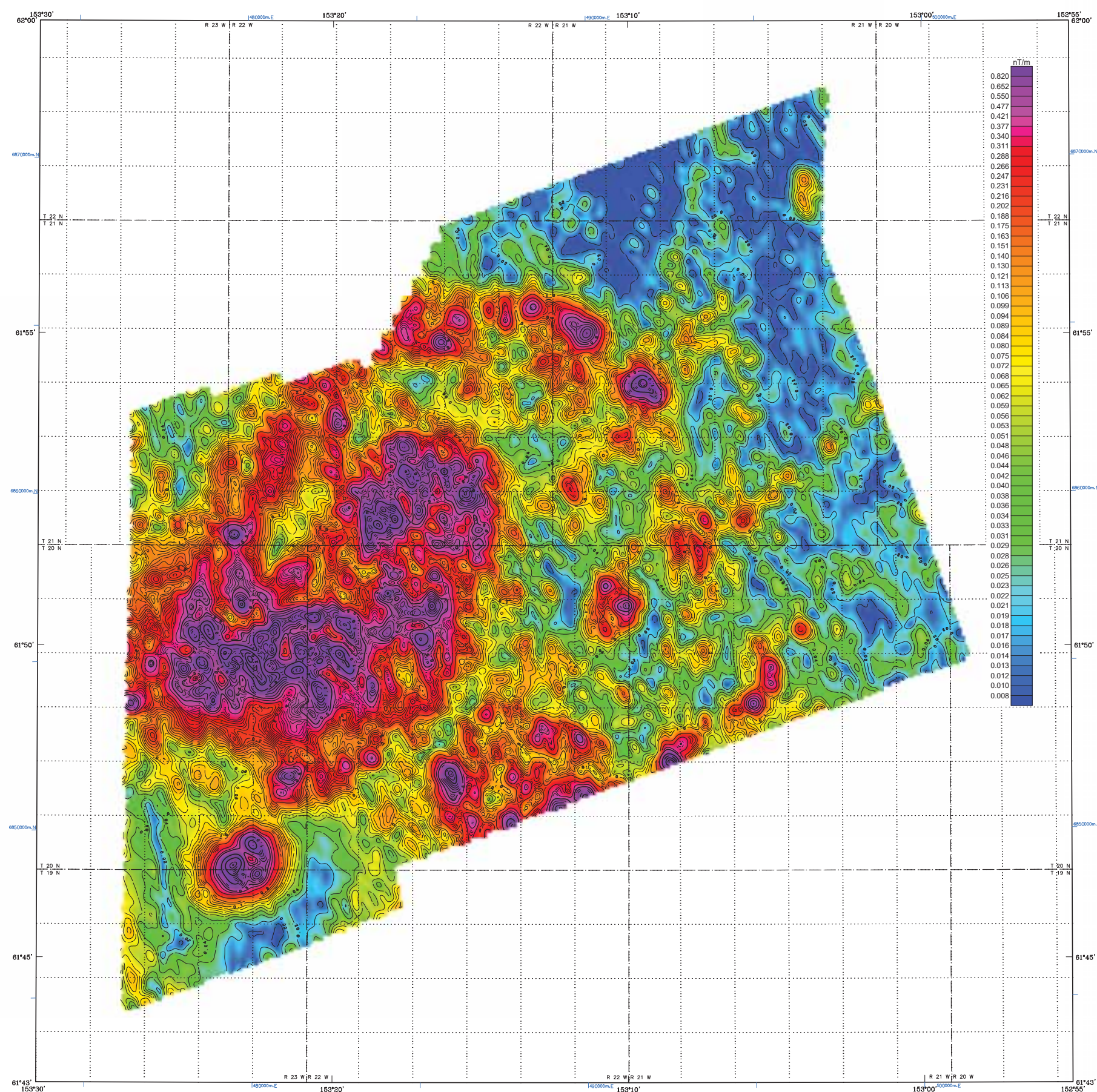

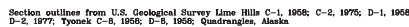
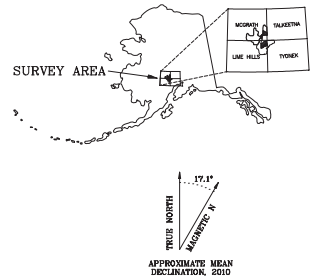

DESCRIPTIVE NOTES

The geophysical data, were acquired with a DIGHEM
Electromagnetic (EM) system, Radiation Solutions
RS-500 gamma-ray spectrometer and a Fugro

sensor. The EM and magnetic sensors were

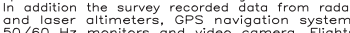

were performed with an AS-350- 33 . Squirre
helicopter at a mean terrain clearance o

lines with a spacing of a quarter of a mile
Tie lines were flown perpendicular to the flight

A Novatel OEM4-G2L Global Positioning System
was used for navigation. The helicopter position
was derived every 0.5 seconds using post-flight

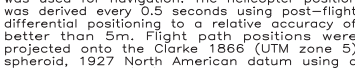

spheroid, 1927 North American datum using
central meridian (MM) of 153 , a notht constan

gccuracy of the presented data is better tha
$10 \mathrm{~m}$ with respect to the UTM grid

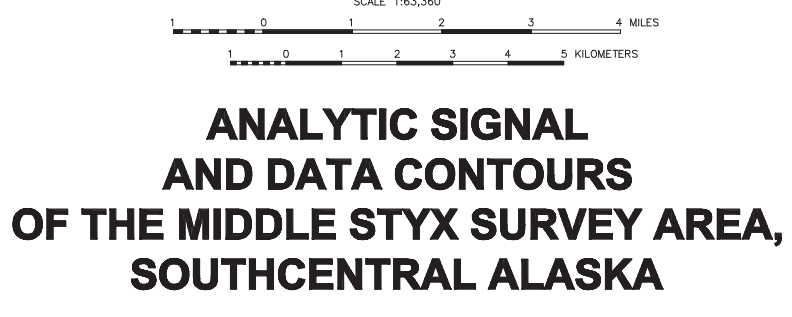

PARTS OF THE LME HILLS AND TYONEK QUADRANGLES

Laurel E. Bums, Fugro Airborne Surveys Corp., and Fugro GeoSenvices, Inc.
2013

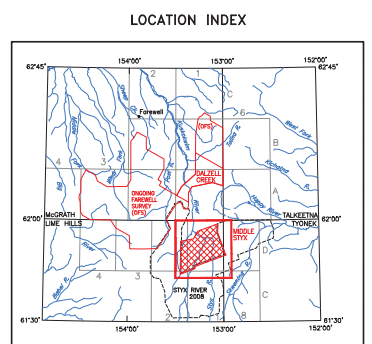

SURVEY HISTORY

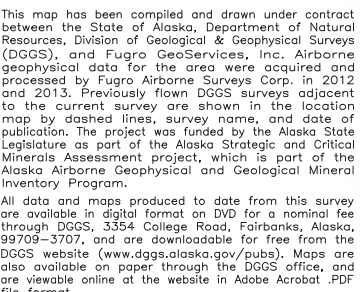




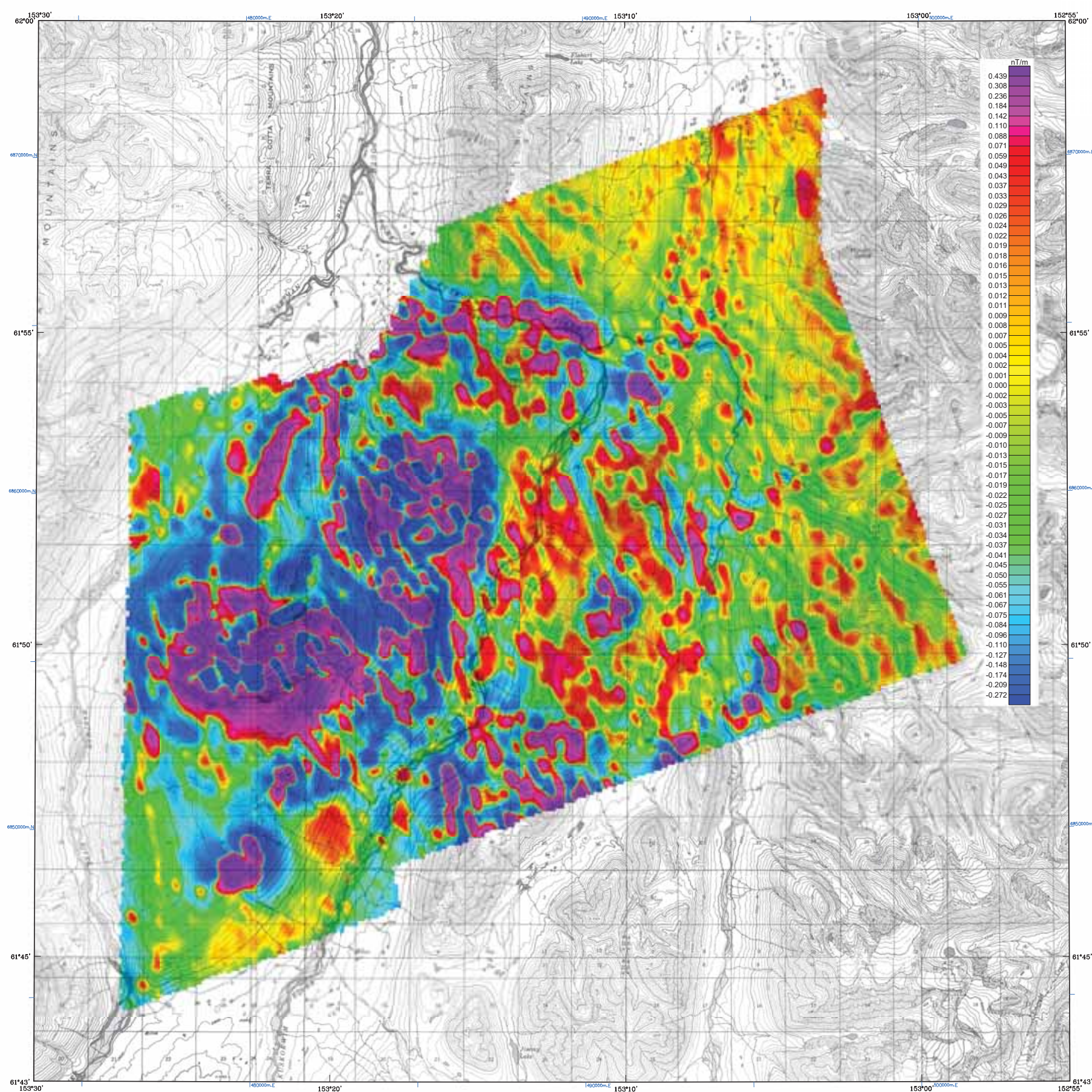

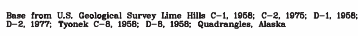

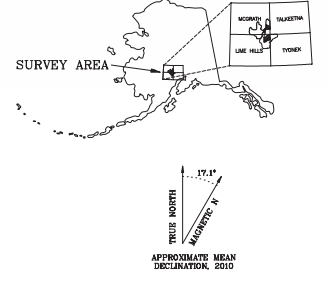

FIRST VERTICAL DERIVATIVE OF THE MAGNETIC FIELD OF THE MIDDLE STYX SURVEY AREA, SOUTHCENTRAL ALASKA

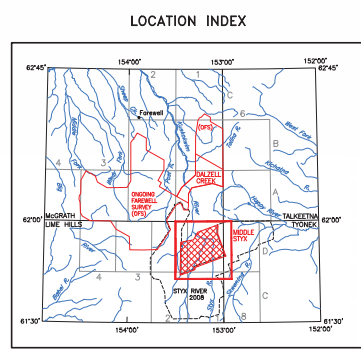

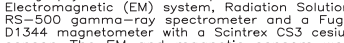

Laurel E. Bums, Fugro Arborne Surveys Corp., and Fugro GeoServices, Inc.
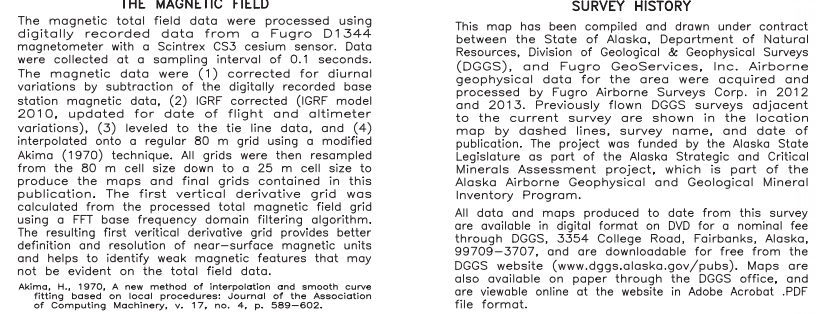


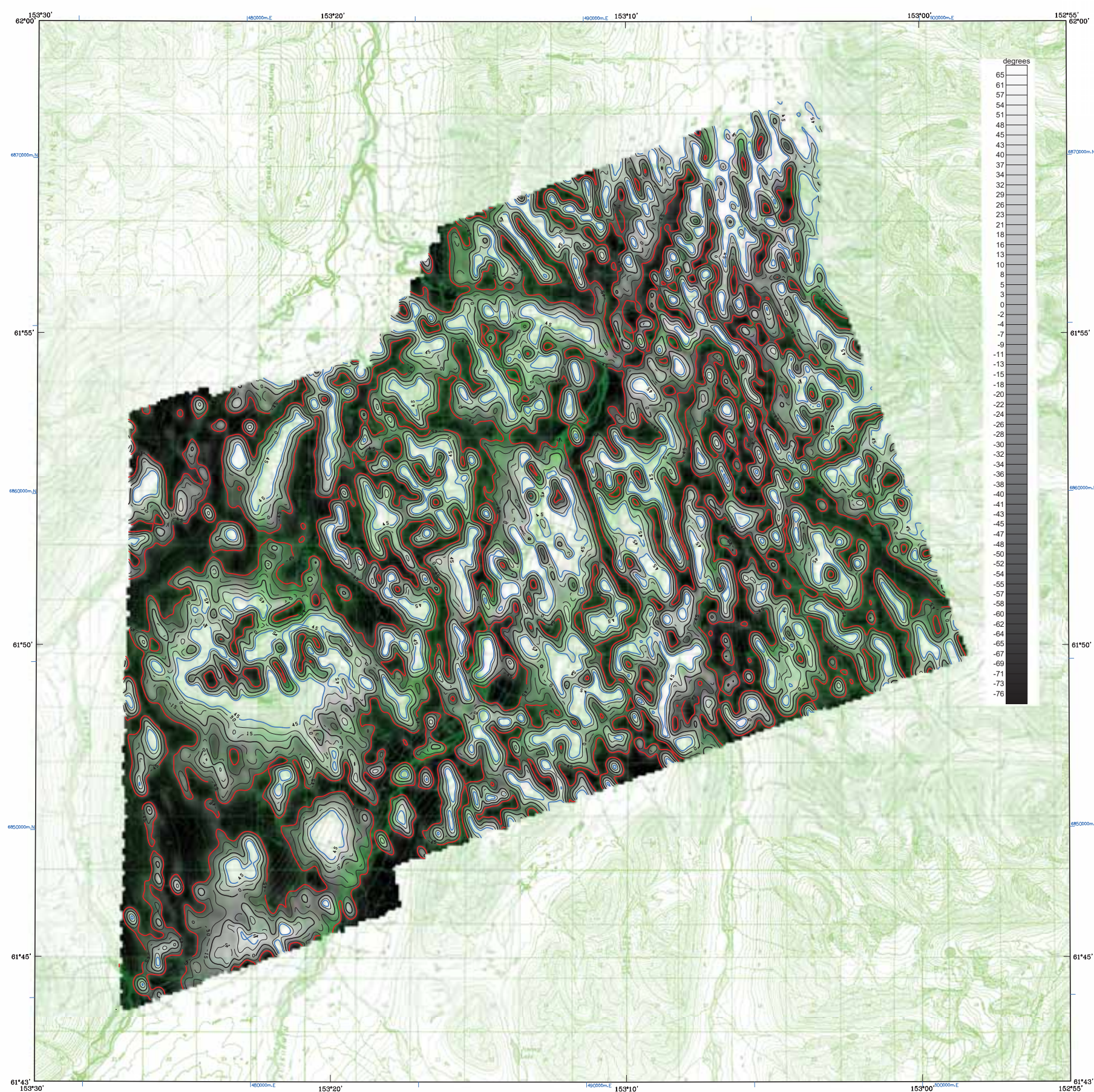

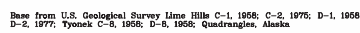

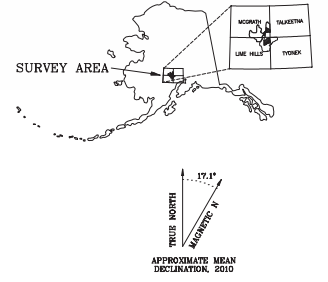

DESCRIPTIVE NOTES

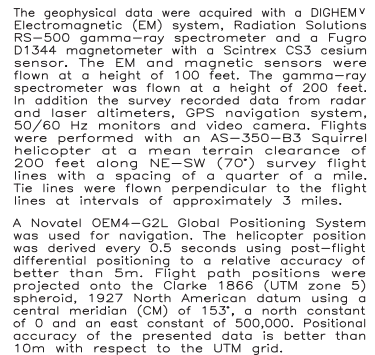

\section{MAGNETIC TILT DERIVATIVE WITH TOPOGRAPHY AND DATA CONTOURS OF THE MIDDLE STYX RIVER SURVEY AREA, SOUTHCENTRAL ALASKA \\ PARTS OF THE UME HILLS AND TYONEK QUADRANGLES}

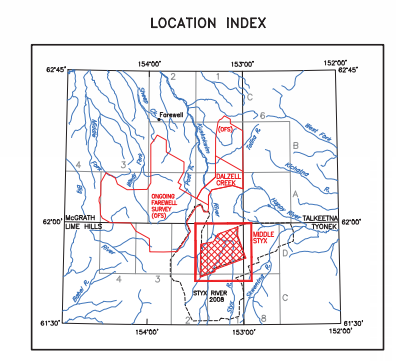

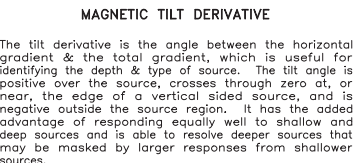
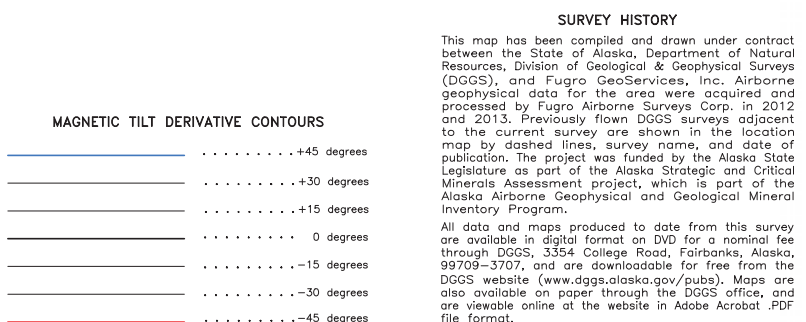


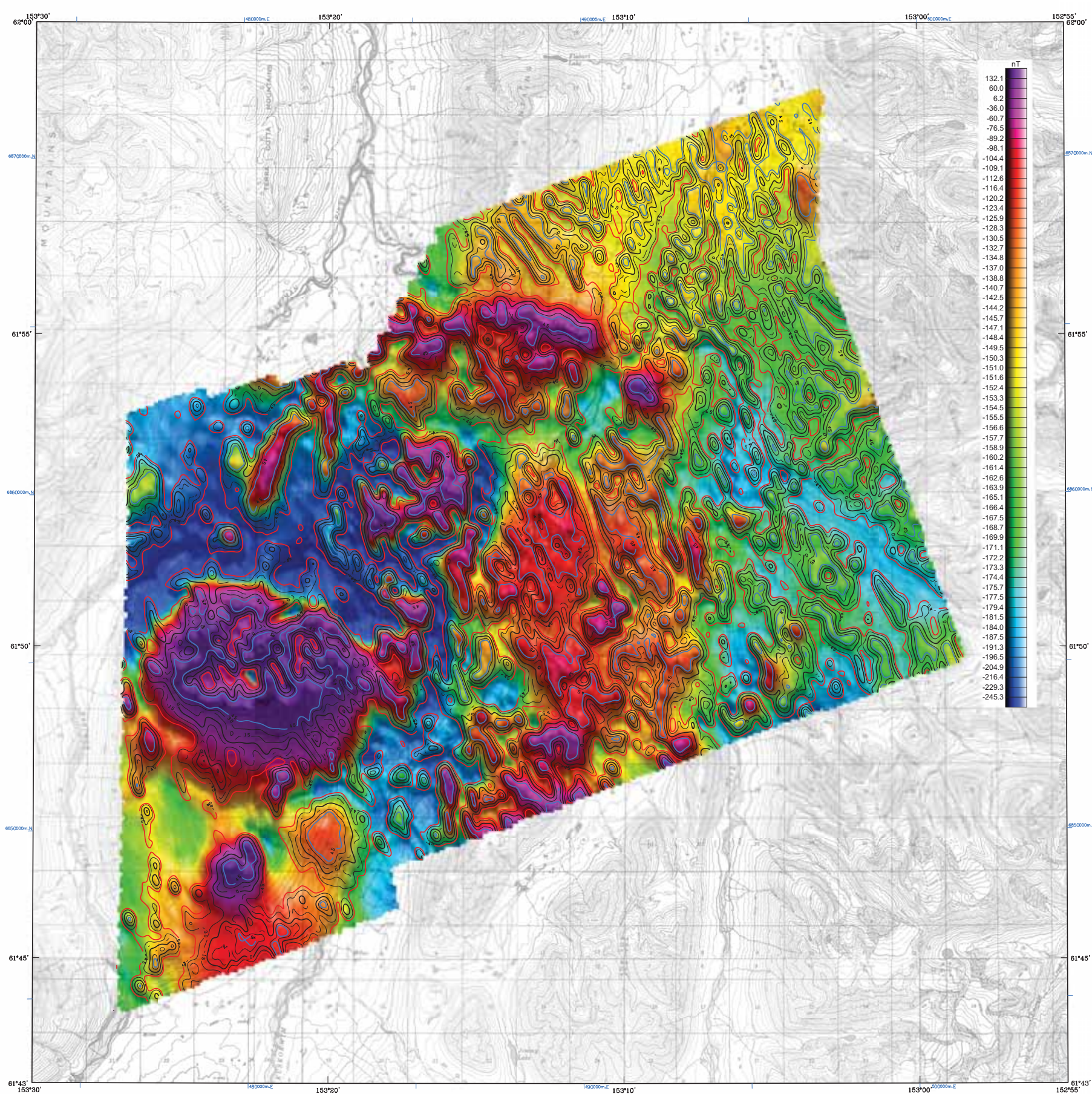

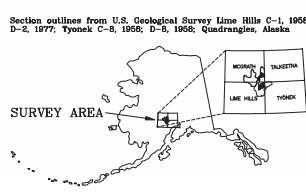

MAGNETIC TILT DERIVATIVE

The tilt derivative is the angle between the horizontal
gradient \& the total gradient, which is useful tor
identifying the depth \& 8 type of source. The tilt angle is

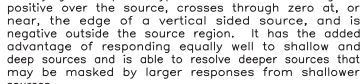

DESCRIPTIVE NOTES

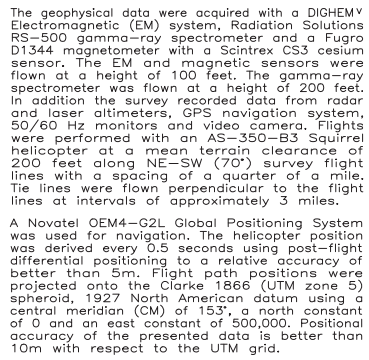

COLOR SHADOW RESIDUAL MAGNETIC FIELD WITH MAGNETIC TILT DERIVATIVE DATA CONTOURS OF THE MIDDLE STYX SURVEY AREA, SOUTHCENTRAL ALASKA

PARTS OF THE UME HILLS AND TYONEK QUADRANGLES

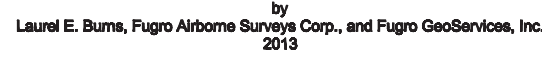

Sun Azimuth: 0 degrees; Sun Inclination: $\mathbf{4 5}$ degrees RESIDUAL MAGNETIC FIEL
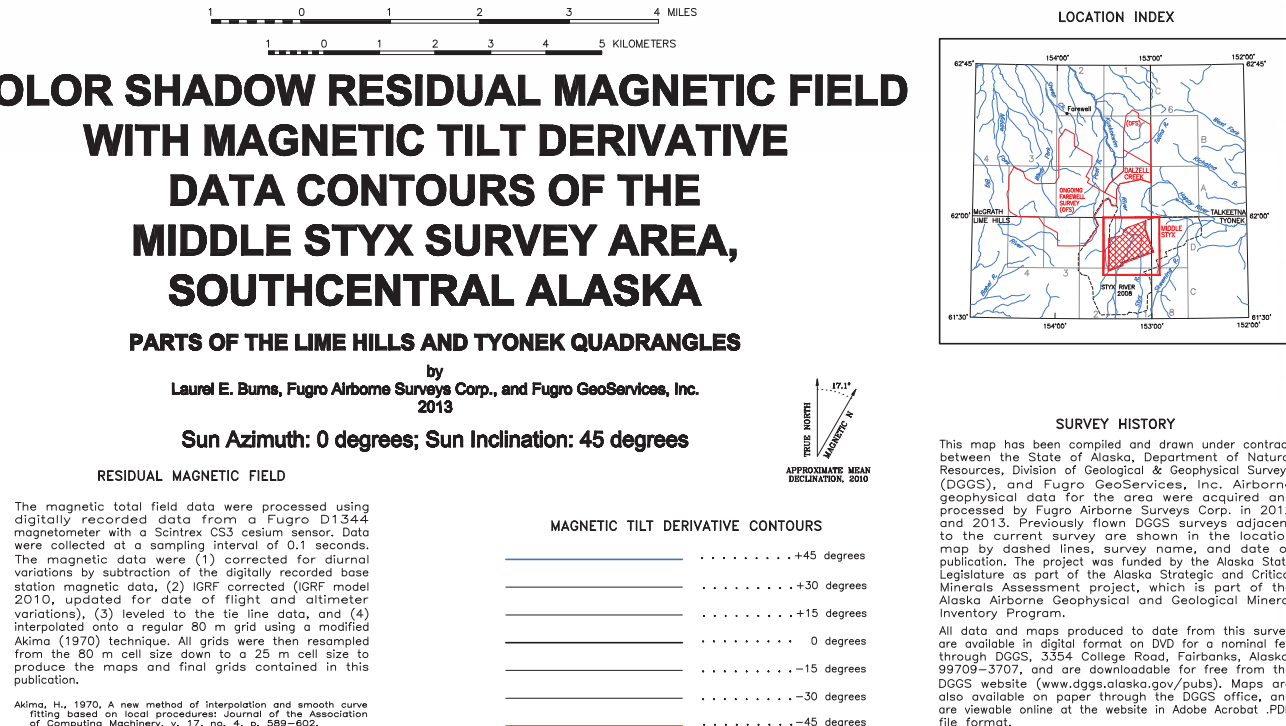

MAGNETIC TLLT DERIVATIVE CONTOURS
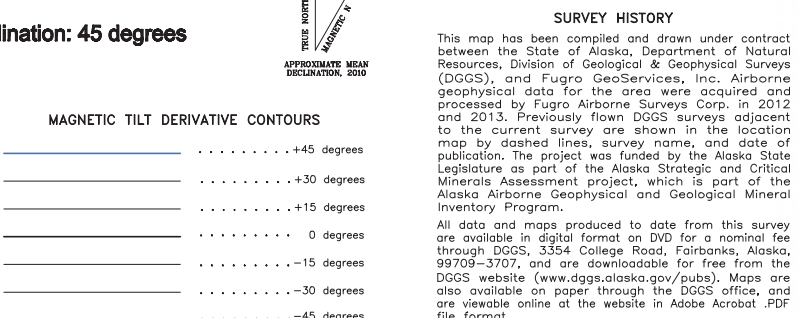


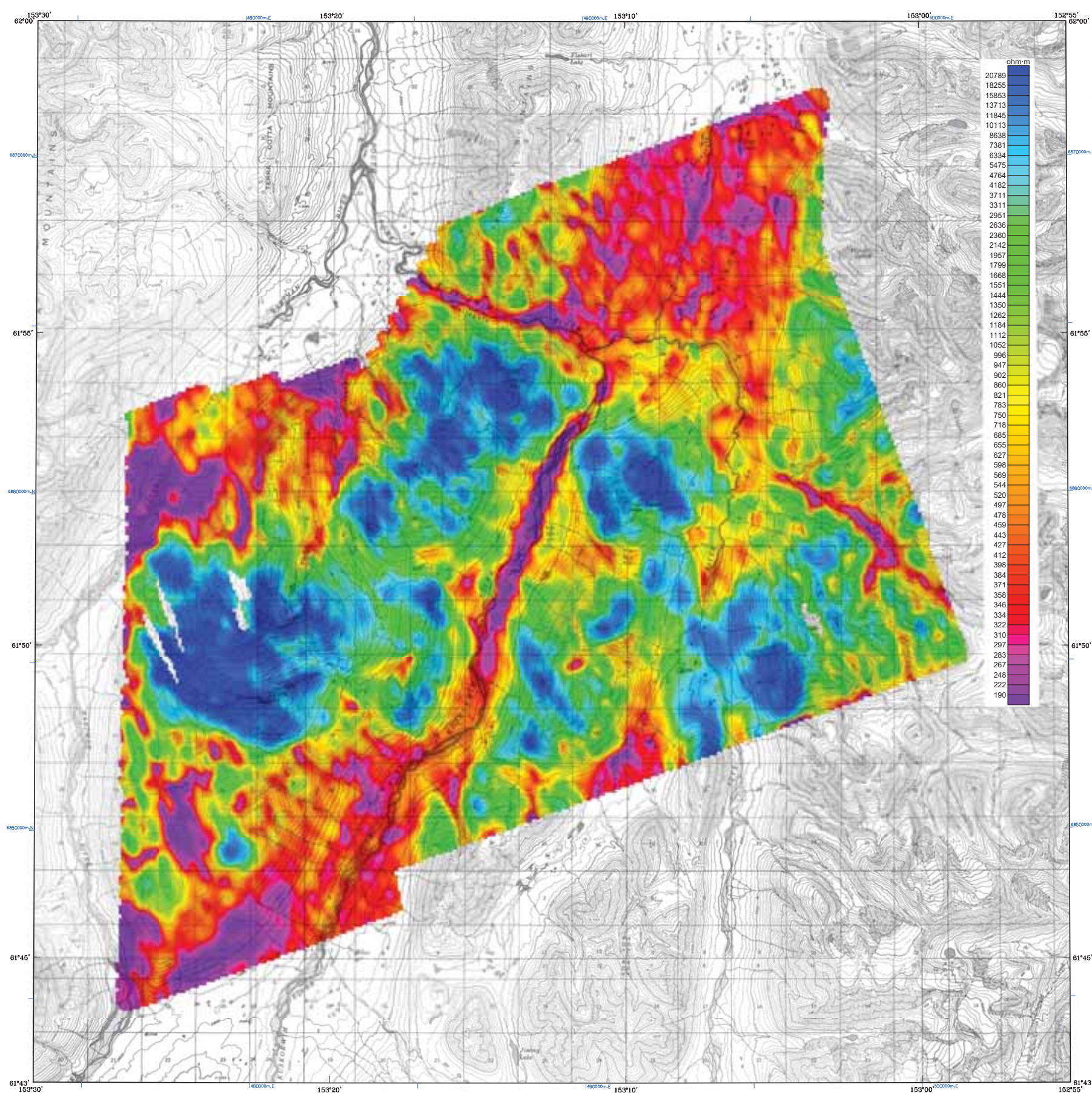

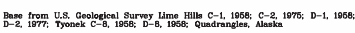

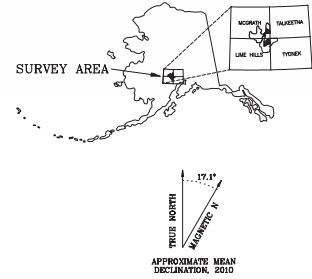

DESCRIPTIVE NOTES

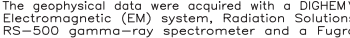

56,000 Hz COPLANAR APPARENT RESISTIVITY WITH TOPOGRAPHY OF THE MIDDLE STYX SURVEY AREA, SOUTHCENTRAL ALASKA PARTS OF THE UME HILLS AND TYONEK QUADRANGLES

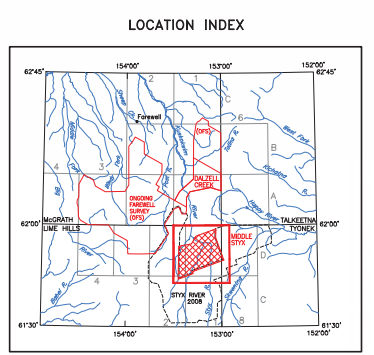

SURVEY HISTORY 


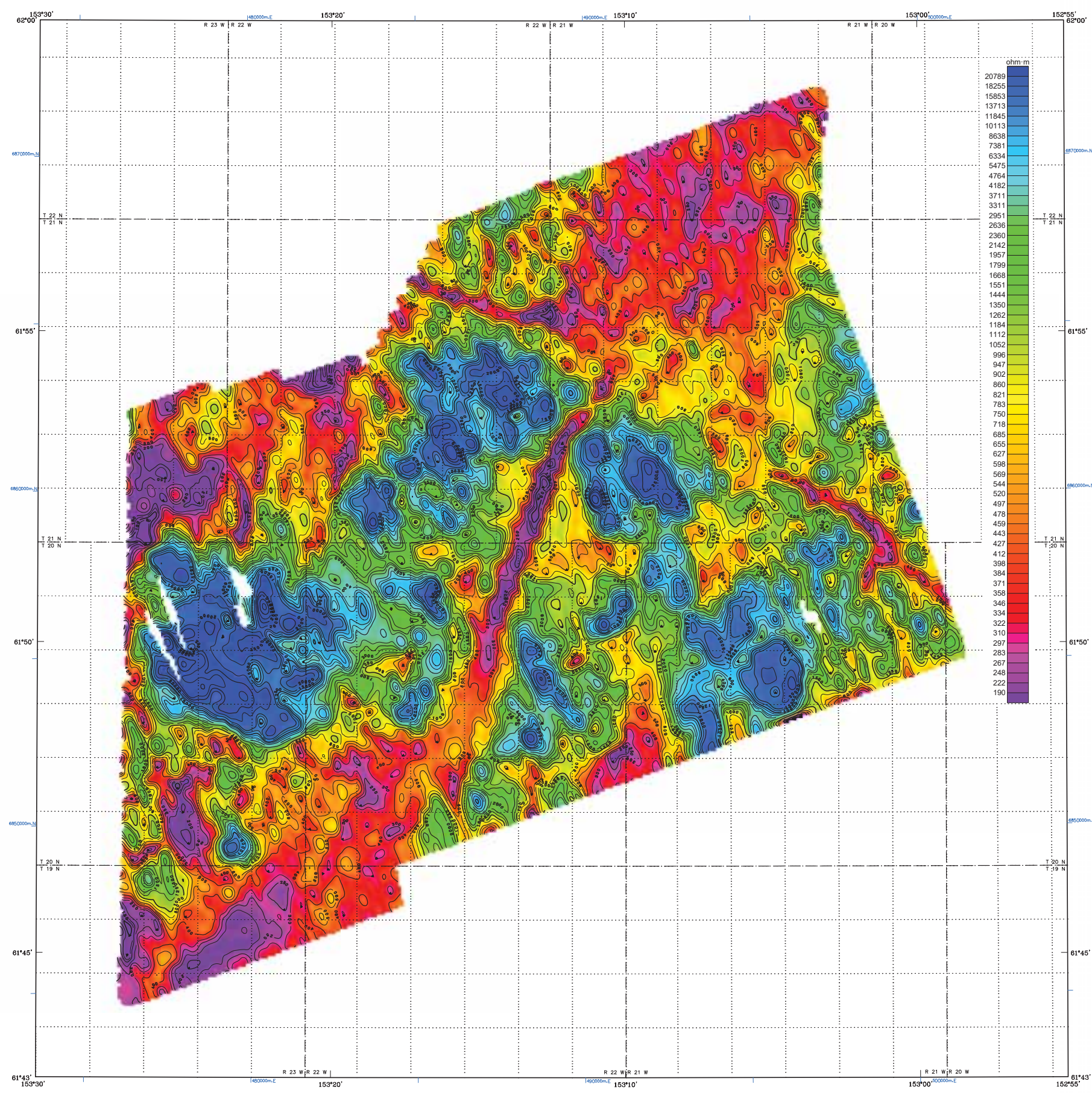

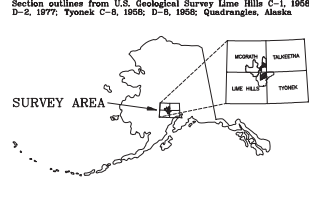

RESISTIVITY ALTITUDE LIMITS

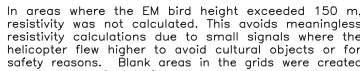

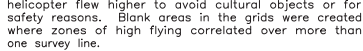

DESCRIPTIVE NOTES

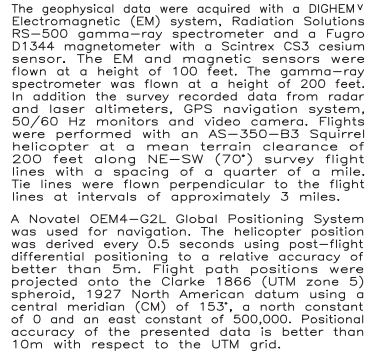

$56,000 \mathrm{~Hz}$ COPLANAR APPARENT RESISTIVITY AND DATA CONTOURS OF THE MIDDLE STYX SURVEY AREA, SOUTHCENTRAL ALASKA PARTS OF THE LIME HILLS AND TYONEK QUADRANGLES

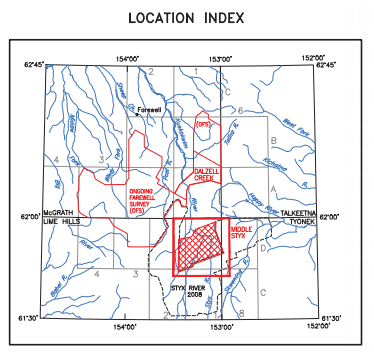

Laurel E. Bums, Fugro Airbome Surveys Corp., and Fugro GeoSenvices, Inc.
2013
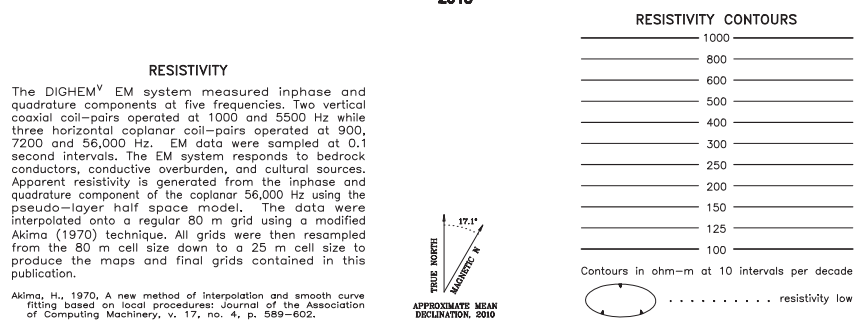

SURVEY HISTORY

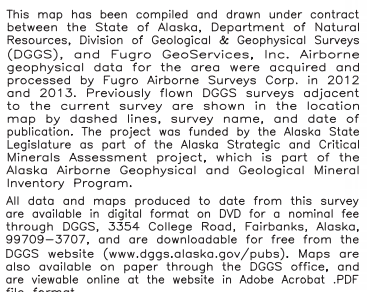




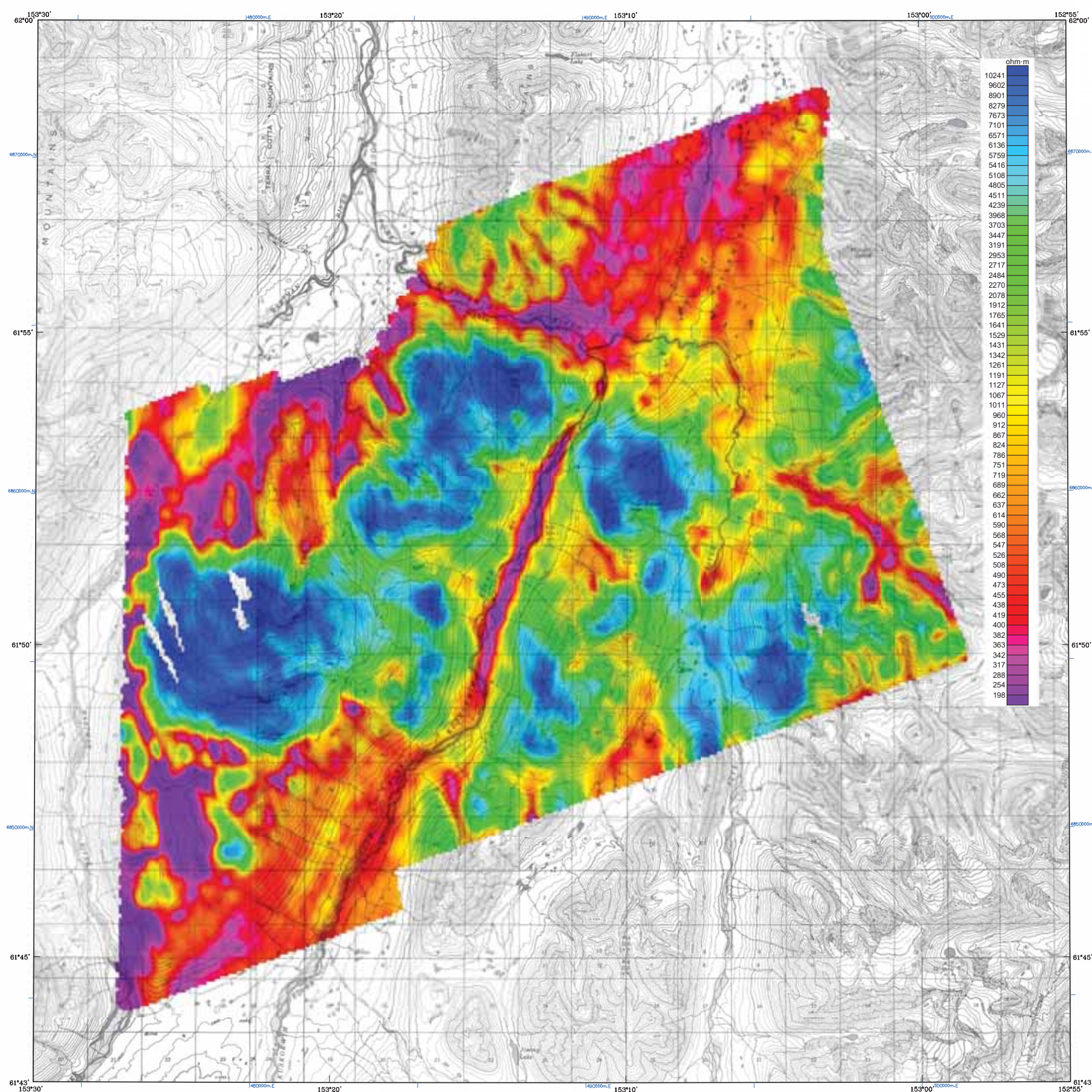

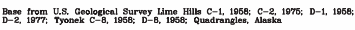

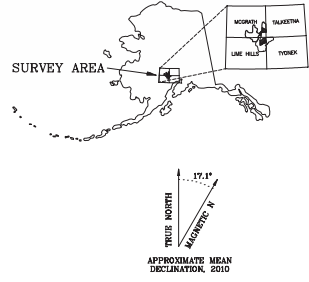

DESCRIPTIVE NOTES

\section{$7200 \mathrm{~Hz}$ COPLANAR APPARENT RESISTIVITY WITH TOPOGRAPHY OF THE MIDDLE STYX SURVEY AREA, SOUTHCENTRAL ALASKA PARTS OF THE LME HILLS AND TYONEK QUADRANGLES}

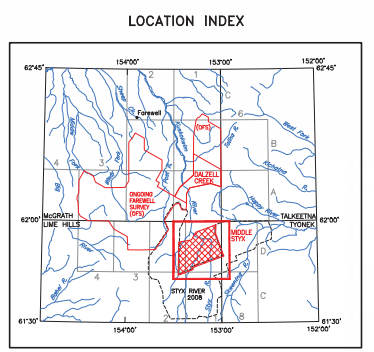

SURVEY HISTORY

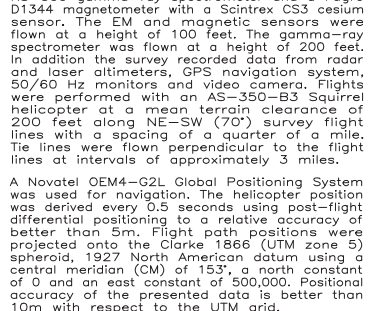




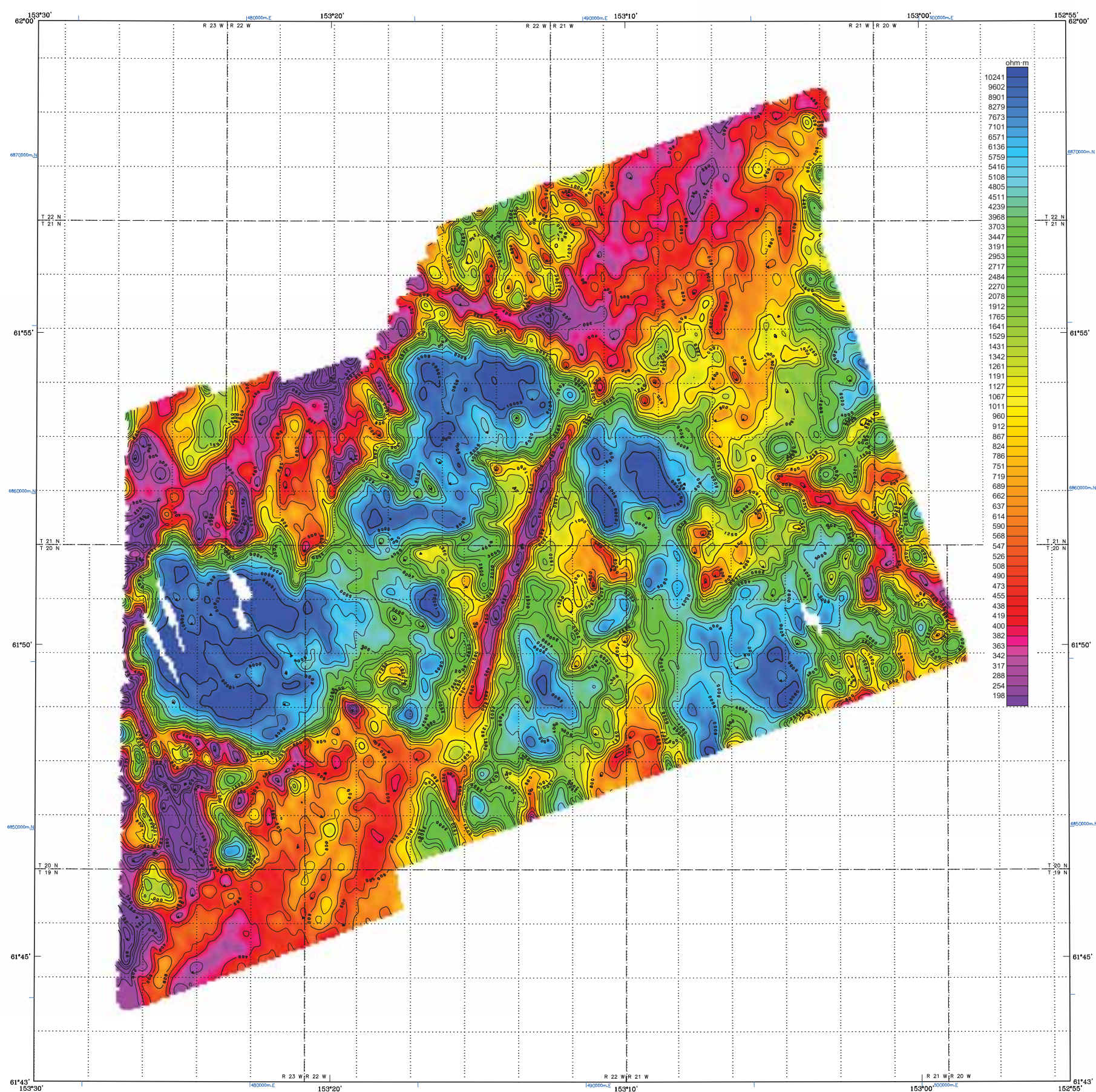

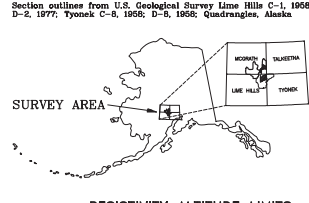

RESISTIVITY ALTITUDE LIMITS

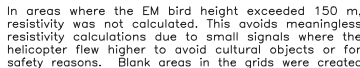
helicopter flew higher to avoid cultural objects or for
safety reasons. Blank areas in the grids were created
where zones of high flying correlated over more than
one survey line.

DESCRIPTIVE NOTES

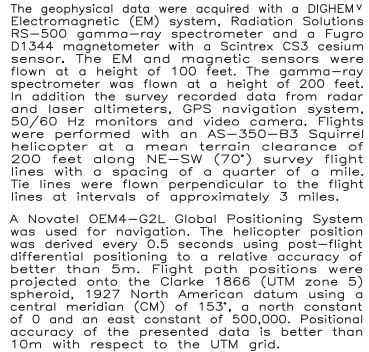

$7200 \mathrm{~Hz}$ COPLANAR APPARENT RESISTIVITY AND DATA CONTOURS OF THE MIDDLE STYX SURVEY AREA, SOUTHCENTRAL ALASKA PARTS OF THE LME HILLS AND TYONEK QUADRANGLES

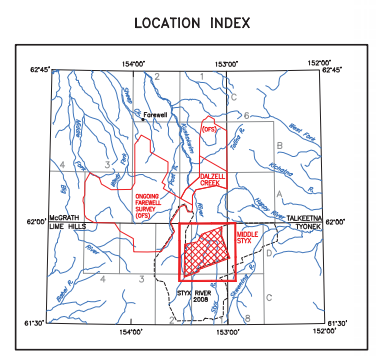

Laurel E. Bums, Fugro Airbome Surveys Corp., and Fugro GeoSenvices, Inc.
2013

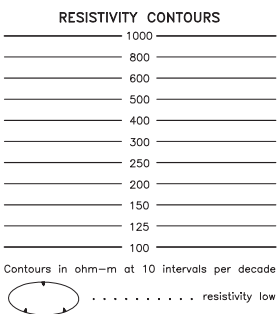

SURVEY HISTORY

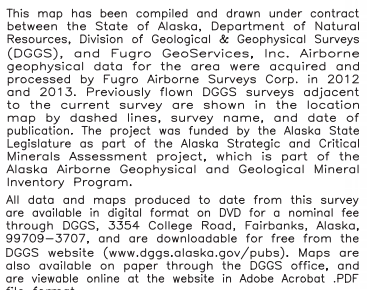




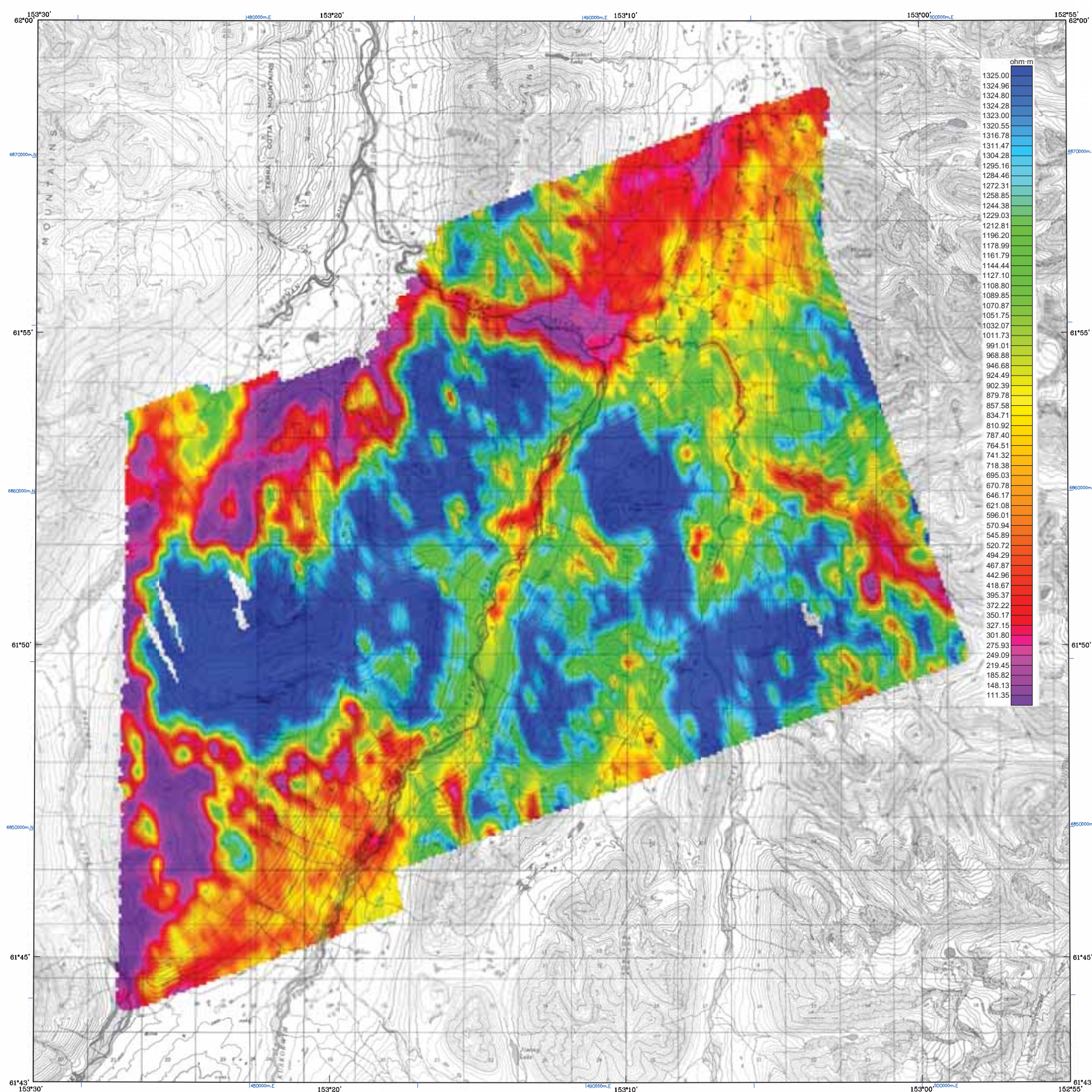

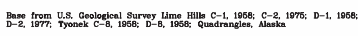

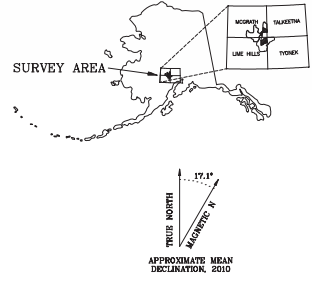

DESCRIPTIVE NOTES

Electromagnetic (EM) system, Raded with a DIGHEM Solution
RS-500

\section{$900 \mathrm{~Hz}$ COPLANAR APPARENT RESISTIVITY WITH TOPOGRAPHY OF THE MIDDLE STYX SURVEY AREA, SOUTHCENTRAL ALASKA PARTS OF THE UME HILLS AND TYONEK QUADRANGLES}

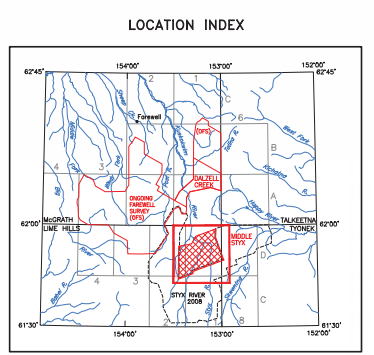

SURVEY HISTORY 


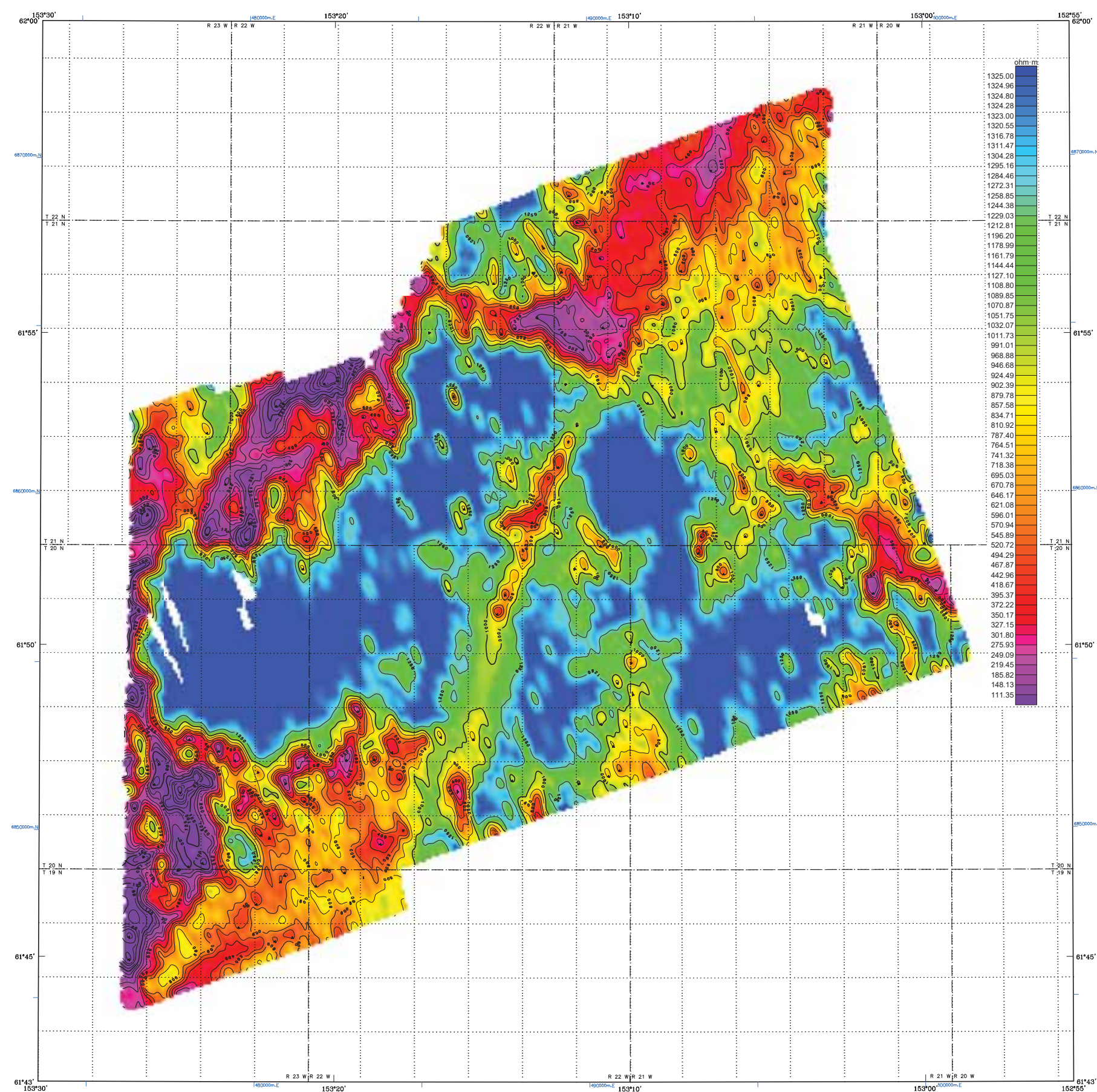

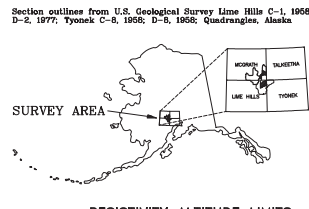

RESISTIVITY ALTITUDE LIMITS

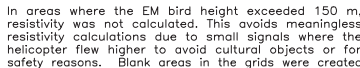
helicopter flew higher to avoid cultural objects or for
safety reasons. Blank areas in the grids were created
where zones of high flying correlated over more than
one survey line.

DESCRIPTIVE NOTES

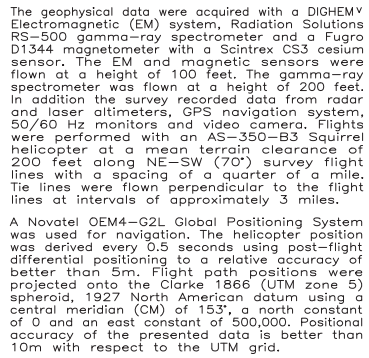

$900 \mathrm{~Hz}$ COPLANAR APPARENT RESISTIVITY AND DATA CONTOURS OF THE MIDDLE STYX SURVEY AREA, SOUTHCENTRAL ALASKA PARTS OF THE LME HILLS AND TYONEK QUADRANGLES

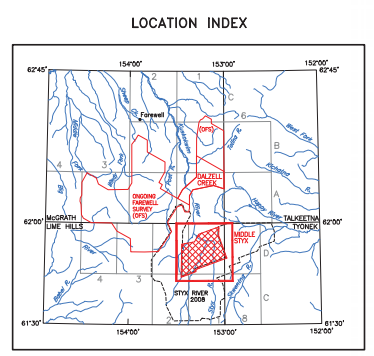

Laurel E. Bums, Fugro Airbome Surveys Corp., and Fugro GeoSenvices, Inc.
2013

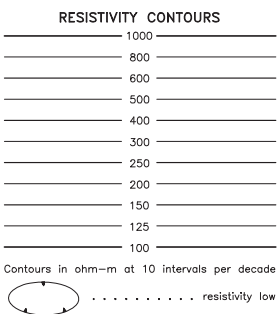

SURVEY HISTORY

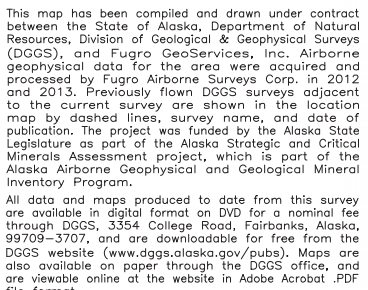




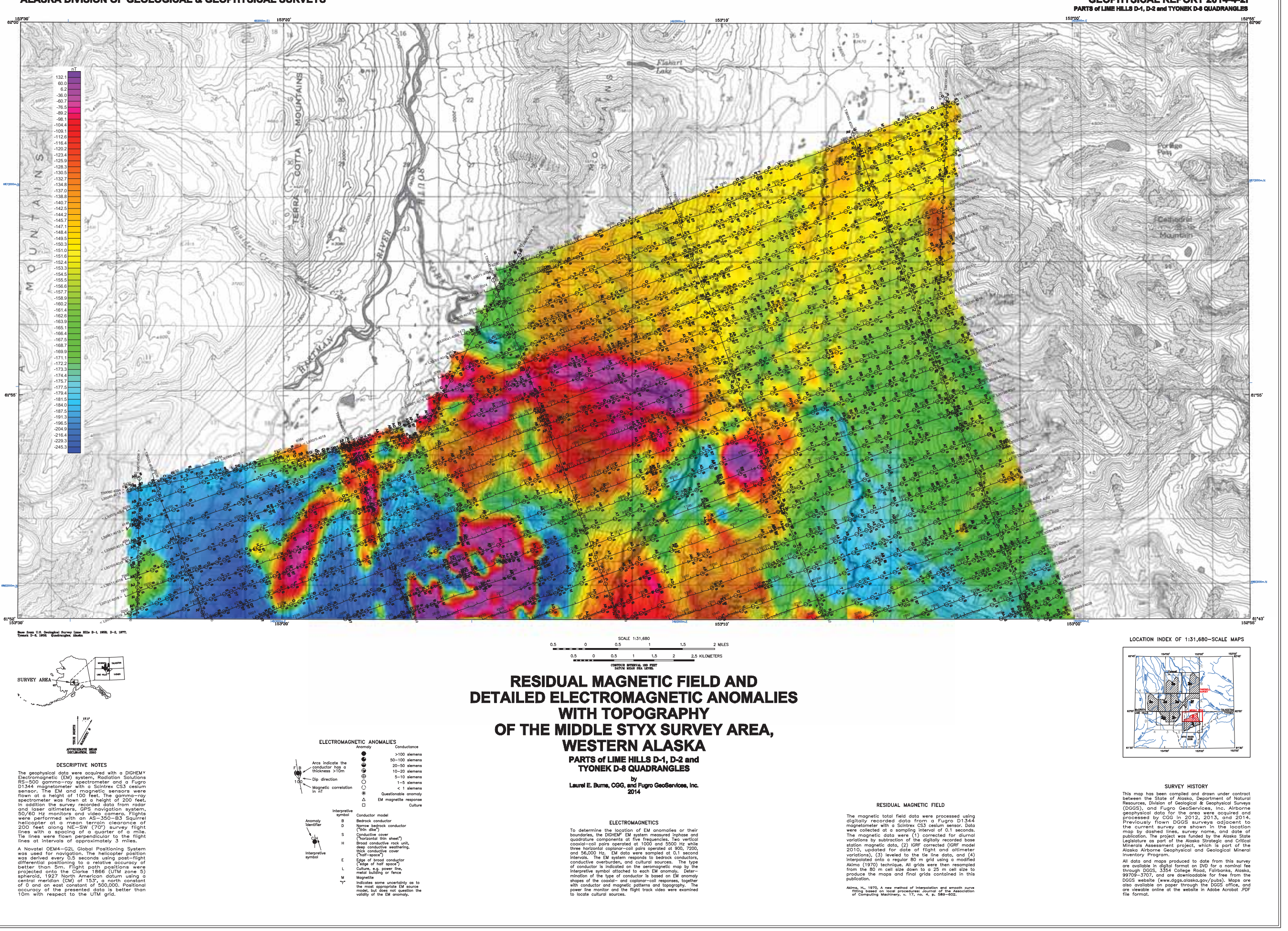




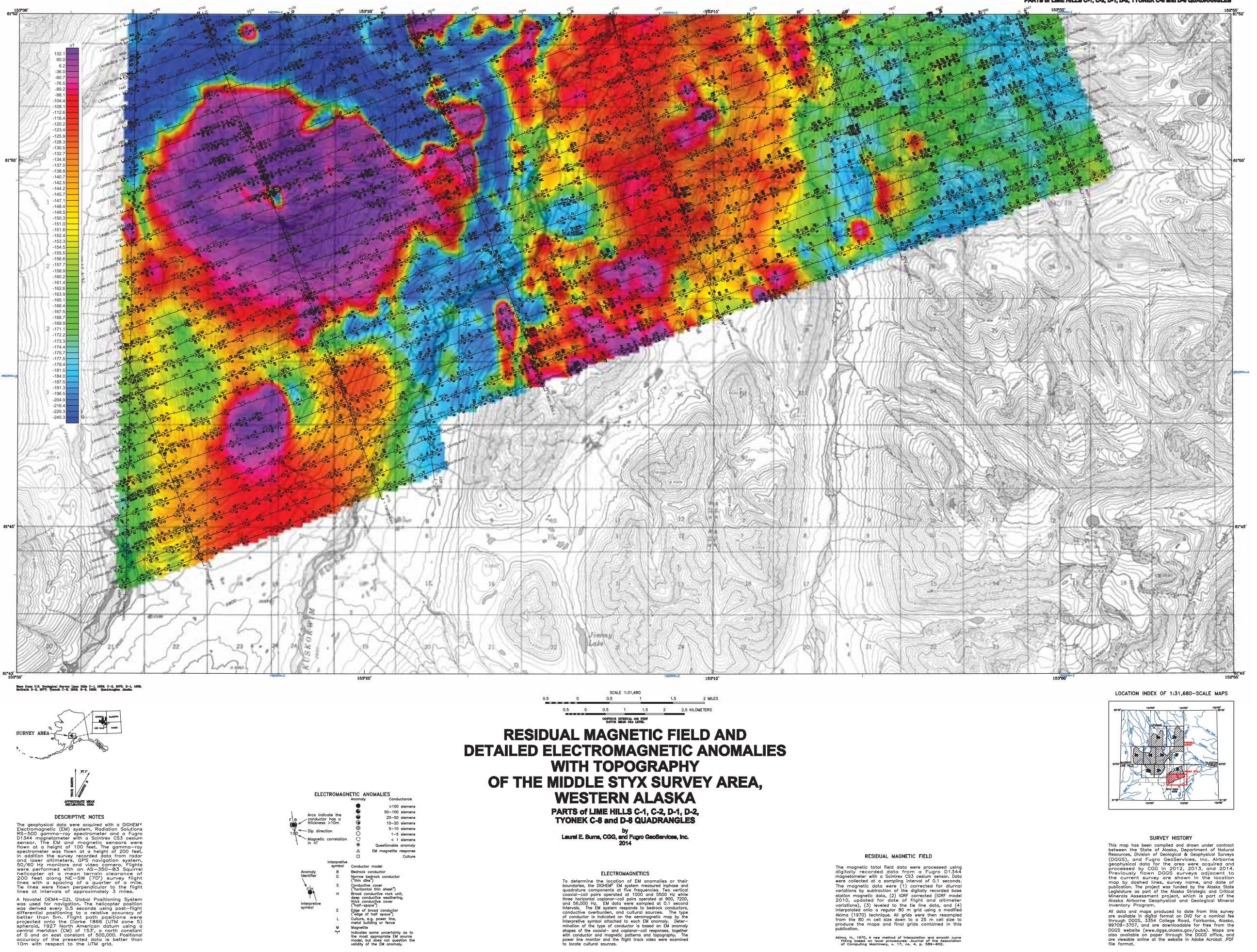




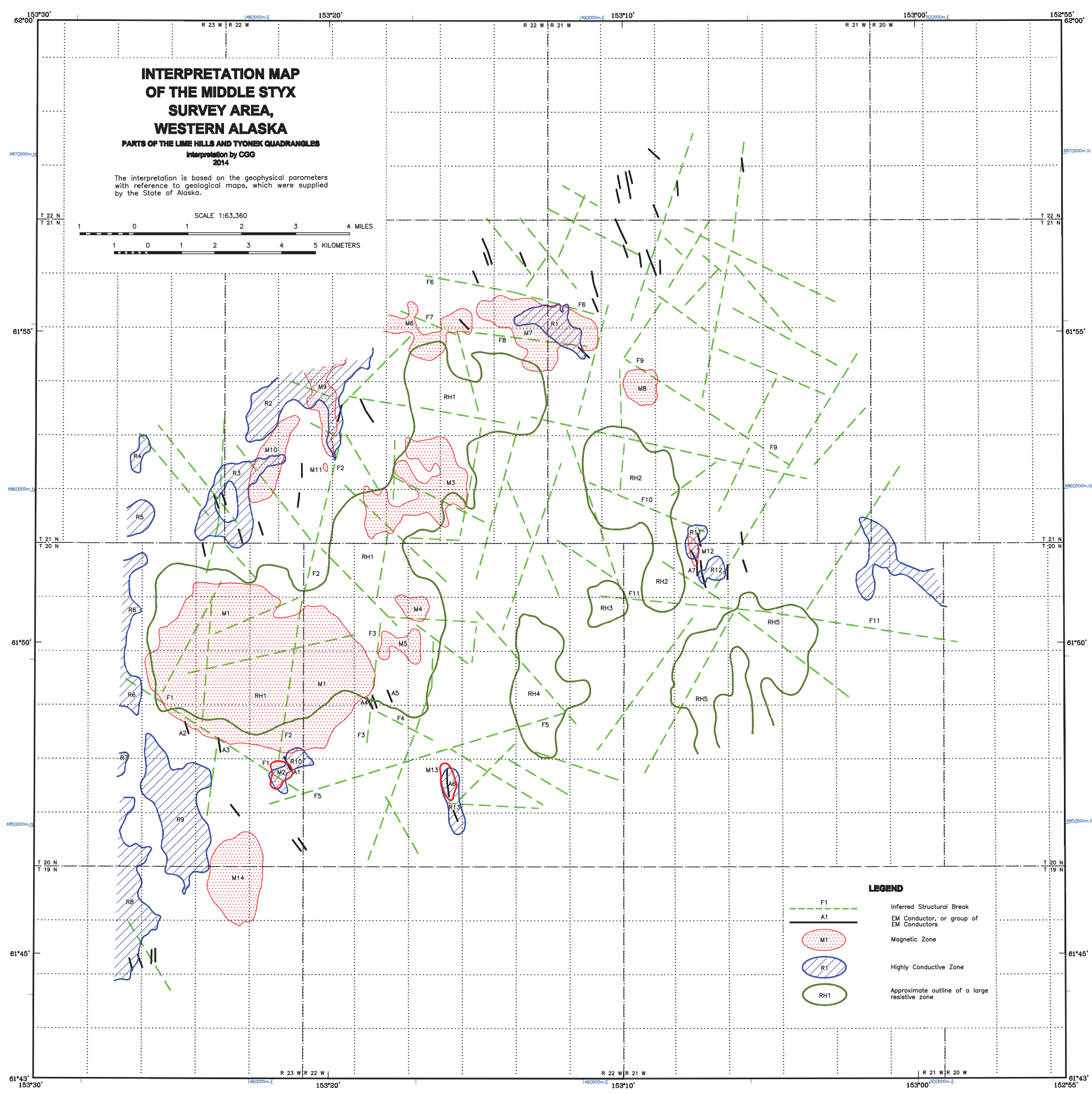




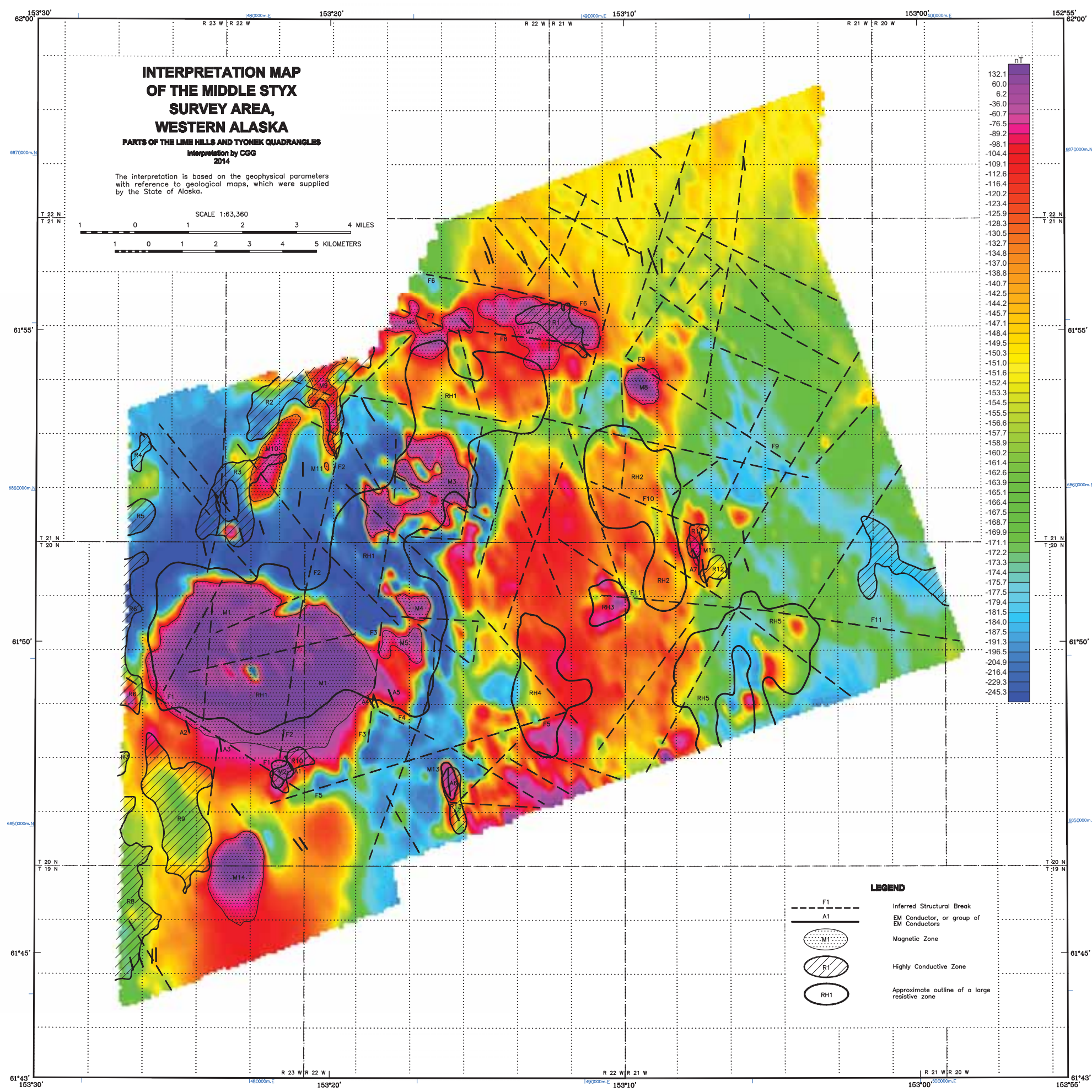




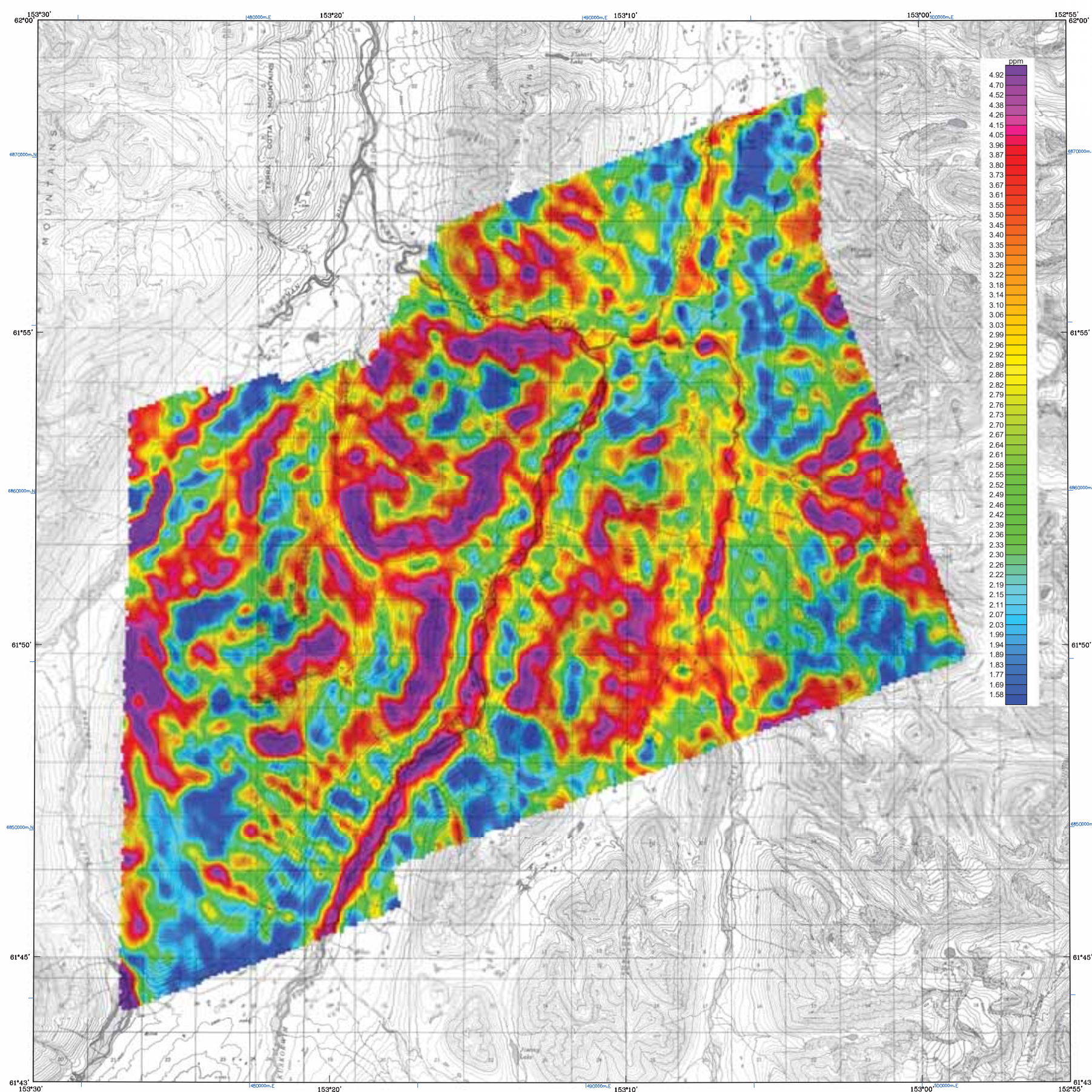

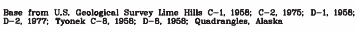

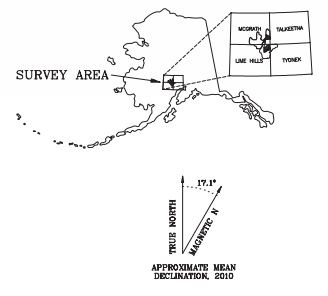

DESCRIPTIVE NOTES

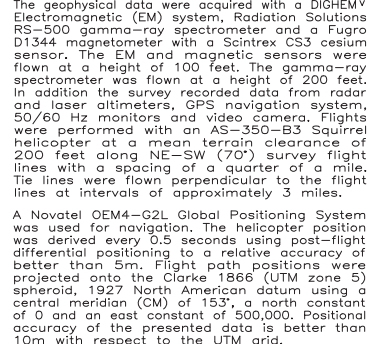

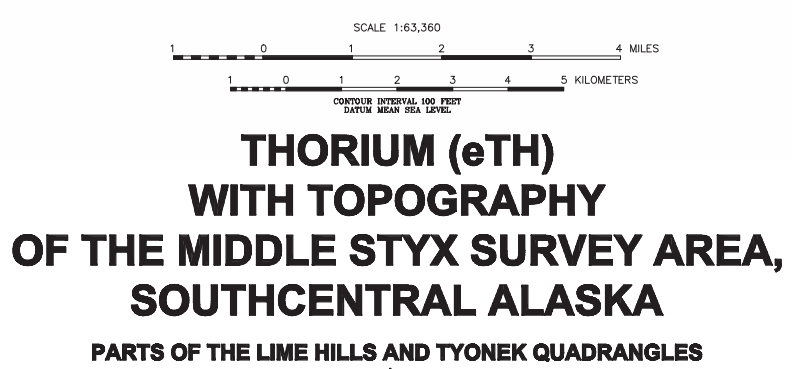

PARTS OF THE LME HILLS AND TYONEK QUADRANGLES

by
Laurel E. Bums, Fugro Arborne Surveys Corp., and Fugro GeoServices, Inc.
2013

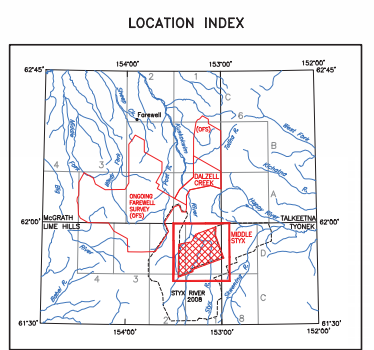

SURVEY HISTORY
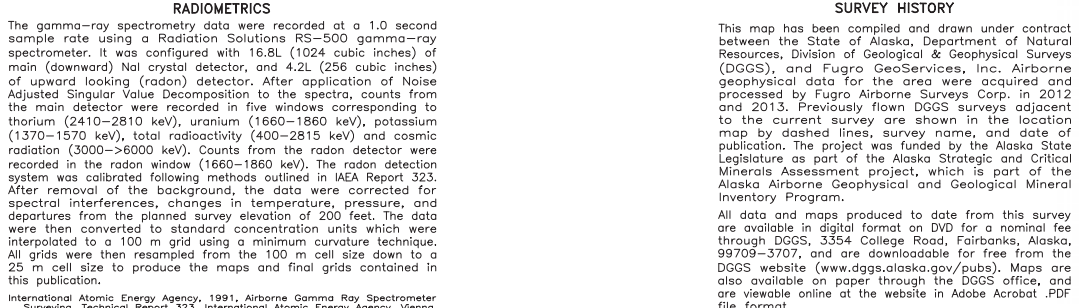


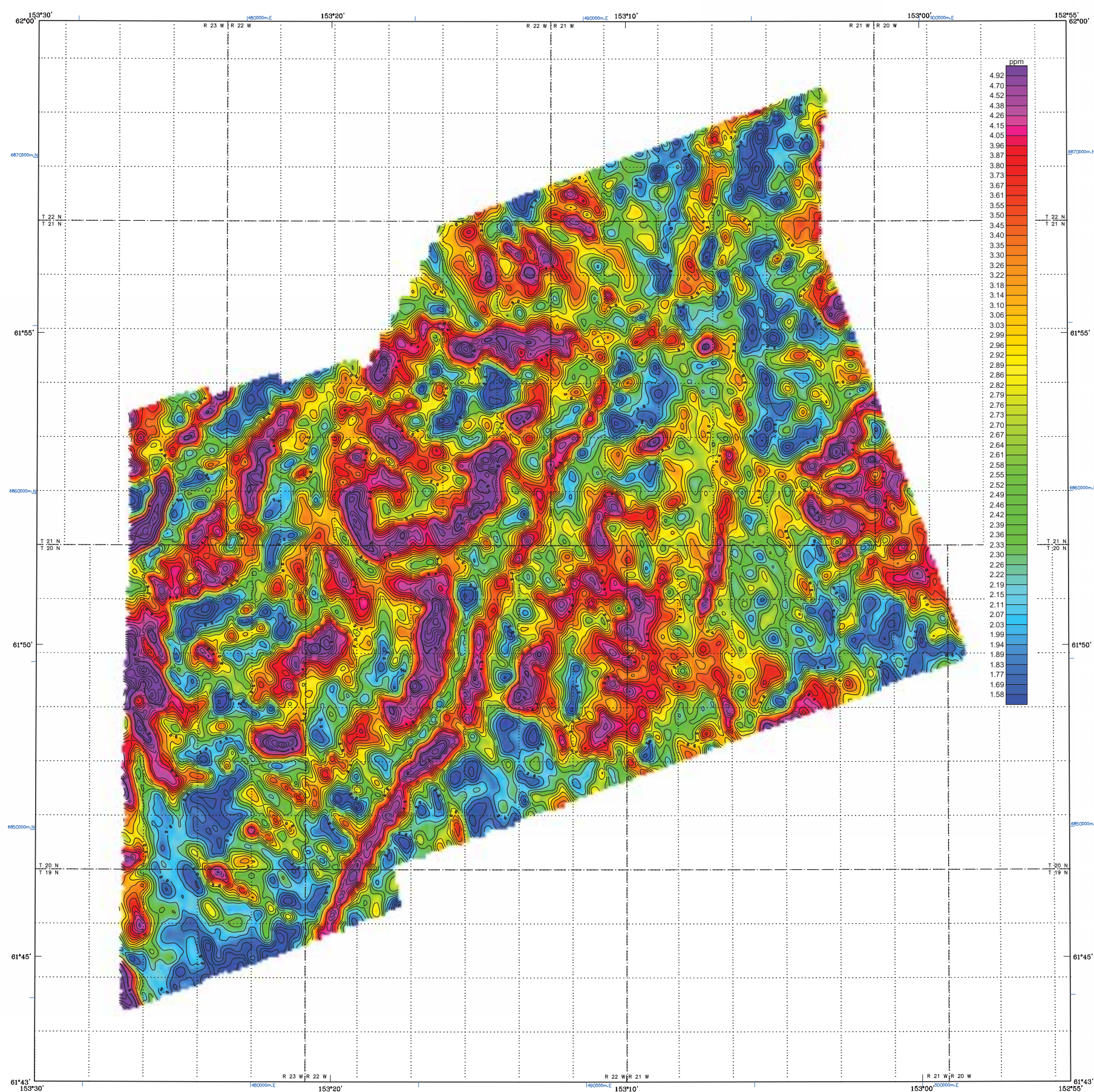

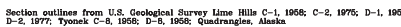
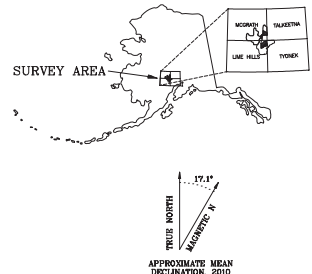

DESCRIPTIVE NOTES

The geophysical data, were acquired with a DIGHEMV
Electromagnetic (EM) system, Radiation Solutions
RS-500 gamma-ray spectrometer and a Fugro

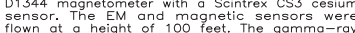

Spaddition the survey recorded data from radar
In and laser altimeters, GS navigation system
and

were performed with an $A S-350-33$ Squirre
helicopter at a mean terrain clearance o

lines with were flown perpendicular to the flight

A Novatel OEM4-G2L Global Positioning Syste
was used for navigation. The helicopter position
was derived every 0.5 seconds using post-fli

differential positioning to a relative accuracy
better than $5 m$. Flight path positions wer
projected onto the clacke 1866 (UTM zone

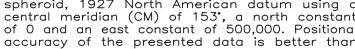

$10 \mathrm{~m}$ with respect to the UTM grid

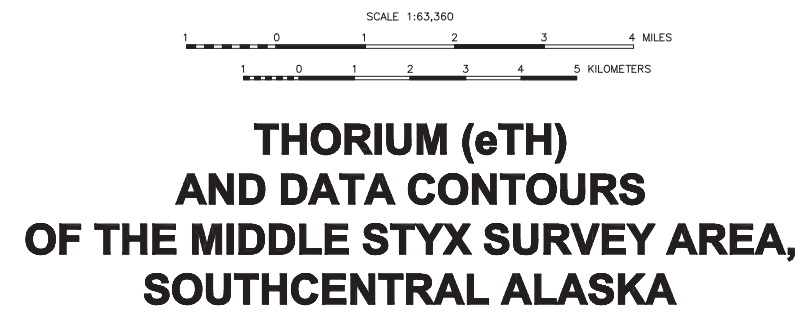

PARTS OF THE LME HILLS AND TYONEK QUADRANGLES

by
Laurel E. Bums, Fugro Arbome Surveys Corp., and Fugro GeoSenvices, Inc.
2013 RADIOMETRICS

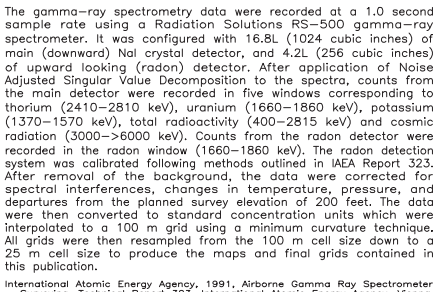

CONTOUR INTERVAL

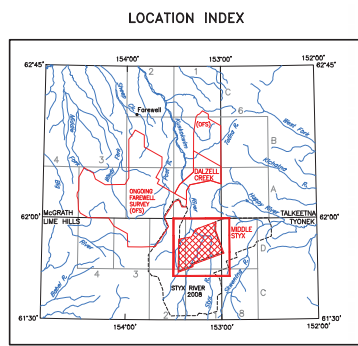

SURVEY HISTORY

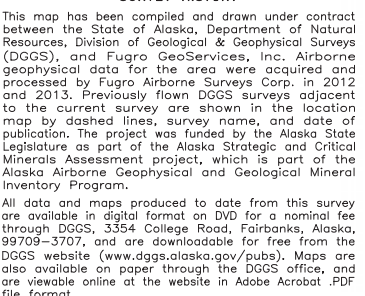




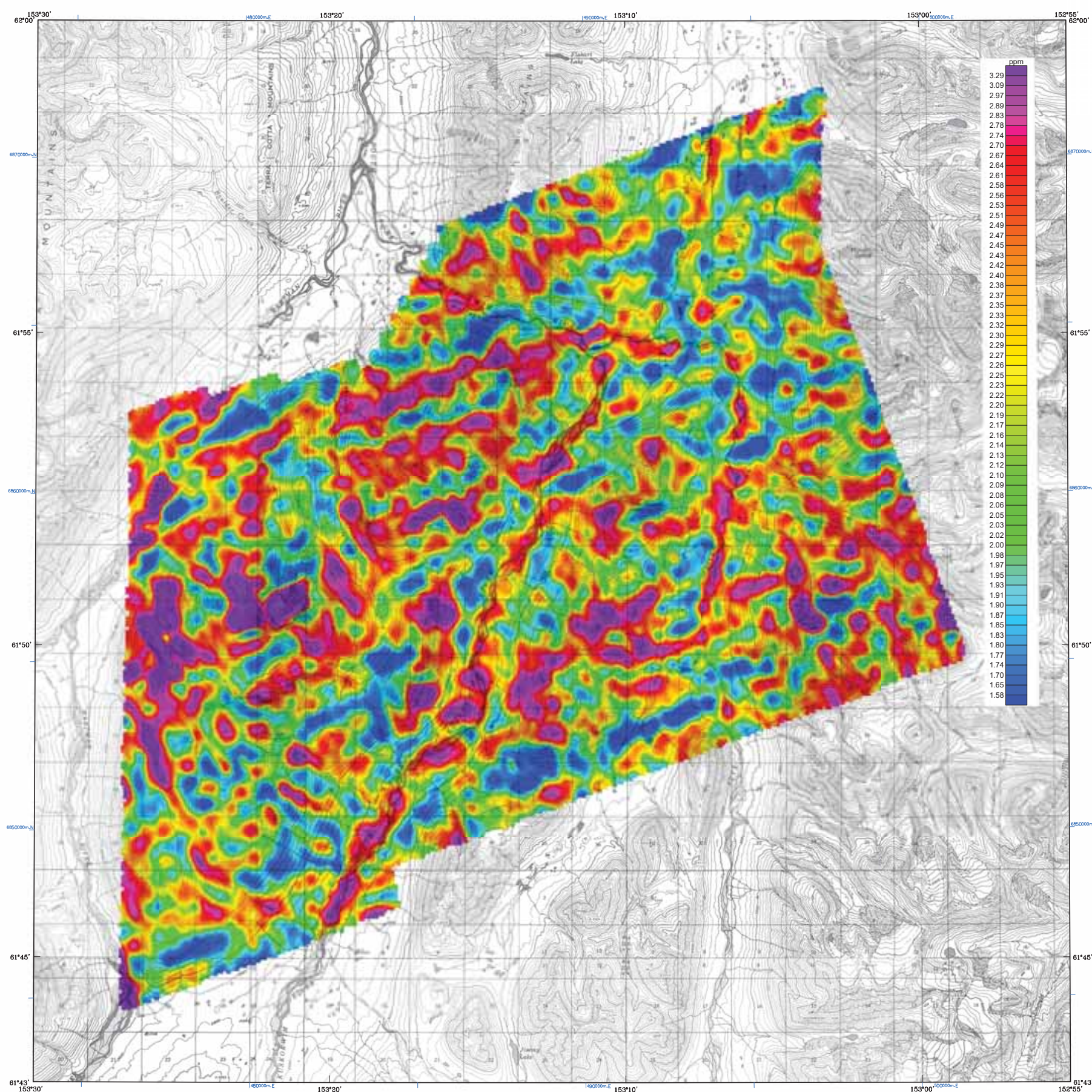

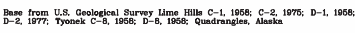

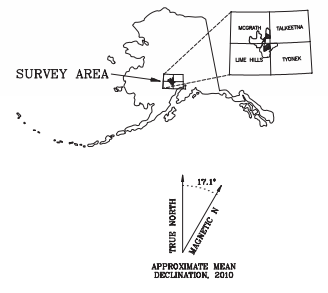

ESCRIPTIVE NOTES

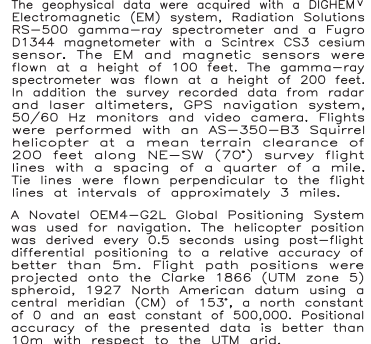

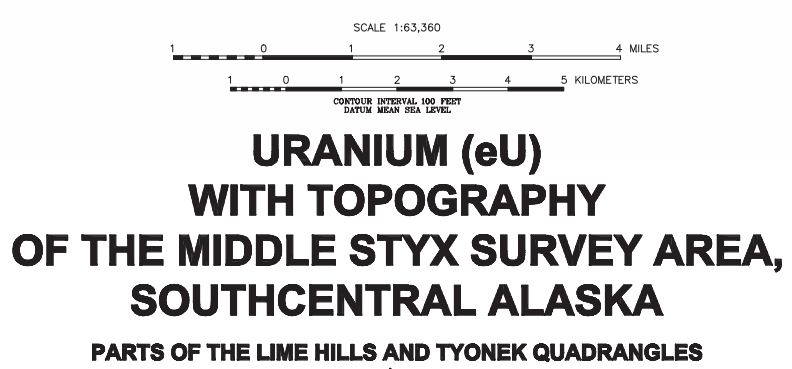

PARTS OF THE LME HILLS AND TYONEK QUADRANGLES

by
Laurel E. Bums, Fugro Arborne Surveys Corp., and Fugro GeoServices, Inc.
2013

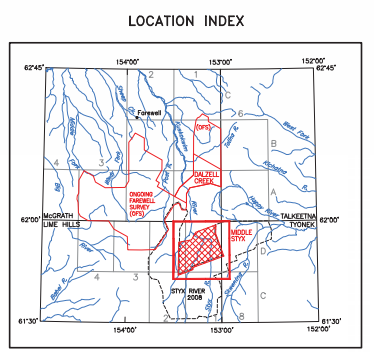

SURVEY HISTORY
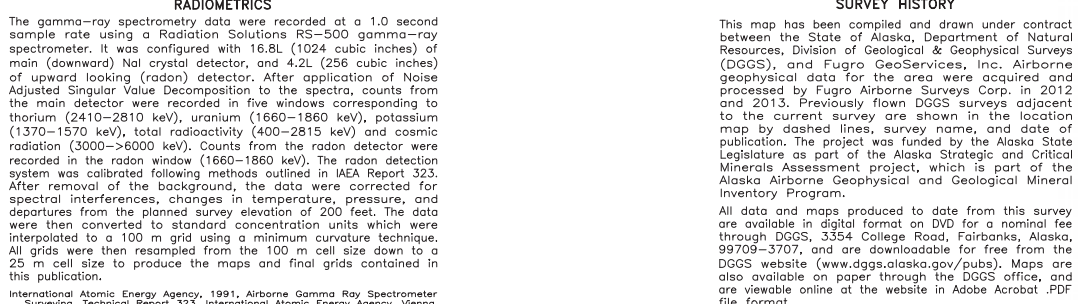


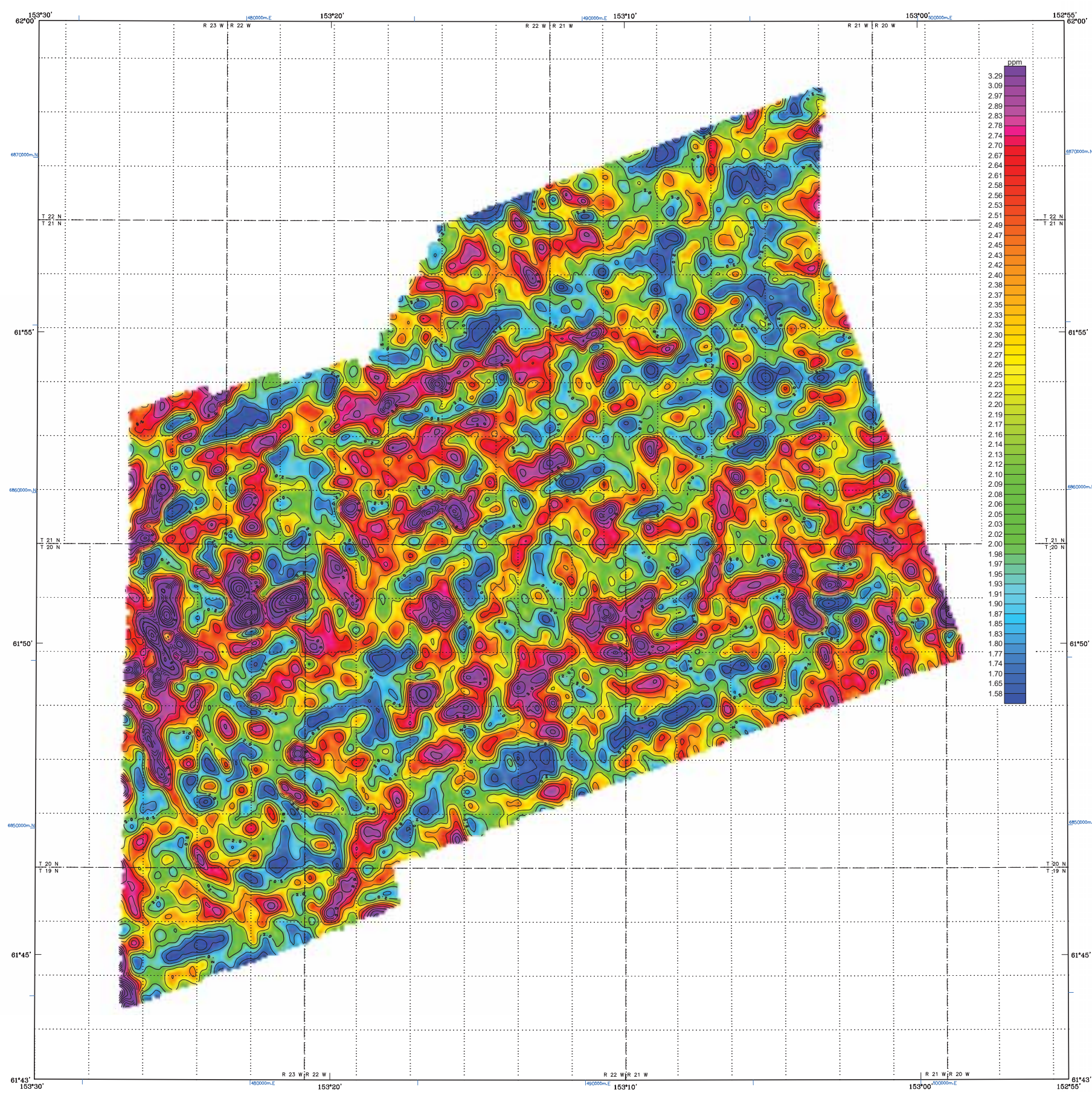

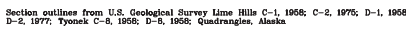
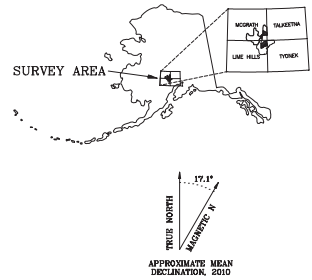

DESCRIPTIVE NOTES

The geophysical data, were acquired with a DIGHEMV
Electromagnetic (EM) system, Radiation Solutions
RS-500 gamma-ray spectrometer and a Fugro

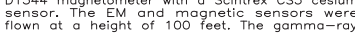

Speaddition the survey recorded data from radar
In and laser altimeters, GPS navigation system
and

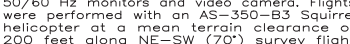

lines with a spacing of a quarter of a mile
Tie lines were flown perpendicular to the flight

A Novatel OEM4-G2L Global Positioning Syste
was used for navigation. The helicopter position
was derived every o 5 second using post-fligh

differential positioning to a relative accuracy
better than $5 m$. Flight path positions wer
projected onto the clacke 1866 (UTM zone

sphroid, 1927 North American datum using
central meridian (CM) of 153 . . a north constant
of 0 and an east constant of 500,000 . Poititional
accuracy of the presented data is better than

$10 \mathrm{~m}$ with respect to the UTM grid

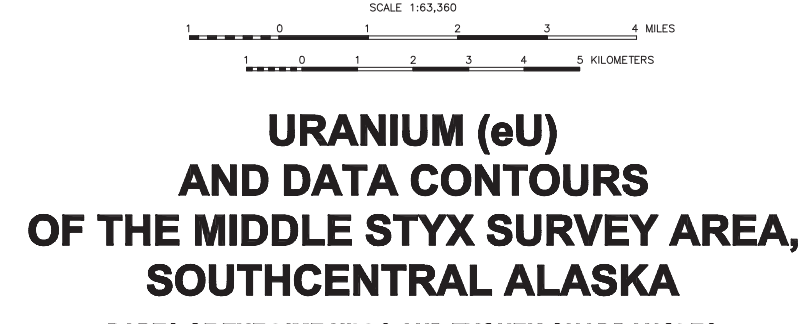

PARTS OF THE LME HILLS AND TYONEK QUADRANGLES

by
Laurel E. Bums, Fugro Arbome Surveys Corp., and Fugro GeoSenvices, Inc.
2013 RADIOMETRICS

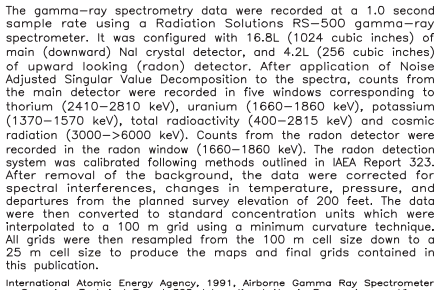

CONTOUR INTERVAL

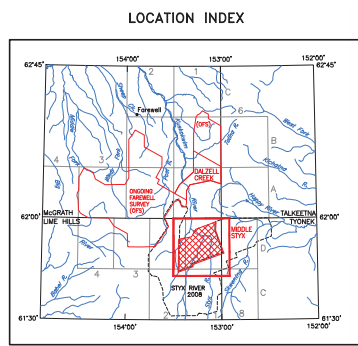

SURVEY HISTORY

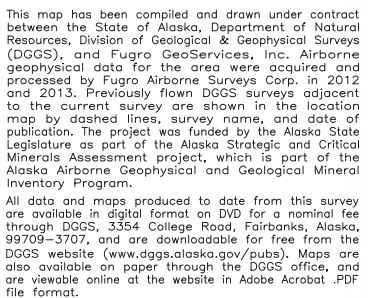




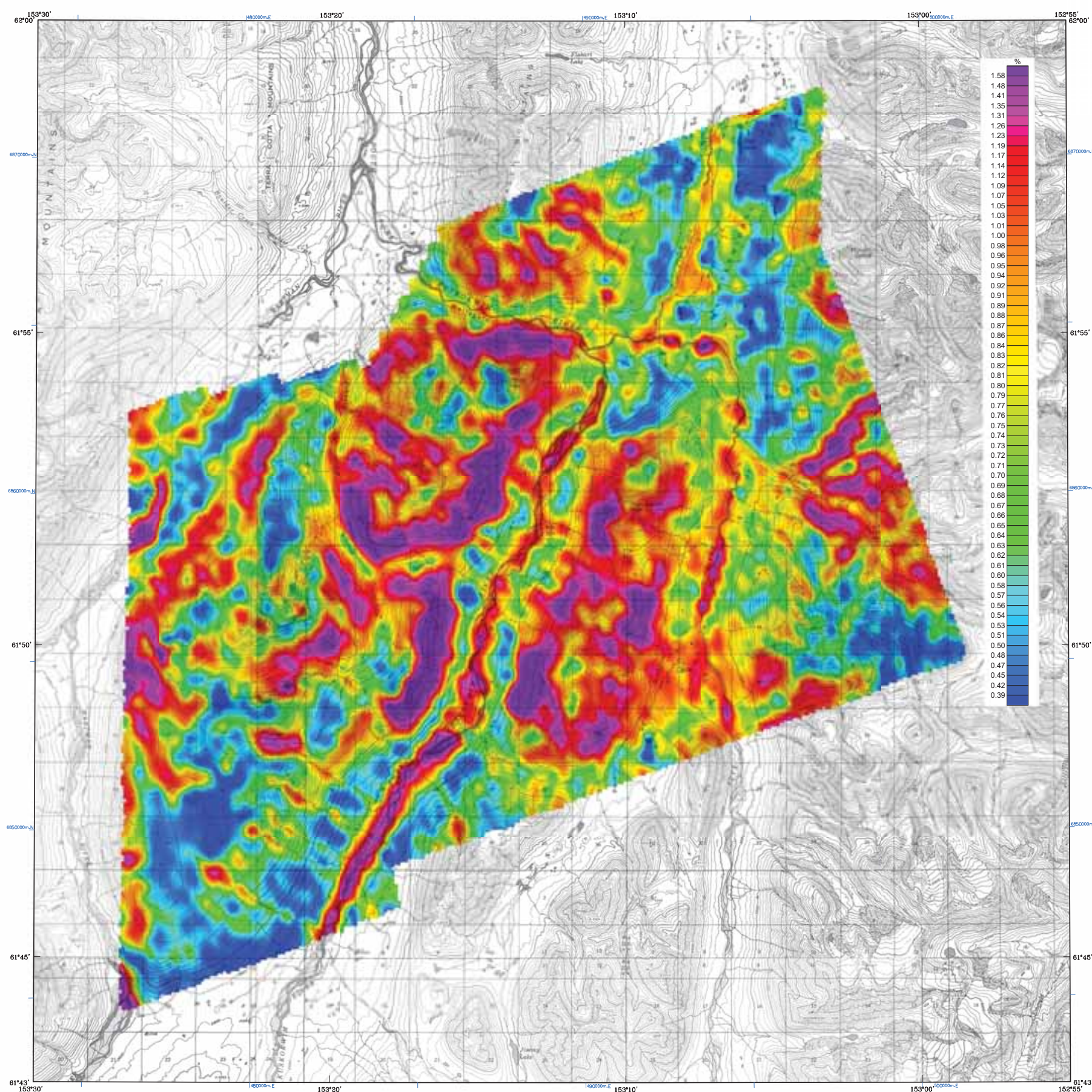

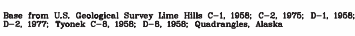

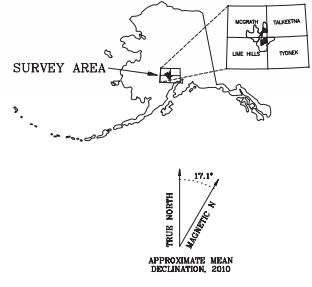

ESCRIPTIVE NOTES

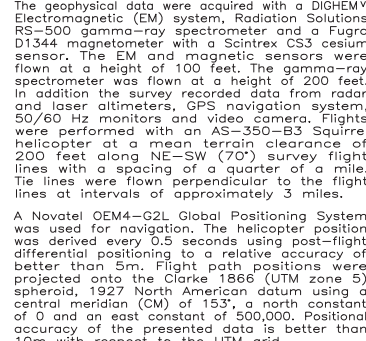

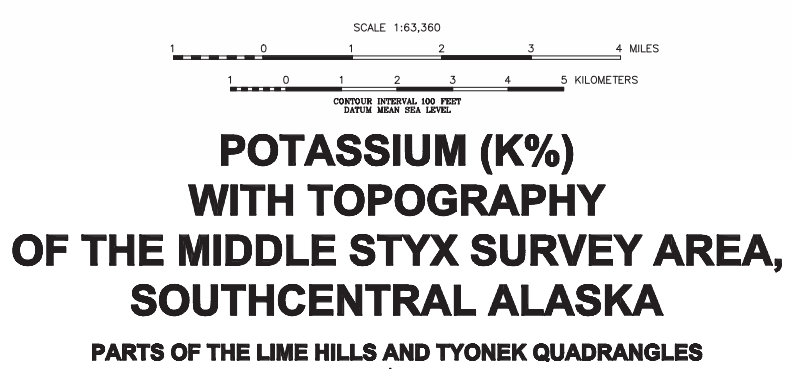

PARTS OF THE LME HILLS AND TYONEK QUADRANGLES

Laurel E. Burns, Fugro Artome Surveys Corp., and Fugro GeoServices, Inc.

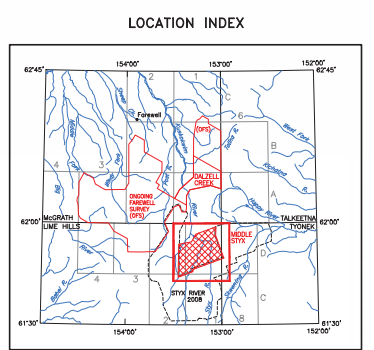

SURVEY HISTORY
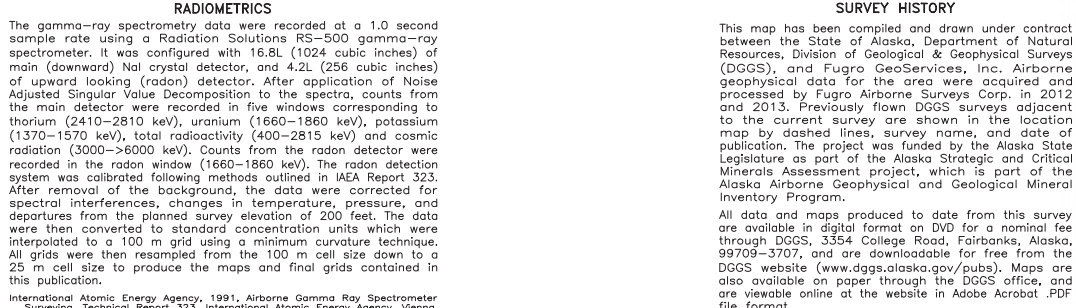


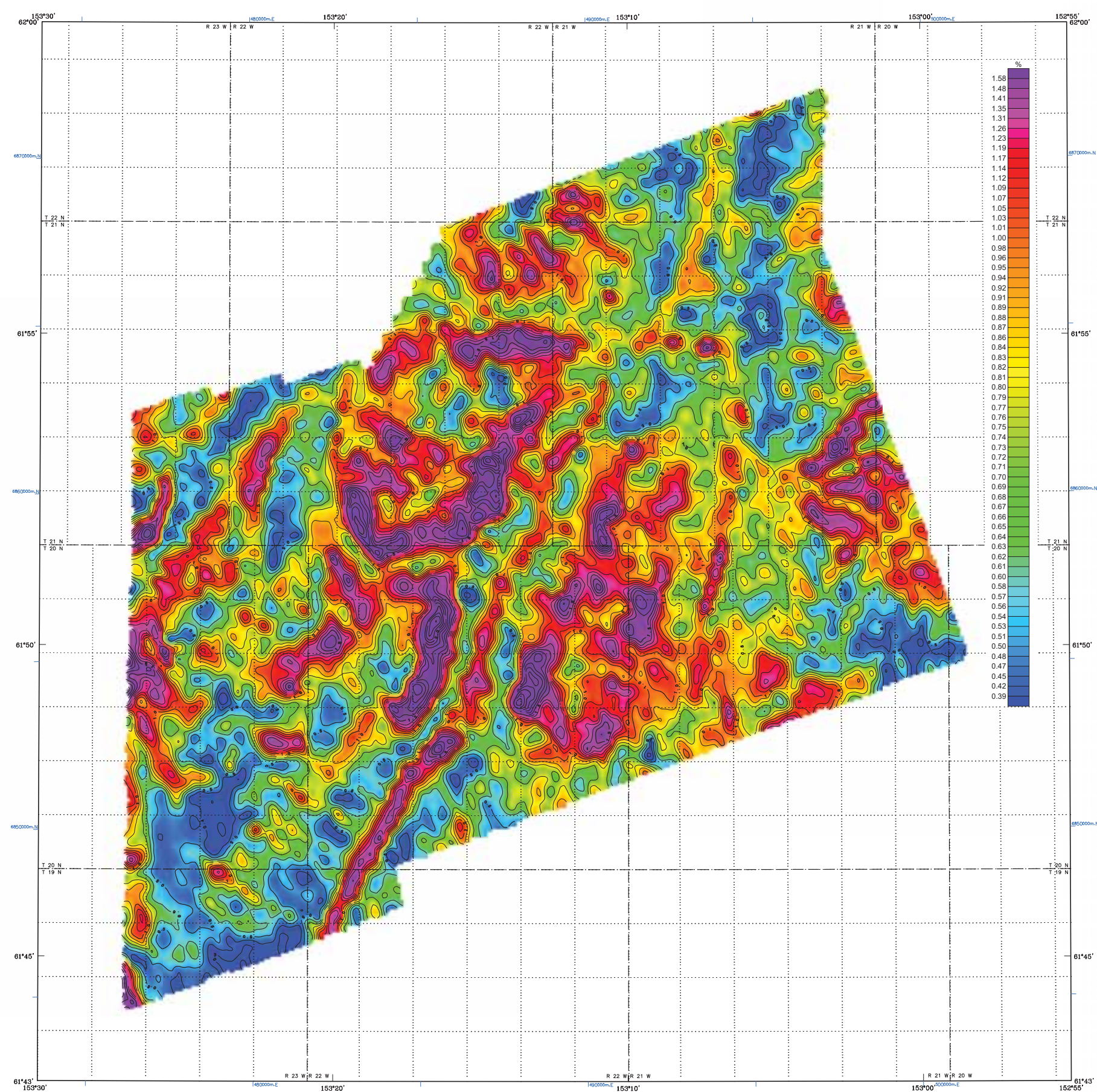

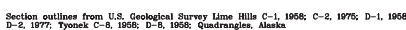
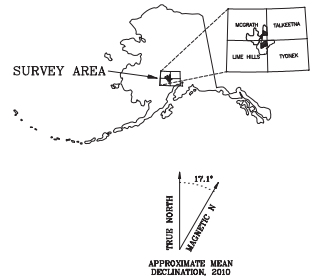

DESCRIPTIVE NOTES

The geophysical data, were acquired with a DIGHEMV
Electromagnetic (EM) system, Radiation Solutions
RS-500 gamma-ray spectrometer and a Fugro

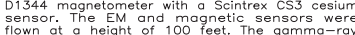

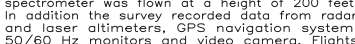

were performed with an AS-350-B3 Squirre
helicopter at a mean terrain clearance o
200 fet at

lines with a spacing of a quarter of a mile
Tie lines were flown perpendicular to the flight

A Novatel OEM4-G2L Global Positioning Syste
was used for navigation. The helicopter position
was derived every 5 s seconds using post-fligh

differential positioning to a relative accuracy
better

spheroid, 1927 North American datum using
central meridian (M) of $153^{\circ}$, north constan
of

gccuracy of the presented data is better than
$10 \mathrm{~m}$ with repect to the UTM grid.

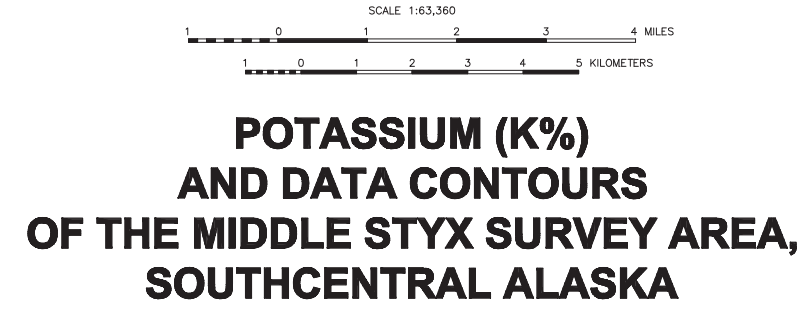

PARTS OF THE LME HILLS AND TYONEK QUADRANGLES

by
Laurel E. Bums, Fugro Arbome Surveys Corp., and Fugro GeoSenvices, Inc.
2013 RADIOMETRICS

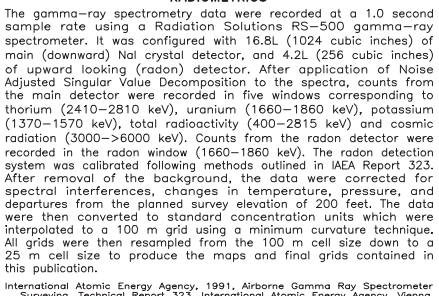

CONTOUR INTERVAL

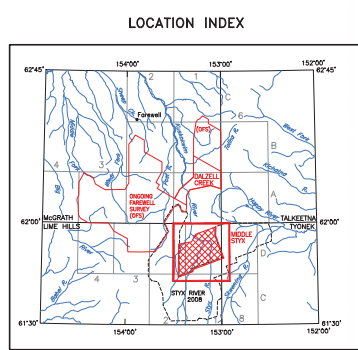

SURVEY HISTORY

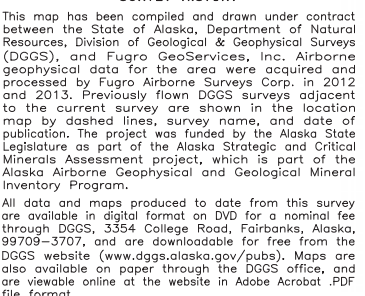




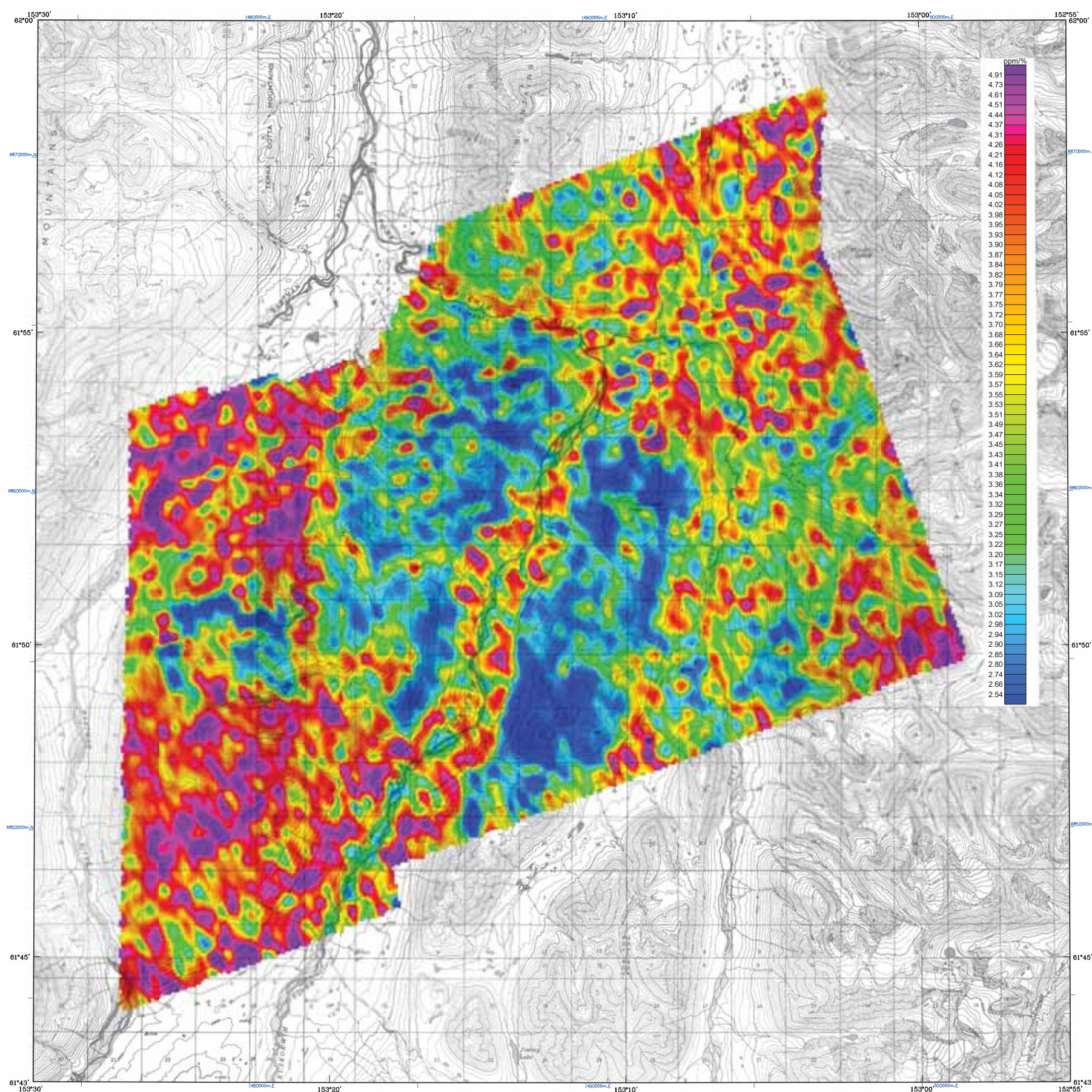

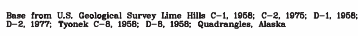

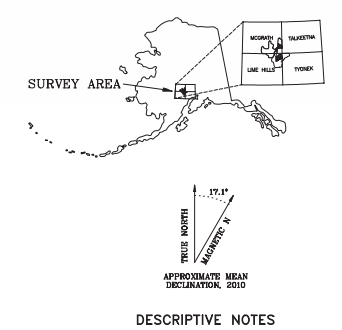

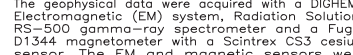
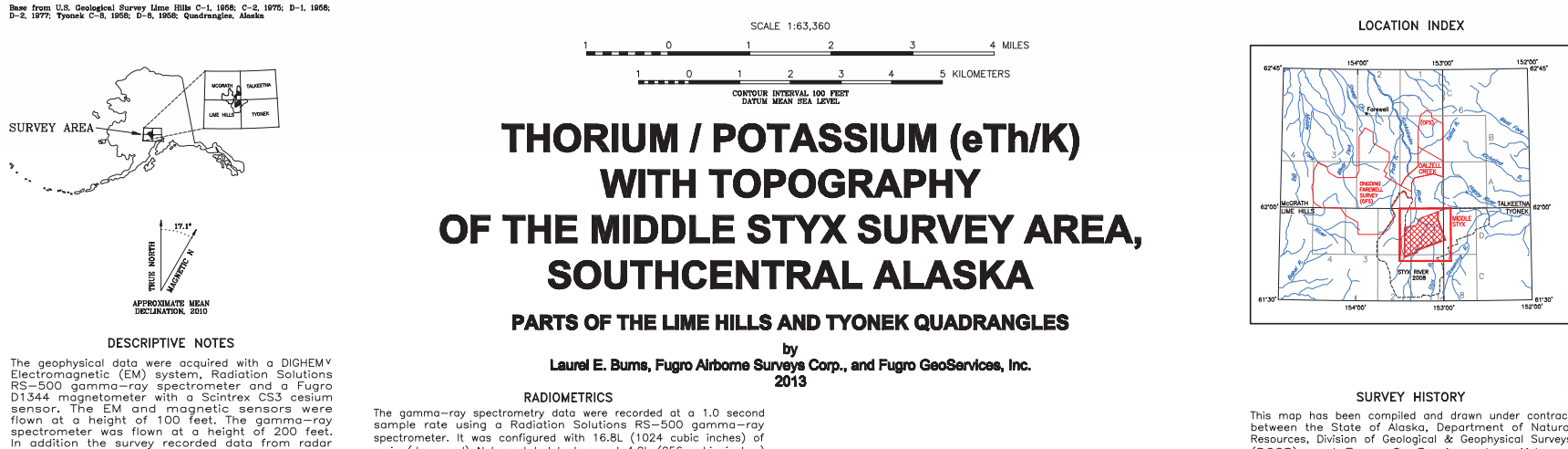

Laurel E. Bums, Fugro Airbome Surveys Corp., and Fugro GeoServices, Inc.
2013

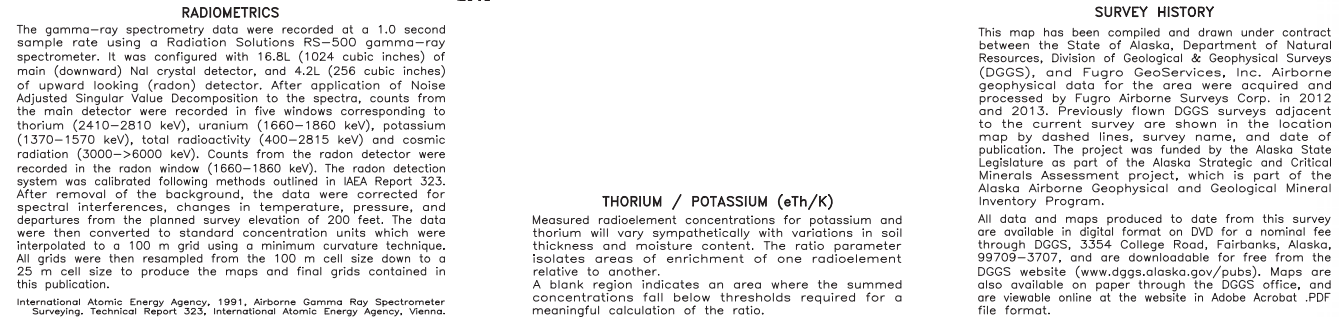




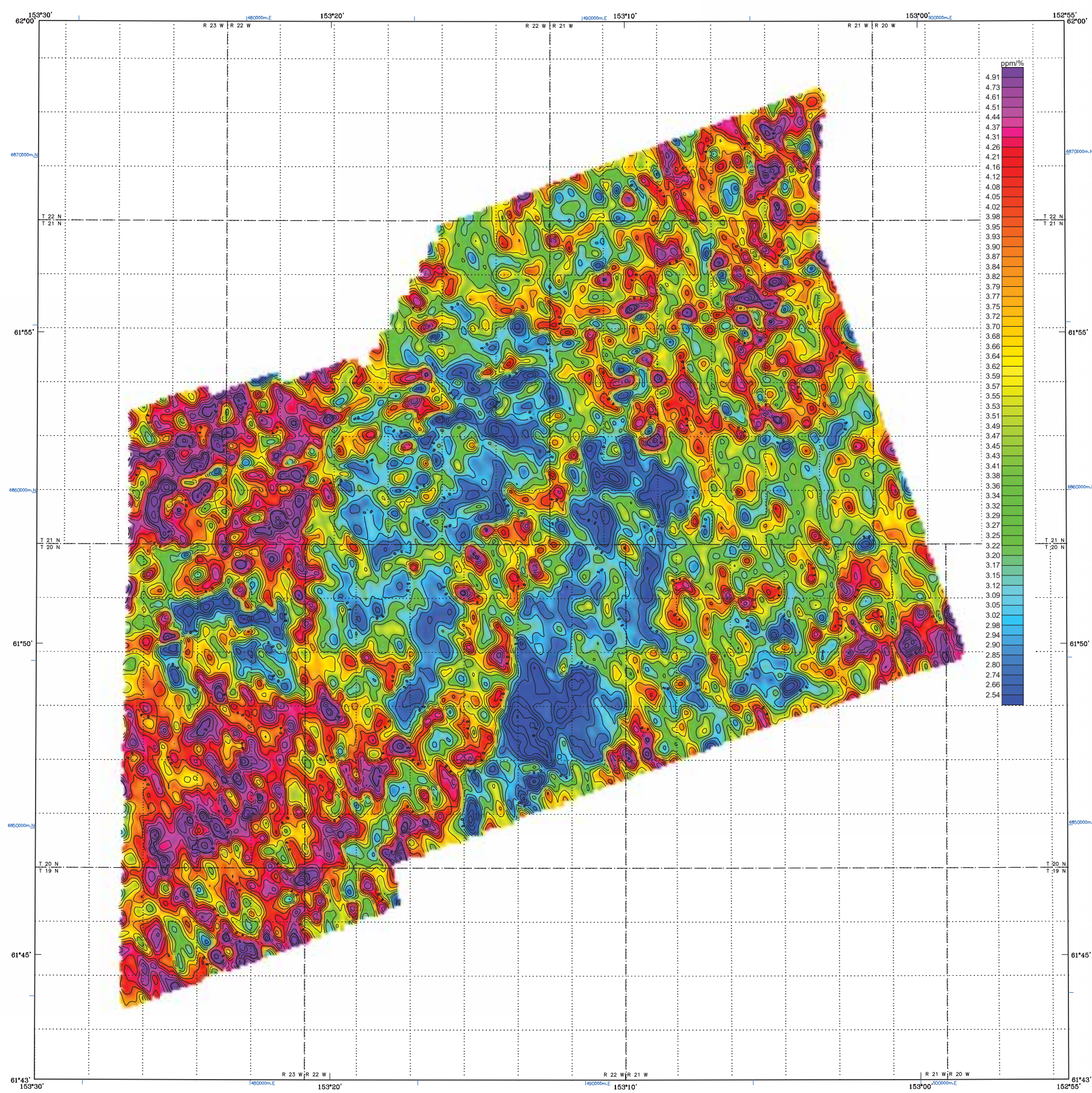

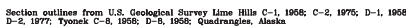
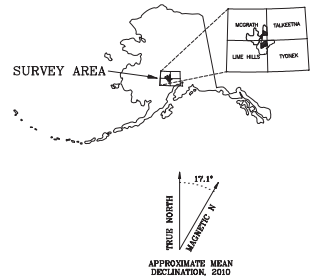

DESCRIPTIVE NOTES

The geophysical data were acquired with a DIGHEMV
Electromagnetic (EM) systemi Radiation Solutions
RS-500 gamma-ray spectrometer and a Fugro

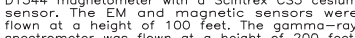

In addition the survey recorded gata from rada
and laser altimeters, GPS navigation system.
50 .

were performed with an $A S-350-B 3$ Squirre
helicopter at a mean terrain clearance o

lines with a spacing of a quarter of a mile
Tie lines were flown perpendicular to the flight

A Novatel OEM4-G2L Global Positioning Syste
was used for

differential positioning to a relative accuracy
better than $5 m$. Flight path positions wer
projected onto the Clarke 1866 (UTM zone

spheroid, 1927 North American datum using
central meridian (CM) of 153 . a north constant
of 0 and an east constant of 500,000 . Position

gccuracy of the presented data is better than
$10 \mathrm{~m}$ with respect to the UTM grid

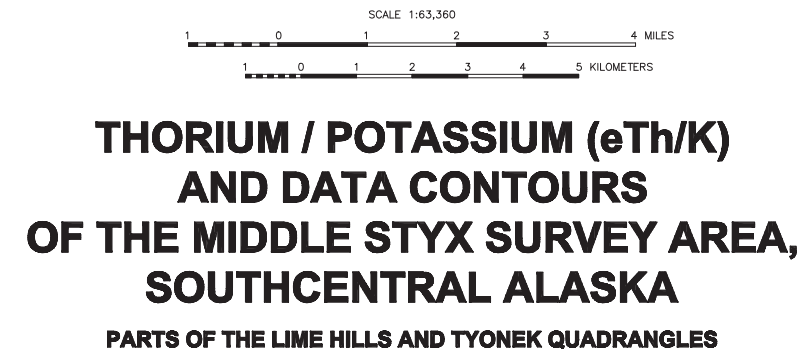

by
Laurel E. Bums, Fugro Arbome Surveys Corp., and Fugro GeoServices, Inc.
2013 RADIOMETRICS

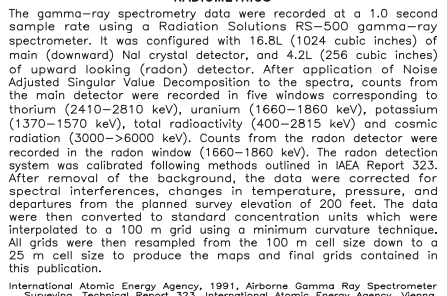

THORIUM / POTASSIUM (eTh/K)

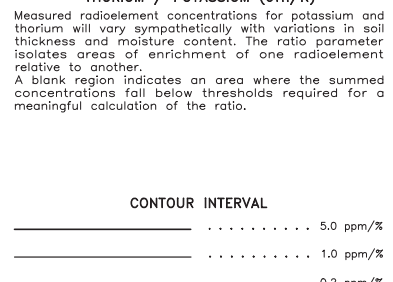

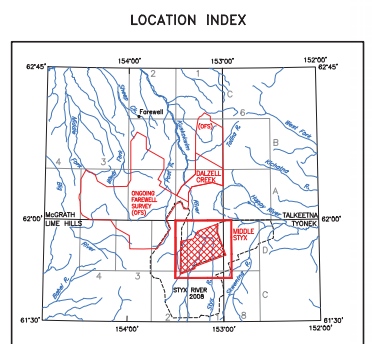

SURVEY HISTORY

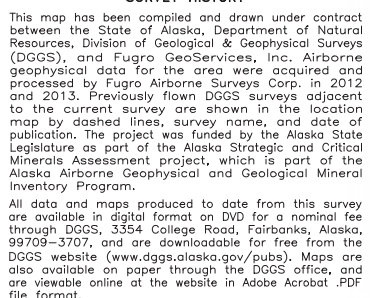




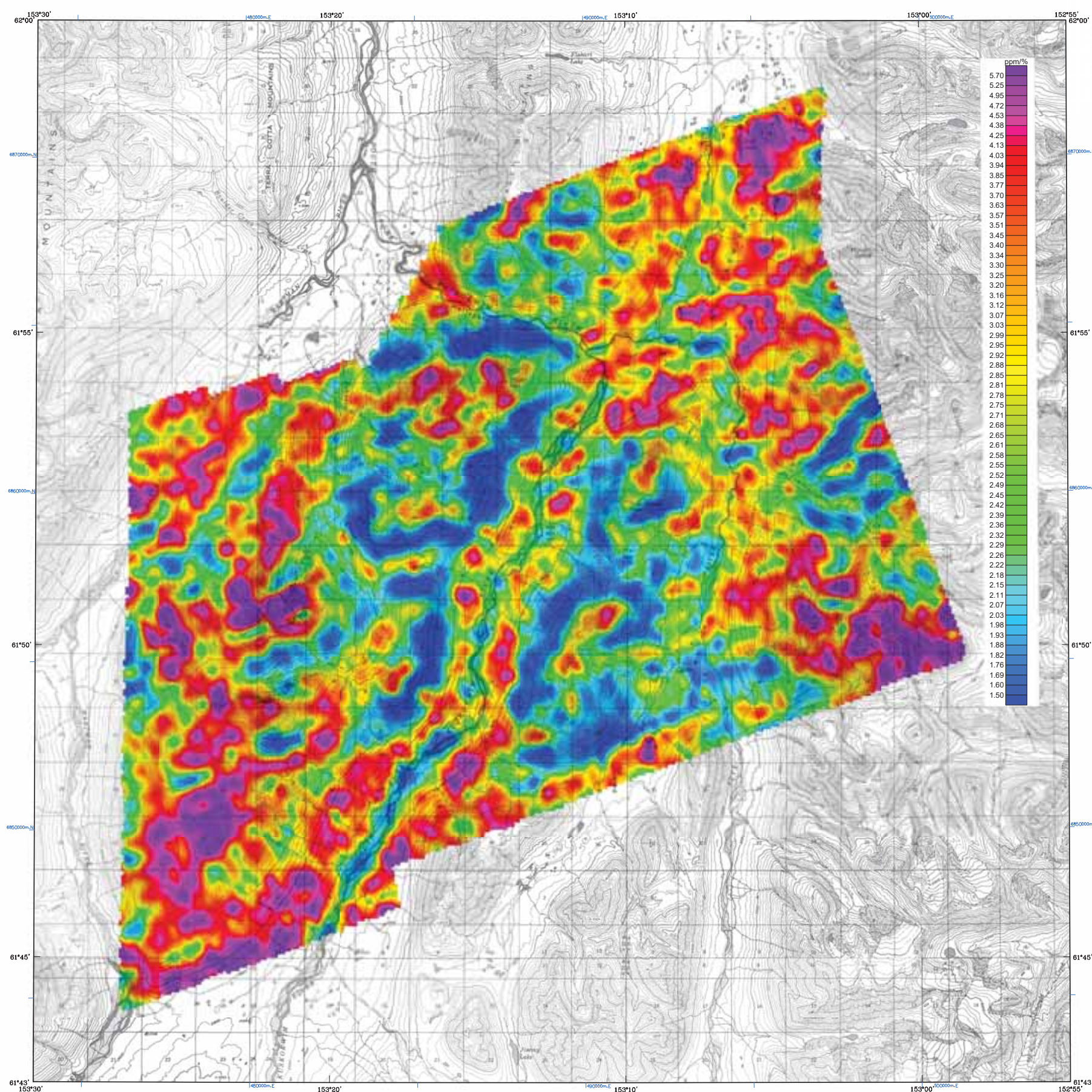

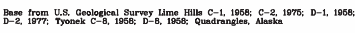

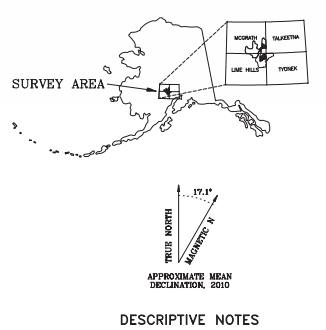

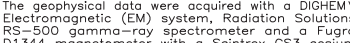
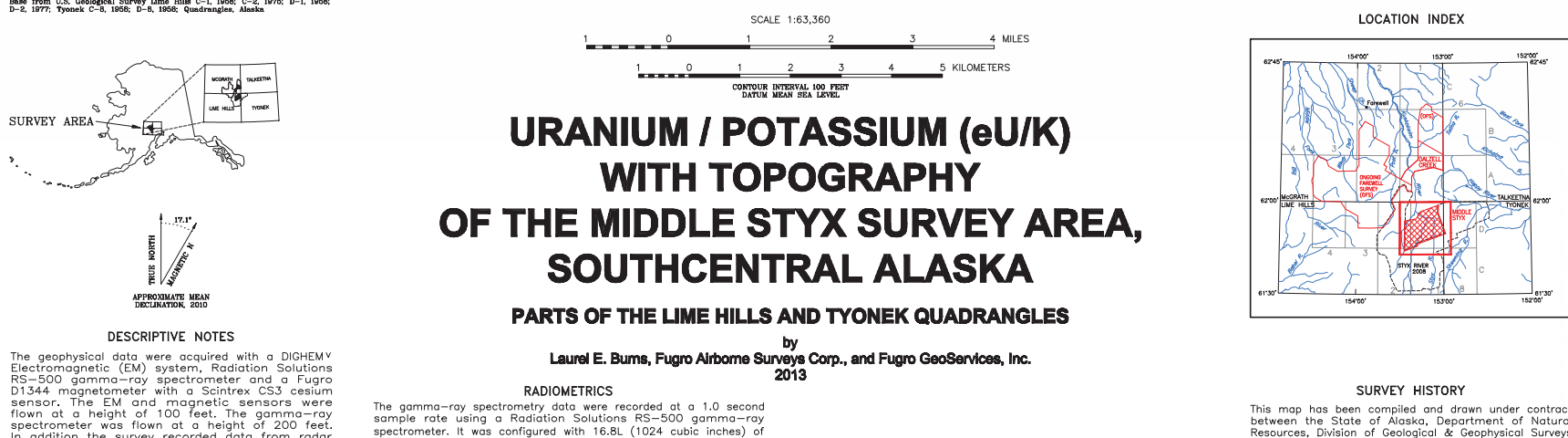

Laurel E. Bums, Fugro Airbome Surveys Corp., and Fugro GeoServices, Inc.
2013 RADIOMETRICS

SURVEY HISTORY

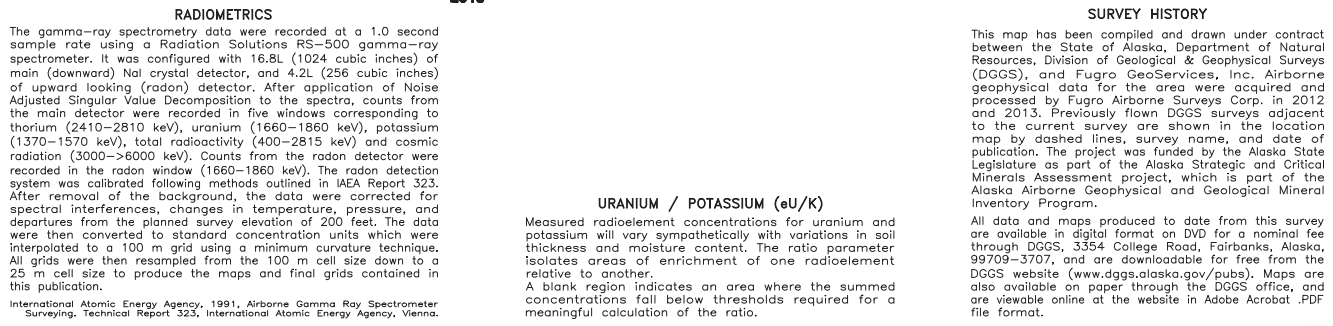




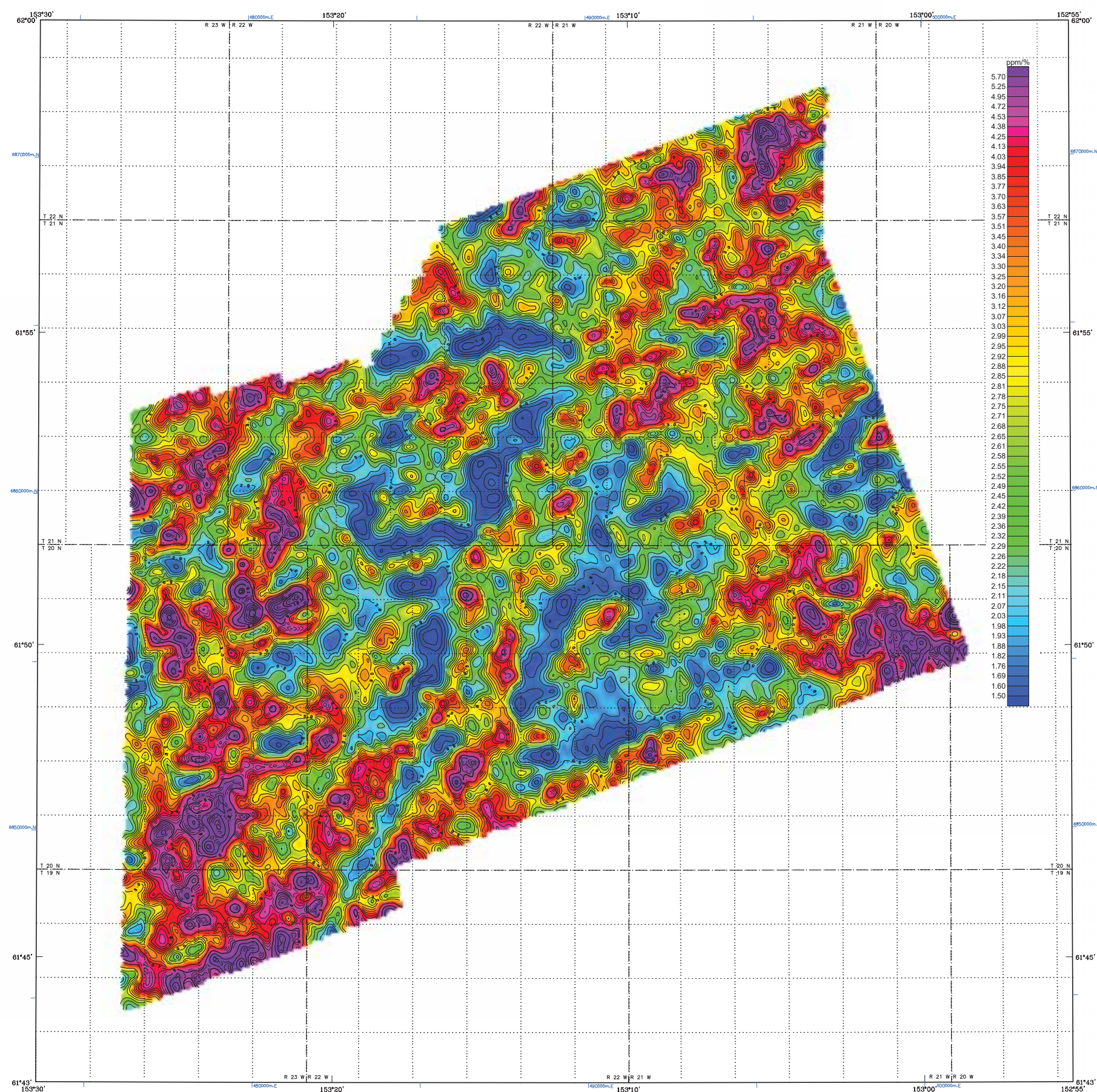

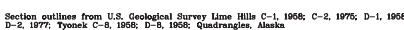

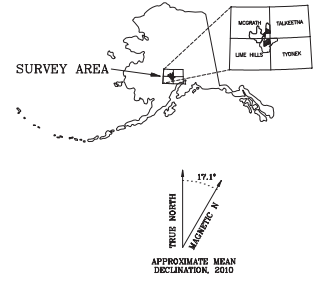

DESCRIPTIVE NOTES

The geophysical data, were acquired with a DIGHEMV
Electromagnetic (EM) system, Radiation Solutions
RS-500 gamma-ray spectrometer and a Fugro

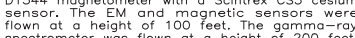

In addition the survey recorded data from radar
and laser altimeters, GPS navigation system
50 .

were performed with an AS-350-B3 Squirre
helicopter at a mean terrain clearance o

lines with a spacing of a quarter of a mile
Tie lines were flown perpendicular to the flight

A Novatel OEM4-G2L Global Positioning Syste
was used for navigation. The helicopter position
was derived every o 5 seconds using post-fligh

differential positioning to a relative accuracy
better than $5 \mathrm{~m}$. Flight path positions wer
projected onto the clarke 1866 (UTM zone

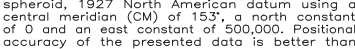

$10 \mathrm{~m}$ with respect to the UTM gris better than

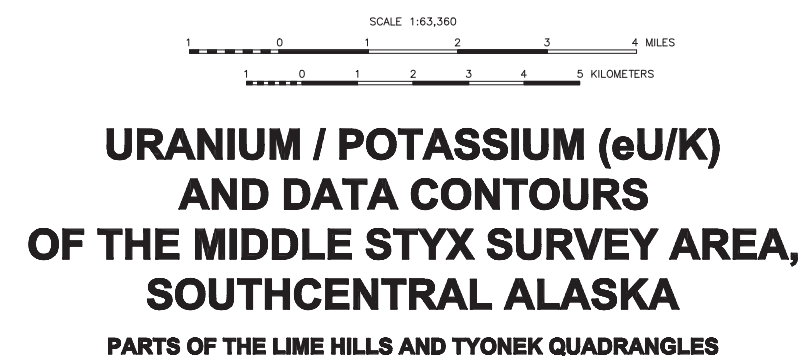

by
Laurel E. Bums, Fugro Arbome Surveys Corp., and Fugro GeoServices, Inc.
2013 RADIOMETRICS

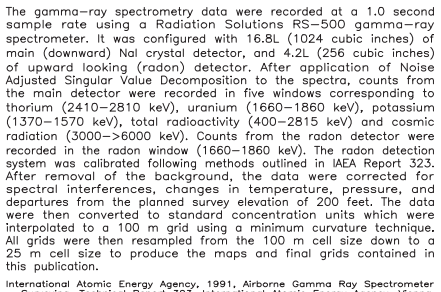

URANIUM / POTASSIUM (eU/K)

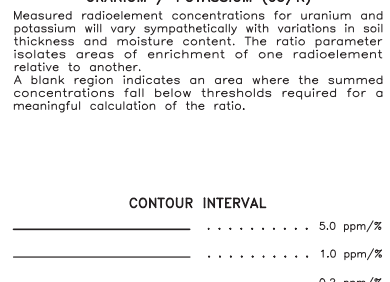

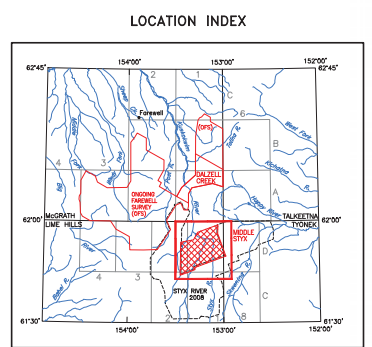

SURVEY HISTORY

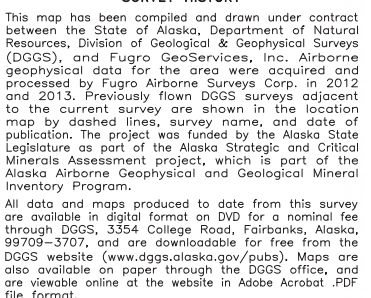




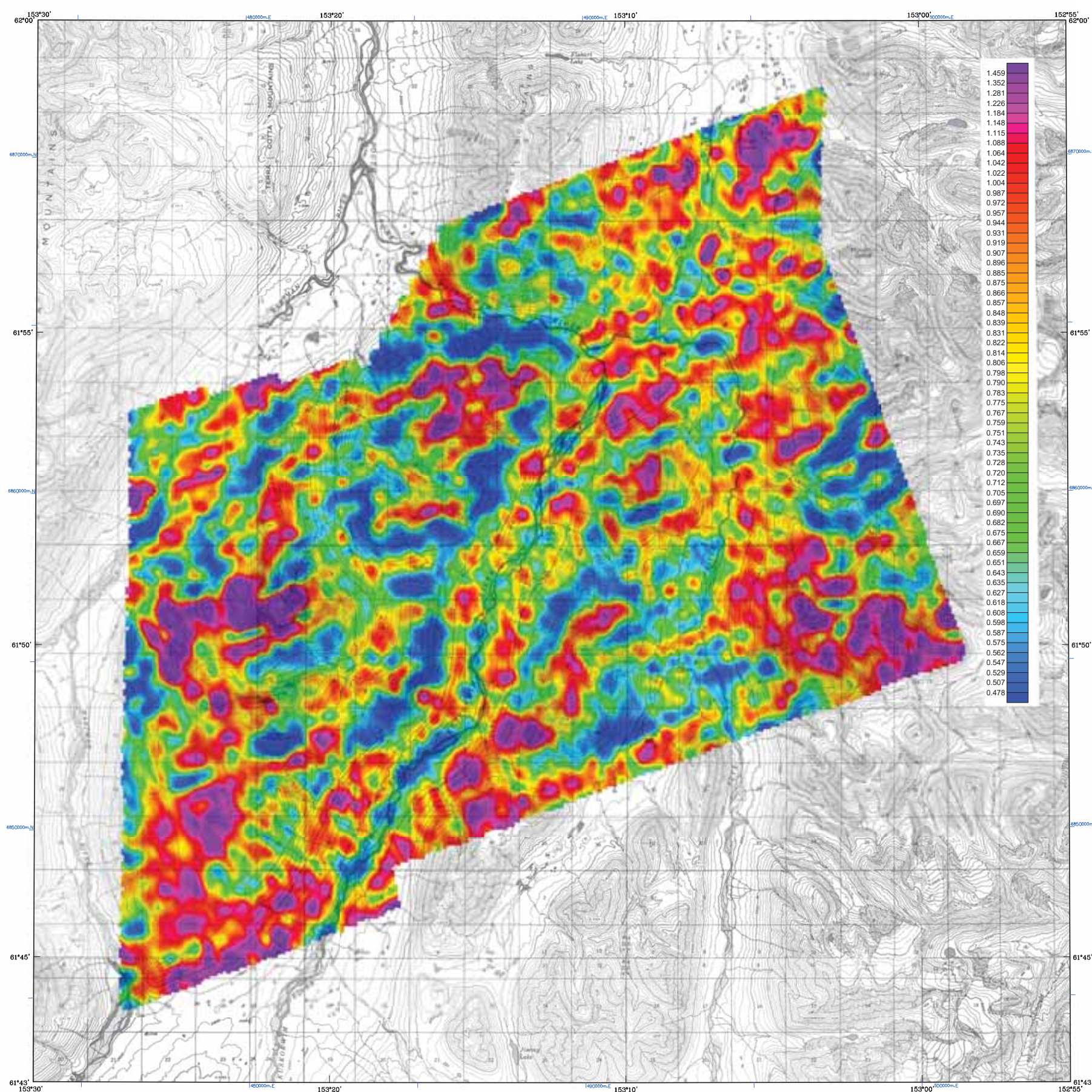

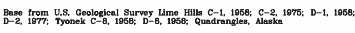

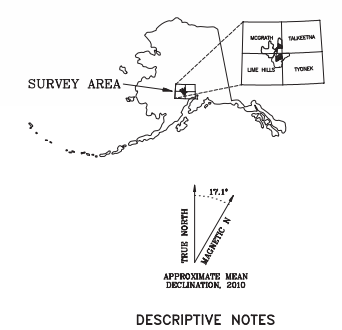

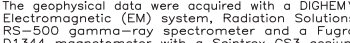
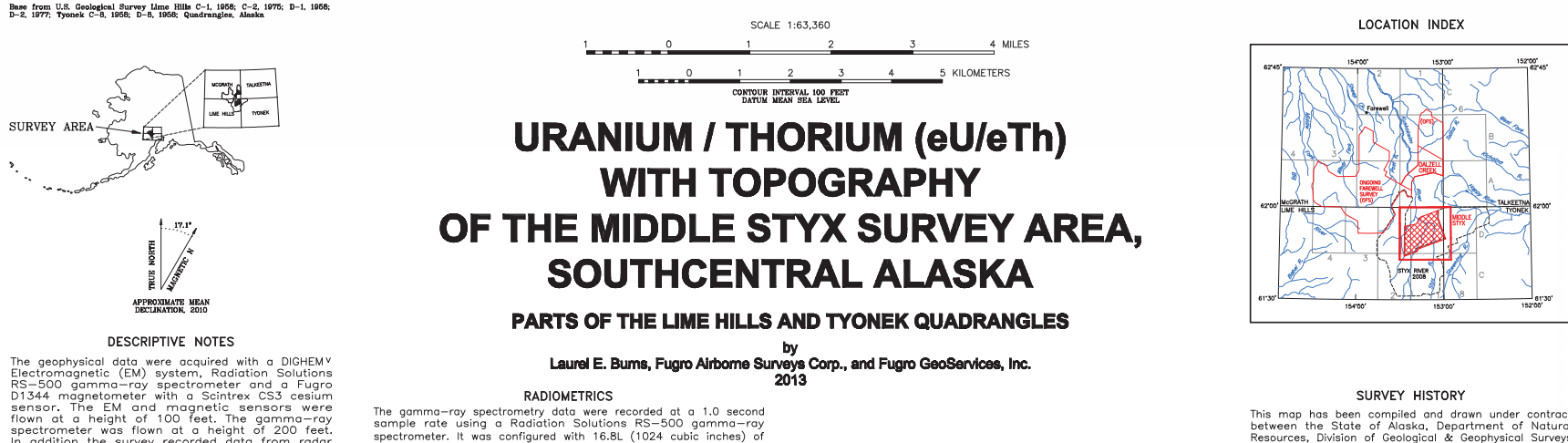

Laurel E. Bums, Fugro Airbome Surveys Corp., and Fugro GeoSenvices, Inc. RADIOMETRICS

SURVEY HISTORY

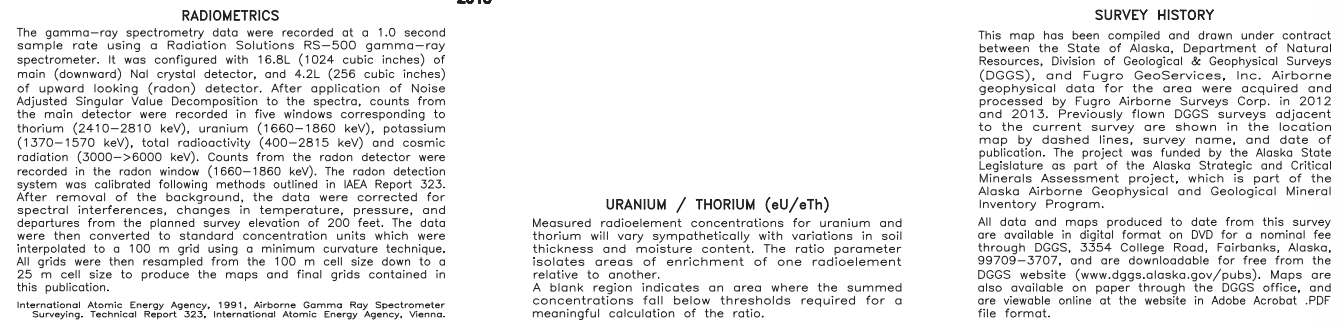




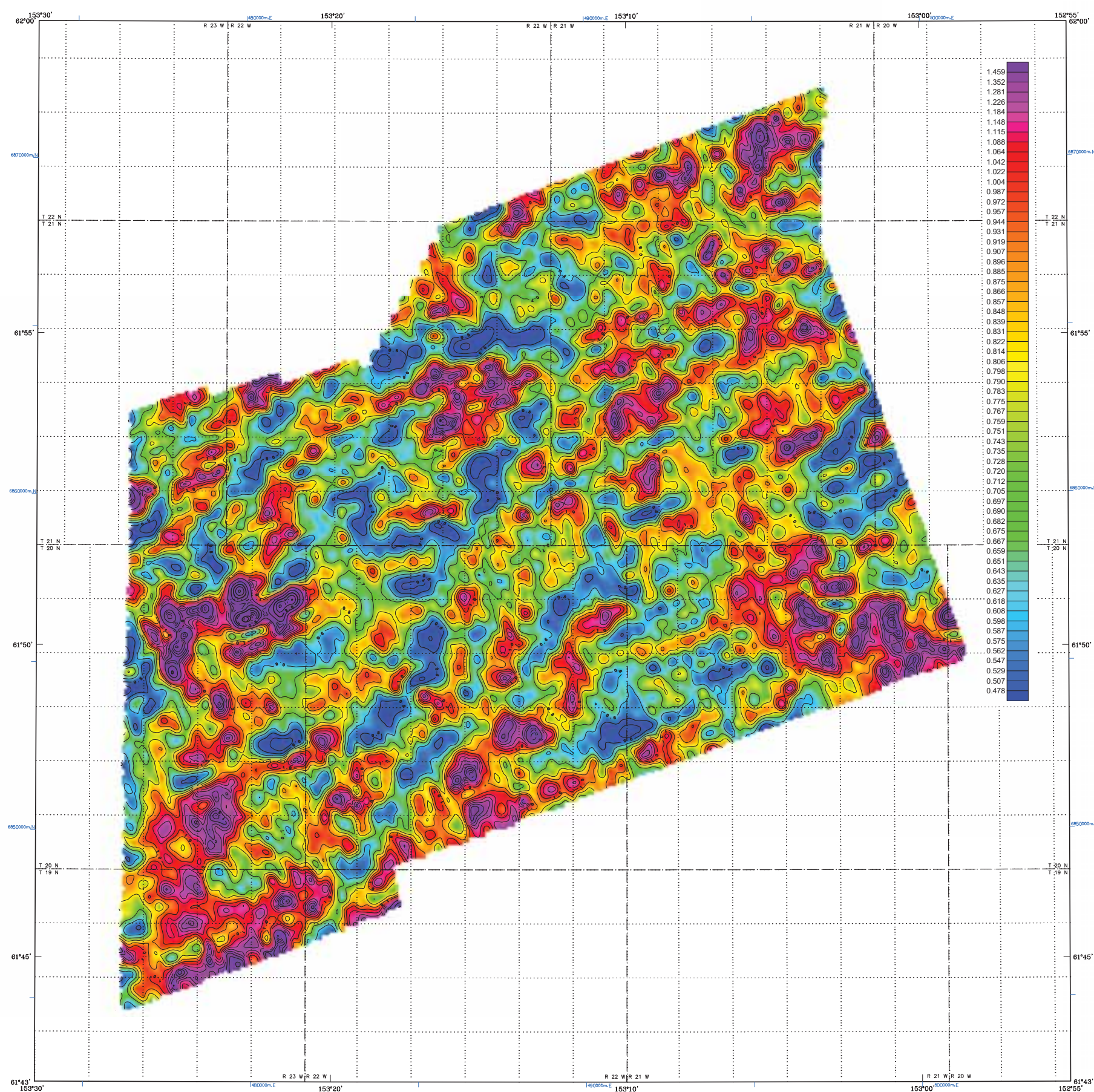

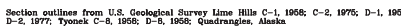

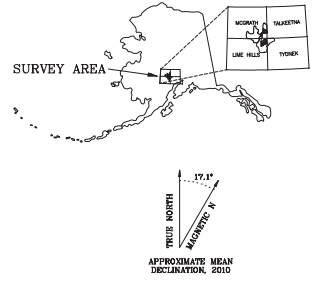

DESCRIPTIVE NOTES

The geophysical data, were acquired with a DIGHEMV
Electromagnetic (EM) system, Radiation Solutions
RS-500 gamma-ray spectrometer and a Fugro

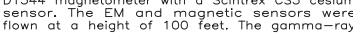

In addition the survey recorded data from rada
and laser altimeters, GPS navigation system
50. Flate

were performed with an $A S-350-B 3$ Squirre
helicopter at a mean terrain clearance

lines with a spacing of a quarter of a mile
Tie lines were flown perpendicular to the flight

A Novatel OEM4-G2L Global Positioning Syste
was used for navigation. The helicopter Dosition
was derived every o 5 seconds using post-fligh

differential positioning to a relative accuracy
better than $5 m$. Flight path positions wer
projected onto the Clarke 1866 (UTM zone

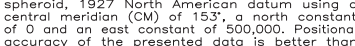

$10 \mathrm{~m}$ with respect to the UTM grid better tha

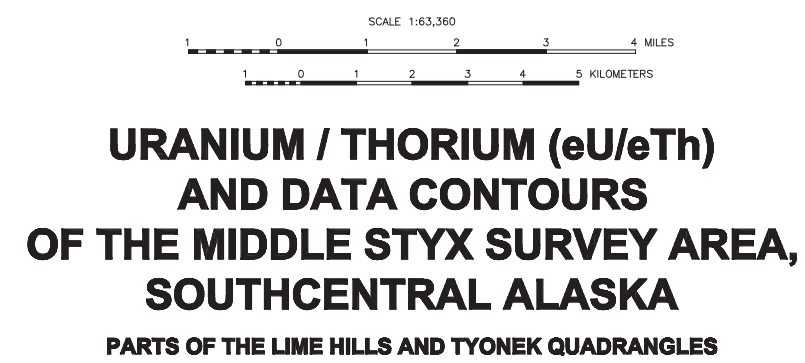

by
Laurel E. Bums, Fugro Arbome Surveys Corp., and Fugro GeoServices, Inc.
2013 RADIOMETRICS

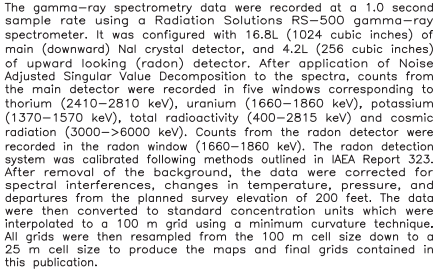

Aiternational Atomic Energy Agency. 1991, Airborne Gammo Ray Spectrometer
URANIUM / THORIUM (eU/eTh)

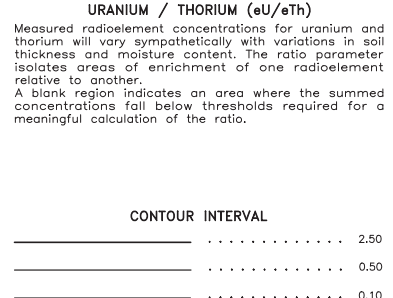

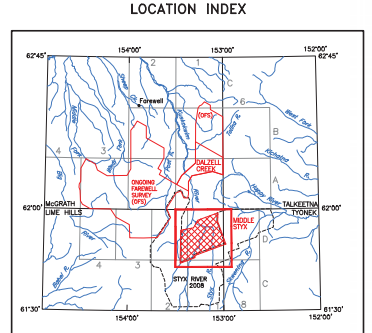

SURVEY HISTORY

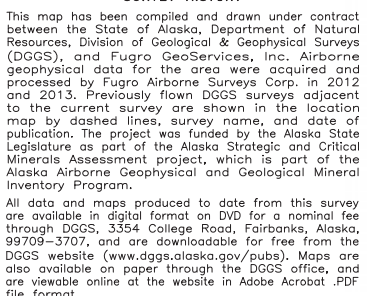




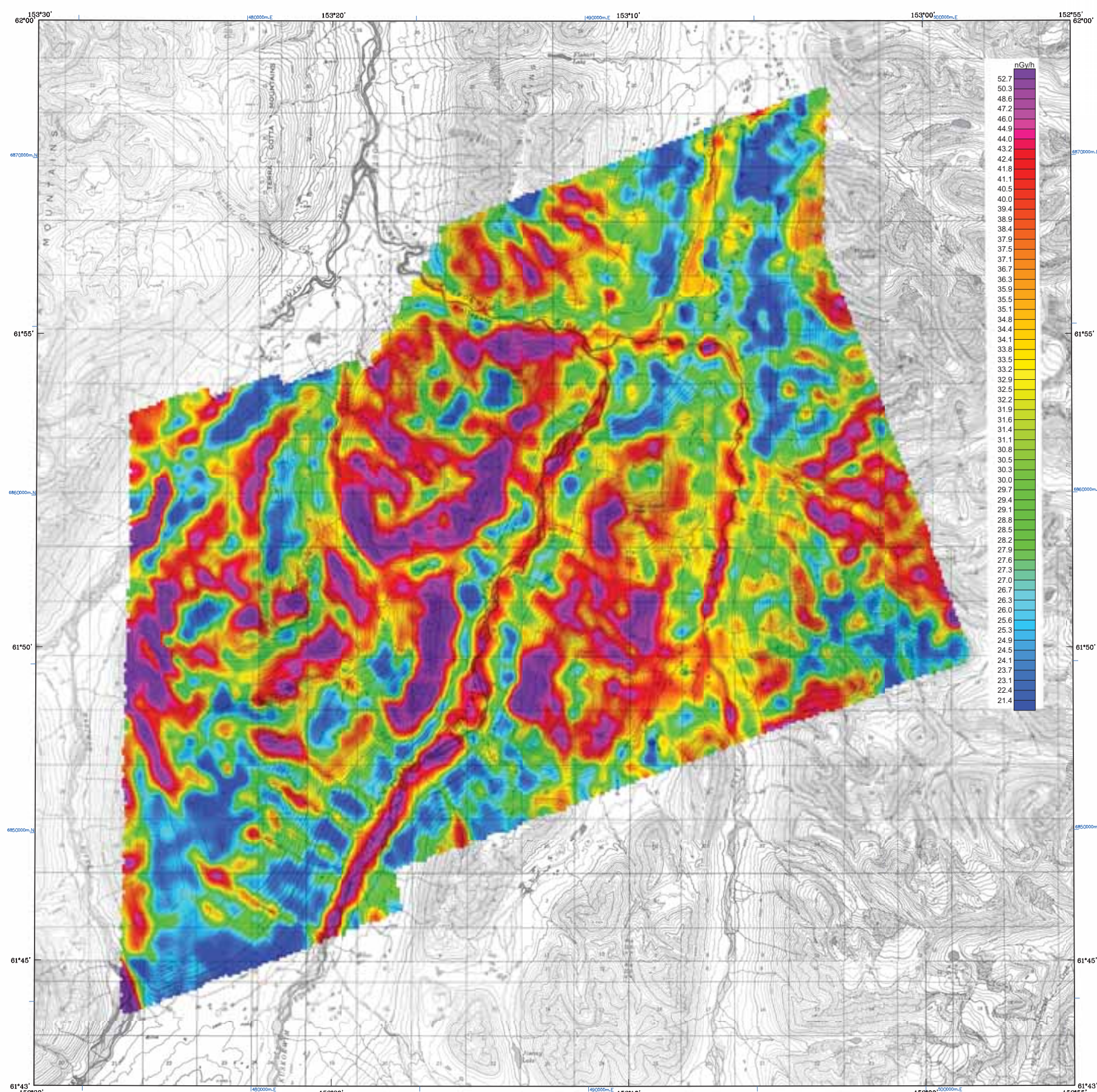

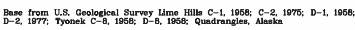

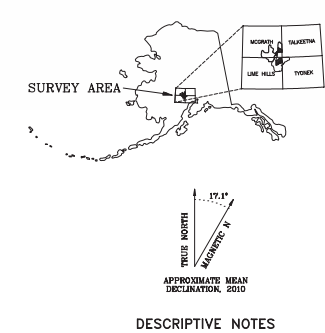

NATURAL AIR ABSORBED DOSE RATE (nGy/h) WITH TOPOGRAPHY OF THE MIDDLE STYX SURVEY AREA, SOUTHCENTRAL ALASKA PARTS OF THE LIME HILLS AND TYONEK QUADRANGLES

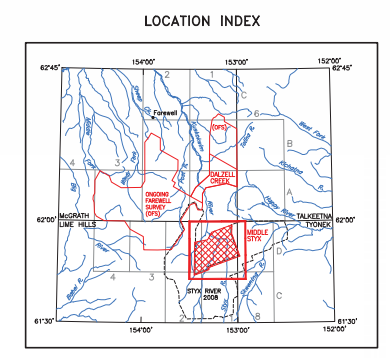

Laurel E. Bums, Fugro Airbome Suveys Corp., and Fugro GeoServices, Inc.
2013 RADIOMETRICS

SURVEY HISTORY

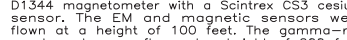

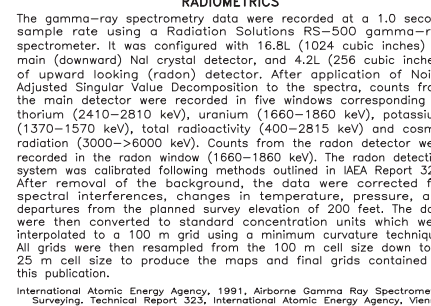




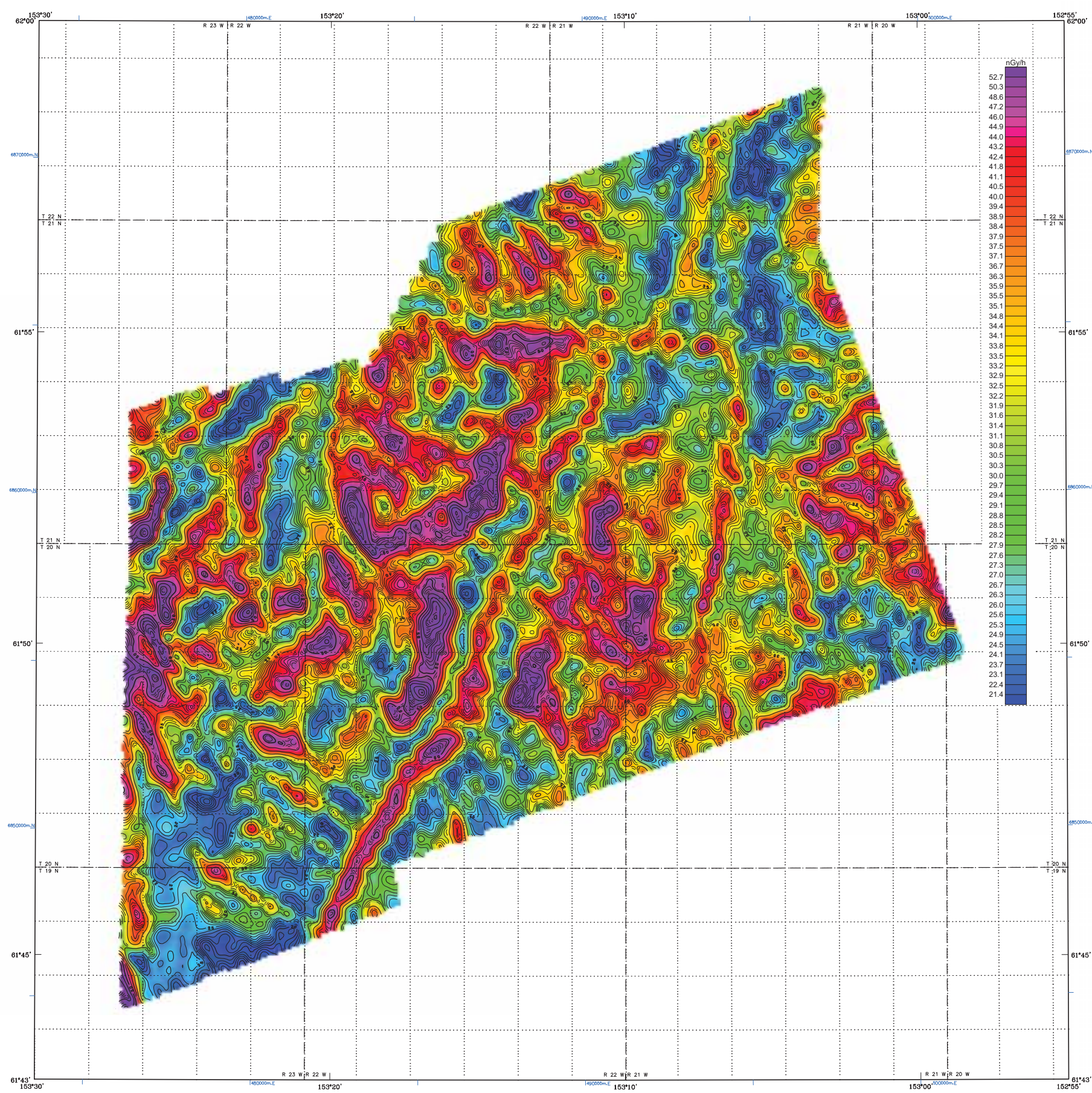

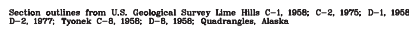

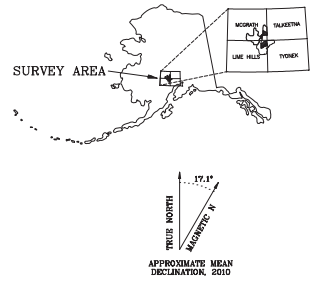

DESCRIPTIVE NOTES

The geophysical data, were acquired with a DIGHEMV
Electromagnetic (EM) system, Radiation Solutions
RS-500 gamma-ray spectrometer and a Fugro

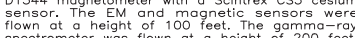

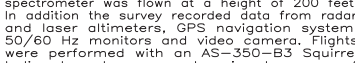

200 feet along $N E-S W\left(70^{\circ}\right)$ survey fligh
lines with a spacing of a quarter of a mile
Tie lines were flown perpendicular to the flight

A Novatel

differential positioning to a relative accuracy
better ta

spheroid, 1927 North American datum using
central meridian (CM) of $153^{\prime}$ a north constan
of

gccuracy of the presented data is better than
$10 \mathrm{~m}$ with respect to the UTM grid
NATURAL AIR ABSORBED DOSE RATE (nGy/h) AND DATA CONTOURS OF THE MIDDLE STYX SURVEY AREA, SOUTHCENTRAL ALASKA

PARTS OF THE LME HILLS AND TYONEK QUADRANGLES

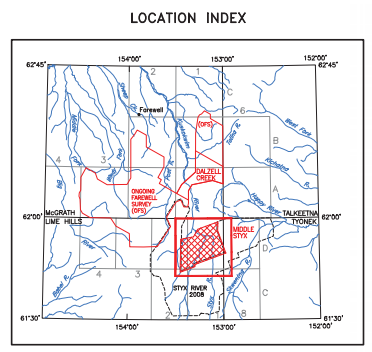

by
Laurel E. Bums, Fugro Arbome Surveys Corp., and Fugro GeoSenvices, Inc.
2013 RADIOMETRICS

SURVEY HISTORY

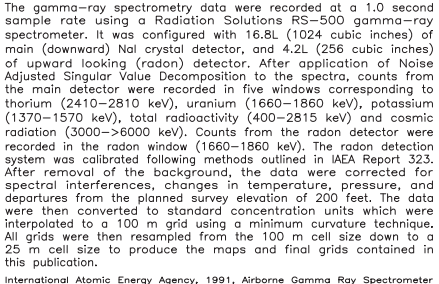

NATURAL AIR ABSORBED DOSE RATE

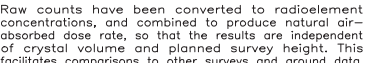

CONTOUR INTERVA

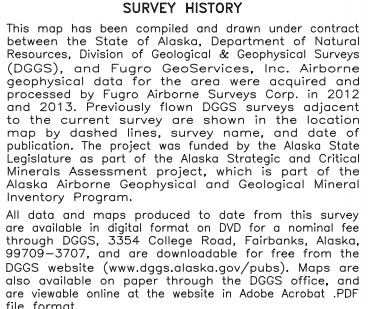




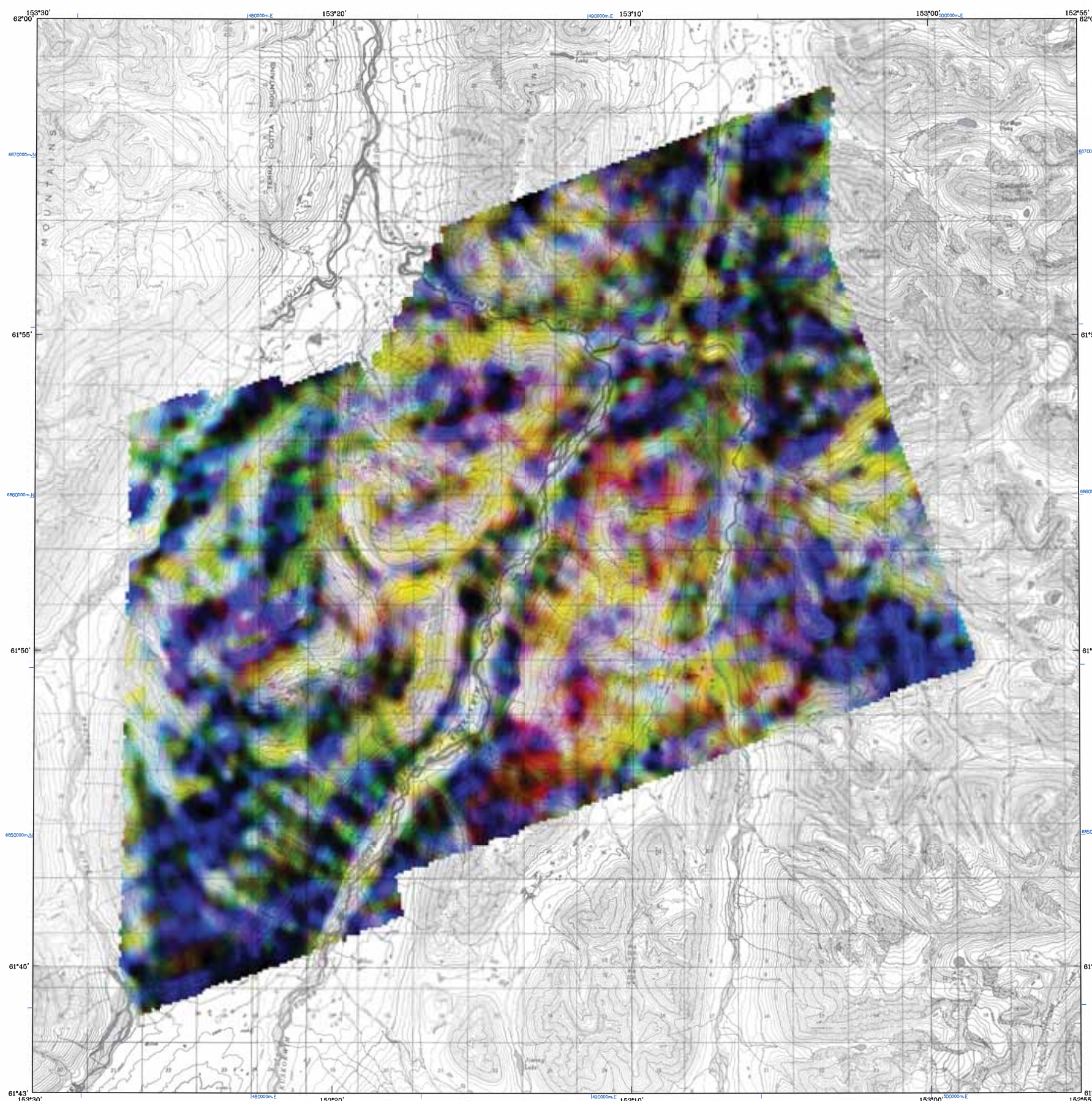

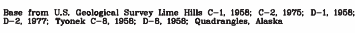
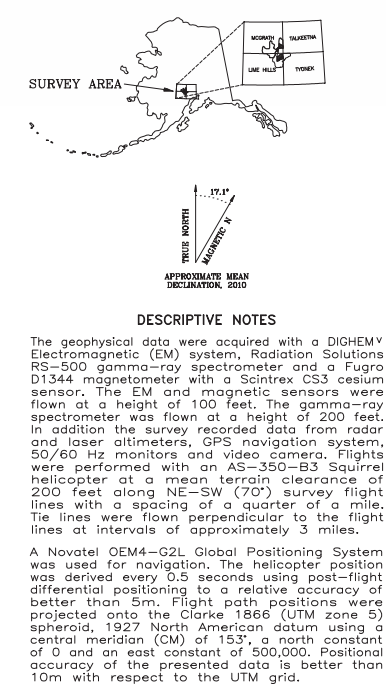

\section{RADIOELEMENT - TERNARY WITH TOPOGRAPHY OF THE MIDDLE STYX SURVEY AREA, SOUTHCENTRAL ALASKA PARTS OF THE LME HILLS AND TYONEK QUADRANGLES} by
Laurel E. Bums, Fugro Arborme Surveys Corp., and Fugro GeoServices, Inc.
2013

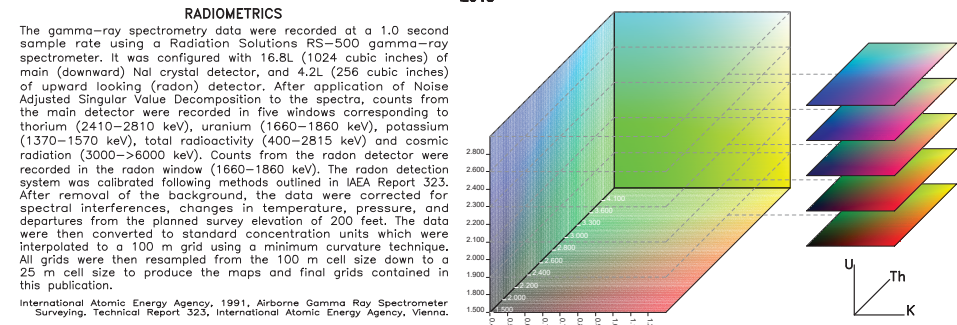

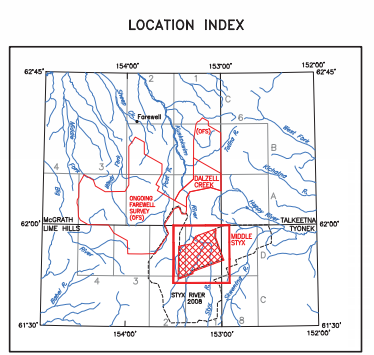

SURVEY HISTORY 